\title{
NBSIR 82-2516
}

\section{Computer Fire Modeling for the Prediction of Flashover}

U.S. DEPARTMENT OF COMMERCE

National Bureau of Standards

National Engineering Laboratory

Center for Fire Research

Washington, DC 20234

May 1982

Prepared for

I.S. Department of Health and Human Services Vashington, DC 20203 



\section{COMPUTER FIRE MODELING FOR THE PREDICTION OF FLASHOVER}

Richard D. Peacock

J. Newton Breese

U.S. DEPARTMENT OF COMMERCE National Bureau of Standards National Engineering Laboratory Center for Fire Research

Washington, DC 20234

May 1982

\section{Prepared for}

U.S. Department of Health and Human Services

Washington, DC 20203

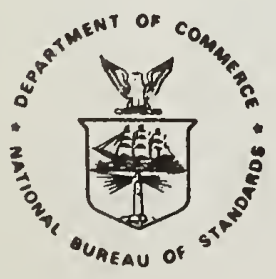

U.S. DEPARTMENT OF COMMERCE, Malcolm Baldrige, Secretary NATIONAL BUREAU OF STANDARDS, Ernest Ambler, Director 

LIST OF FIGURES .................... . . . v

LIST OF TABLES ........................ vi

Abstract ............................ 1

1. INTRODUCTION ....................... 1

2. REVIEW OF PREVIOUS WORK .................... 3

2.1 A Working Definition of Flashover ........ 3

2.1.1 Temperature ............ 3

2.1 .2 Heat Flux ........... 6

2.2 Mathematical Modeling of Fires . . . . . . . 8

2.3 Estimating Room Flashover Potential ......... 10

3. MODEL USED FOR THIS STUDY - ASSUMPTIONS AND

PARAMETERS INVESTIGATED . . . . . . . . . . 12

3.1 Parameters Investigated . . . . . . . . 12

3.1.1 Ventilation Factor Series ......... 14

3.1.2 Aspect Ratio Series ............ 14

3.1 .3 Room Height Series ............ 14

3.1.4 Wall Material Series ........... 15

3.2 Fire Algorithm ............. 15

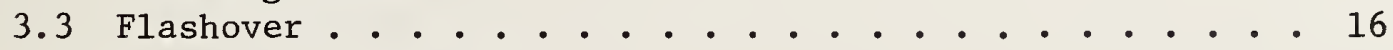

4. COMPUTER RUNS AND RESULTS . . . . . . . . . . 16

5. DISCUSSION OF RESULTS .................. 17

5.1 Effect of Room Ventilation .......... 18

5.2 Effect of Room Geometry ............ 19

5.3 Effect of Room Height . . . . . . . . . 20

5.4 Effect of Wall Lining............ 20

5.5 Comparison with Test Data............. 21

5.6 Comparison with Other Predictions . . . . . . 22

6. USTNG THE MODEL PREDICTIONS TO DETERMINE

MINIMUM FLASHOVER ENERGY . . . . . . . . . . . 23 
T'ABLE OF CONTENTS (continued)

Page

7. CONCLUSIONS, RECOMMENDATIONS AND LIMITATIONS . . . . . . 25

7.1 Limitations of this Study . . . . . . . . . 26

7.2 The Link with Room Furnishings . . . . . . . . . 27

8. ACKNOWLEDGEMENTS . . . . . . . . . . . . . 28

9. REFERENCES . . . . . . . . . . . . . 28

Appendix A . . . . . . . . . . . . . . . 59 
Figure 1. Mathematical Modeling of Fires in an Enclosure . . 33

Figure 2. Basic Room Configuration for Computer Modeling Predictions............... 34

Figure 3. Room Flashover Modeling Prediction for Various Ventilation Factors (Gypsum Wall Lining / $2.4 \mathrm{~m}$ Ceiling Height) . . . . . . . . . . . 35

Figure 4. Room Flashover Modeling Prediction for Various Room Heights (Gypsum Wall Lining / Ventilation Factor, $\mathrm{A}(\mathrm{h}) 1 / 2=5.0$ ) ........... 36

Figure 5. $\mathrm{P}_{\text {height }}$-- Percentage of Minimum Flashover Energy for Rooms With Ceiling Heights Greater Than $2.4 \mathrm{~m}$. . 37

Figure 6. Room Flashover Modeling Prediction for Various Wall Lining Materials (2.4 m Ceiling Height / Ventilation Factor, $\left.A(h)^{1 / 2}=5.0\right)$............. 38

Figure 7. $\mathrm{P}_{\text {wall }}$-- Percentage of Minimum Flashover Energy

for Wall Lining Materials Other Than Gypsum Board . • 39 


\section{LIST OF TABLES}

Page

Table 1. Parameters that Can Be Varied in the Harvard Model . . 40

Table 2. Room and Vent Sizes Investigated . . . . . . . 42

Table 3. Thermal Properties of Room Lining Materials . . . . 43

Table 4. Key to Values Appearing in Tables 5, 6, 7 and 8 . . 44

Table 5. Effect of Vent Size on Time and Energy Needed to

Achieve Flashover ............ 45

Table 6. Effect of Aspect Ratio on Time and Energy Needed

to Achieve Flashover . . . . . . . . . . 54

Table 7. Effect of Room Height on Time and Energy Needed to Achieve Flashover . . . . . . . . . 55

Table 8. Effect of Wall Lining Material on Time and Energy Needed to Achieve Flashover . . . . . . . 56

Table 9. Comparison of Predictions with Full-Scale Fire Tests . 58 
COMPUTER FIRE MODELING FOR THE PREDICTION OF FLASHOVER

\title{
Richard D. Peacock
}

J. Newton Breese

\begin{abstract}
This study presents an initial look at the potential for the use of fire growth models. A technique is presented, based upon numerous fire growth predictions to estimate the minimum energy required to produce temperature levels capable of promoting flashover in a variety of room configurations. The parameters investigated included room size, room ventilation, ceiling height and room lining material. A comparison is presented of the predictions made with available full-scale fire test data and with other predictions. The technique, although needing refinement, shows promise to estimate flashover potential.

Key words: Compartment fires; computers; fire growth; flashover; mathematical models.
\end{abstract}

\section{INTRODUCTION}

Recent advances in computing and mathematical modeling of physical phenomena have led to the development of a number of computer programs for the prediction of the growth of a fire within a room. Owing to the complexity of the problem, many of the models require large computing facilities not always available to the fire safety engineering designer. Until recently, the application of these models has been limited to experiments designed to verify the prediction capabilities of the models. Nonetheless, the successful use of the computer for the prediction of fire phenomena shows great promise for the designer who will be able to anticipate the fire performance of a new building design before construction and without expensive full scale fire testing.

One area of considerable interest is the prediction of flashover, the rapid transition from slow initial fire growth to full room involvement. Since it clearly signals a greatly increased risk to building 
occupants as well as to other building areas not initially involved on the fire, it is a logical criterion for fire safety design of building construction and use.

As a part of the Fire/Life Safety Program at the Center for Fire Research (CFR) at the National Bureau of Standards (NBS), the United States Department of Health and Human Services (HHS) has sponsored a project to investigate the potential of the prediction of the occurrence of flashover as a design criterion for building construction. The operation of any hospital, nursing home, or in some cases, board and care homes involves a degree of risk resulting from the need to maintain storage, laboratories and other areas where the fire potential is significantly more than that of the typical bedroom or similar area. The segregation of these hazardous areas is a key element in facility protection. However, the current treatment of hazardous areas in building codes lumps a wide variety of possible hazards into a two level category of hazardous areas, resulting in mandating requirements for safety that are directed at the worst problem in each level. While the protection of hazardous areas is vital to fire safety, there is currently no rational way to determine what is truly a life threatening hazard or to regulate safeguards appropriate to the true threat.

This report presents the results of the application of one of the computer fire models to the prediction of flashover to enable the designer or regulator to classify the hazard of an area based upon the potential of the space to flash over. By presenting a variety of room configurations, the intent is to provide a design tool to determine the critical energy release rate in a room necessary to produce flashover in terms of room size, shape, ventilation and room lining material. While further work will be needed to extend and refine the approach and relate it to real-world burning rates, the approach presented here provides the basis for the development of proposed adjustments to hazardous area criteria in the Life Safety Code and important professional insight to a critical problem in fire safety. 


\section{REVIEW OF PREVIOUS WORK}

The occurrence of flashover within a room is of considerable interest to the fire protection specialist since it is perhaps the ultimate signal of untenable conditions within the room of fire origin as well as a sign of greatly increased risk to other rooms within the building. A number of experimental studies of full scale fires have been performed that provide an adequate definition of flashover in terms of measurable physical properties. Computer simulations of the growth of a fire within a room are available. A brief review of these efforts is presented below to provide a background for the study presented here.

\subsection{A Working Definition of Flashover}

Visually, flashover has been observed in full-scale fire tests. Quantification of the process in terms of measureable physical parameters, however, is not as easy to obtain. A considerable body of fullscale fire test data studying flashover exists from a variety of sources.

\subsubsection{Temperature}

Harmathy $[1,2]^{1}$ presents a review of compartment fire tests and develops some theoretical predictions for comparison. For a series of fu11-scale compartment burnout tests, he presents average upper gas temperature rises of from $198-959^{\circ} \mathrm{C}\left(356-1725^{\circ} \mathrm{F}\right)$ with an average of $584^{\circ} \mathrm{C}$ for fully developed fires in an enclosure with a surface area of $55 \mathrm{~m}^{2}$.

Heselden [3] and Thomas and Heselden [4] report the results of an experimental study of the behavior of fully-developed fires in single compartments carried out by a number of laboratories. Gas temperatures measured centrally in the compartment a quarter of the height below the ceiling reached an average of $1070-1145^{\circ} \mathrm{C}$ during three different series of tests.

\footnotetext{
Numbers in brackets refer to the literature references listed in section 9 at the end of this report.
} 
Hagglund, et a1. [5] report that flashover defined by them as flames exiting the doorway was experimentally observed when the gas temperature about $10 \mathrm{~mm}$ below the ceiling reached $600^{\circ} \mathrm{C}$. Babrauskas [6] applied this criterion to a series of full-scale mattress fires. Of the ten mattresses tested, only two exhibited potential to flashover the test room. These two mattress fires led to maximum gas temperatures of $938^{\circ} \mathrm{C}$ and $1055^{\circ} \mathrm{C}\left(1720^{\circ} \mathrm{F}\right.$ and $\left.1931^{\circ} \mathrm{F}\right)$.

Fang [7] reported on experiments conducted in a full-scale enclosure at NBS. An average upper room temperature ranging from $450^{\circ} \mathrm{C}$ to $650^{\circ} \mathrm{C}$ $\left(840^{\circ} \mathrm{F}\right.$ to $1200^{\circ} \mathrm{F}$ ) provided a level of radiation transfer sufficient to result in the ignition of paper flashover indicators at floor level in the compartment. The average upper room gas temperature necessary for spontaneous ignition of newsprint was $540 \pm 40^{\circ} \mathrm{C}\left(1004 \pm 70^{\circ} \mathrm{F}\right)$. It should be noted that this average included low temperatures at the midheight of the room and that temperatures measured $25 \mathrm{~mm}$ ( $1 \mathrm{in}$ ) below the ceiling in his test series almost always exceeded $600^{\circ} \mathrm{C}\left(1110^{\circ} \mathrm{F}\right)$.

Budnick and Klein [8-11] performed several series of tests to study the fire safety of mobile homes. During tests in the living room of a mobile home, ignition of paper flashover indicators was observed with upper room temperatures ranging from $673^{\circ} \mathrm{C}$ to $771^{\circ} \mathrm{C}\left(1240^{\circ} \mathrm{F}\right.$ to $\left.1420^{\circ} \mathrm{F}\right)$. For tests where full room involvement was not noted, maximum upper room temperatures ranged from $311^{\circ} \mathrm{C}$ to $520^{\circ} \mathrm{C}\left(592^{\circ} \mathrm{F}\right.$ to $\left.968^{\circ} \mathrm{C}\right)$ [8]. Results of tests conducted in the master bedroom of a typically constructed single-width mobile home indicated peak temperatures ranging from $300^{\circ} \mathrm{C}$ to $375^{\circ} \mathrm{C}\left(572^{\circ} \mathrm{F}\right.$ to $\left.702^{\circ} \mathrm{F}\right)$ for tests where flashover was not observed and temperatures ranging from $634^{\circ} \mathrm{C}$ to $734^{\circ} \mathrm{C}\left(1173^{\circ} \mathrm{F}\right.$ to $\left.1353^{\circ} \mathrm{F}\right)$ at flashover. Al1 temperatures reported were measured $25 \mathrm{~mm}$ ( $1 \mathrm{in}$ ) below the ceiling in the center of the bedroom [9].

Lee and Breese [12] report ignition of newsprint on the floor as a flashover indicator in full scale and $1 / 4$ scale tests of submarine hull insulation at room air and doorway air temperatures of at least $650^{\circ} \mathrm{C}$ 
$\left(1200^{\circ} \mathrm{F}\right)$ and $550^{\circ} \mathrm{C}\left(1020^{\circ} \mathrm{F}\right)$ respectively. For tests where flashover was not obtained, these temperatures reached a maximum of $427^{\circ} \mathrm{C}\left(801^{\circ} \mathrm{F}\right)$ and $324^{\circ} \mathrm{C}\left(615^{\circ} \mathrm{F}\right)$. They note, however, that ignition of newsprint or some designated minimum doorway or interior air temperatures are only rough indicators of flashover because of the variation in the thermal and physical properties of crumpled newsprint, the non-uniform distribution of temperatures throughout the compartment, and the differences between tests of the combined thermal radiation from the smoke, the hot air and the heated surfaces. The hot air inside the compartment usually became well mixed by the time it exited through the doorway. Thus, they concluded that doorway temperatures may be more reliable flashover indicators than interior air temperatures.

Babrauskas [13] observed flashover during a test of a urethane foam block chair resulting in maximum temperatures over $800^{\circ} \mathrm{C}\left(1470^{\circ} \mathrm{F}\right)$. For other tests of upholstered chairs that did not achieve flashover, temperatures were below $600^{\circ} \mathrm{C}\left(1110^{\circ} \mathrm{F}\right)$.

Fang and Breese [14] observed ignition of paper flashover indicators at floor level with an average upper room gas temperature of $706 \pm 92^{\circ} \mathrm{C}$ with a $90 \%$ confidence level for a series of sixteen full-scale fire tests of residential basement rooms.

To assess the relative fire risk of cellular plastic materials as compared to wood for use in furniture Quintiere and McCaffrey [15,16] studied the burning of wood and plastic cribs in a room. They found a gap between lower temperature fires (ceiling layer gas temperature less than $450^{\circ} \mathrm{C}$ ) and high temperature fires (ceiling layer gas temperature greater than $600^{\circ} \mathrm{C}$ ). They measured the potential for flashover from the fact that cellulose filter paper tell-tabs did indeed ignite or were destroyed in the five cases (out of sixteen) involving high gas temperatures. 
Thomas [17] describes the calculation of the rate of heat release required to cause flashover in a compartment. He presents a simple model of flashover in a room and with it studies the influence of wall lining materials and thermal feedback to the burning items. He predicts a temperature rise of $520^{\circ} \mathrm{C}\left(936^{\circ} \mathrm{F}\right)$ and a black body radiation level of $22 \mathrm{~kW} / \mathrm{m}^{-2}$ to an ambient surface away from the neighborhood of a burning wood fuel at the predicted critical heat release rate necessary to cause flashover.

\subsubsection{Heat F1ux}

Heat flux to exposed items within the fire room has also been used as a criterion for the definition of flashover. Parker and Lee [18] have suggested using a criterion level of $20 \mathrm{~kW} / \mathrm{m}^{2}$ as the heat flux at floor level at which cellulosic fuels in the lower part of the room are likely to ignite.

A range of materials tested for ignition time and fluxes are reported by Babrauskas [6]. For some common materials, the following ignition fluxes are given for a 60-second exposure:

$$
\text { F1ux }\left(\mathrm{kW} / \mathrm{m}^{2}\right)
$$

$\begin{array}{lcc} & \text { Piloted } & \text { Unpiloted } \\ \text { Newspaper Want Ads } & 46 & 48 \\ \text { Box Cardboard } & 33 & 43 \\ \text { Polyurethane Foam } & 19 & --\end{array}$

The unpiloted values are considered more appropriate for determination of full room involvement since ignition at considerable distance from the flames is involved. A value of $20 \mathrm{~kW} / \mathrm{m}^{2}$ represents, according to Smith [6,19], an unpiloted ignition time of approximately 180 seconds for box cardboard and is close to an ultimate asymptotic value. 
Fang [7] found in a series of room burns that strips of newsprint placed at floor level ignited at fluxes of 17 to $25 \mathrm{~kW} / \mathrm{m}^{2}$ while $6.4 \mathrm{~mm}$ ( $1 / 4$ in) thick fir plywood ignited at 21 to $33 \mathrm{~kW} / \mathrm{m}^{2}$.

Budnick [8] found that, for tests in which flashover occurred, the minimum total incident heat flux at the center of the floor was $15 \mathrm{~kW} / \mathrm{m}^{2}$.

Lee and Breese [12] report average heat fluxes at floor level of 17 to $30 \mathrm{~kW} / \mathrm{m}^{2}$ at flashover for full-scale tests of submarine compartments.

Fang and Breese [14] found good agreement between the time to ignition of newsprint flashover indicators and the time at which the incident heat flux measured at the center of the floor in the burn room reached a level of $20 \mathrm{~kW} / \mathrm{m}^{2}$ during tests in a basement recreation room.

A nominal incident floor heat flux of $20 \mathrm{~kW} / \mathrm{m}^{2}$ may be used as an indicator of the potential onset of flashover according to Quintiere and McCaffrey [15]. Ignition of filter paper flashover indicators was observed at a minimum of $17.7 \mathrm{~kW} / \mathrm{m}^{2}$ applied for roughly 200 seconds or more. Under more controlled laboratory conditions, with radiant exposure to the same target configuration, the paper charred black at $25 \mathrm{~kW} / \mathrm{m}^{2}$ and ripped at 120 seconds, but only decomposed to a brown color under $15 \mathrm{~kW} / \mathrm{m}^{2}$.

While the researchers used different definitions for the onset of flashover, fairly good agreement was evident from a number of researchers on two criteria for the onset of flashover. A working definition, for the purpose of defining flashover in terms of measureable physical parameters would be:

Upper Gas Temperature $\geq 600^{\circ} \mathrm{C}$, or
Heat Flux at Floor Level $\geq 20 \mathrm{~kW} / \mathrm{m}^{2}$. 


\subsection{Mathematical Modeling of Fires}

Considerable effort and resources have been directed at the mathematical modeling of the growth of a fire within a room from ignition to flashover. Friedman [20] and Levine [21] present overviews of the accomplishments to date. In the mid $1960^{\prime} \mathrm{s}$, Thomas [22] developed an approximate theory of the growth to flashover of fires in compartments. Since the late $1960^{\prime} \mathrm{s}$, researchers have successfully utilized the digital computer for the prediction of the various processes that take place during the growth of a fire [23]. More recently, more sophisticated models have evolved which have considered such effects as: ventilation, growth of the fire, energy feedback to the fire, turbulence, heat loss to the ceiling, and radiation induced ignitions of secondary objects within the room [20]. The Japanese Bullding Research Institute has used computer modeling to study radiative ignition and the spread of fire on walls and other surfaces [24,25]. Emmons and Mitler [26-31] have developed a room fire model to predict the response of a room to a fire within the room. Pape, et al [32-39], have studied the burning of furniture items within a room by computer modeling. They present burning rate curves for typical furniture items [32]. Quintiere [40] and McCaffrey $[15,41]$ have developed a series of quasi-steady state models. Cooper [42] has applied computer modeling to estimate the time available for safe egress from a fire by coupling the detection of fire with a fire growth model to estimate untenable conditions within the room.

Certainly, one of the most comprehensive models is the Harvard University Computer Fire Code V developed by Emmons and Mitler [26-31] This version of the mathematical model permits the computation of the development of a fire in a vented enclosure. The fire can be one of three kinds: a growing fire (ignited at a point), a pool fire, or a burner fire. The room may have up to five vents. Mass flows through the vents are calculated; species concentrations $\left(\mathrm{CO}, \mathrm{CO}_{2}, \mathrm{H}_{2} \mathrm{O}, \mathrm{O}_{2}\right.$, 
soot) are found for the hot layer, as well as its depth, temperature, and absorptivity. The surface temperatures of up to four objects (besides the original one) can be found, and they may ignite either by piloted ignition, by radiation, or by contact with a (growing) flame. The calculation can be carried forward as far as desired. For a limited fuel mass, this means through flashover, burnout, and cooldown. No provision is yet made for the burning of walls or ceiling.

Figure 1 is an illustration of the processes occurring in a fire in a compartment with an opening in it [21,26]. The fire over the burning object generates a plume of hot gas that entrains air, $\stackrel{M}{i p}_{0}$ from the lower layer, and adds a flux of hot, partly unburned gas, $M_{p}$, to the hot ceiling layer. Early in the fire, before the ceiling layer has grown below the doorway height, $\mathrm{H}_{i}$, air flows out the doorway to make room for the hot, lower density gas in the ceiling layer. Later, for a short time, both hot ceiling layer gas and air flow out the doorway; then as the ceiling layer approaches the thickness $h_{L}$, ceiling layer gas flows out and outside air flows in. At the neutral plane, the pressure outside and inside the room are equal. Buoyancy forces cause the pressure above the neutral plane inside the room to be greater than the outside pressure, and lower than the outside pressure below the neutral plane.

The outflow of the room ceiling layer gases is of key concern to the safety of the rest of the structure, since this is the source of smoke and toxic gases. The other rooms in the structure are generally made untenable by smoke or toxicity before they are untenable due to heat [43].

As figure 1 indicates, many processes occurring within the room interact. Thermal radiation from the fire, the hot ceiling layer, and the upper walls and ceiling affect the combustion rate (of the outside surfaces) of the burning object, and also heat up other objects in the room, shown here as a "target", until they may eventually ignite. If 
the flame is spreading, the rate of flame spread, as well as the rate of burning of already ignited surfaces, will be affected by the heating due to this radiation.

The plume above the fire and its entrainment of lower layer air is, of course, affected by the burning rate of the fire, which in turn is affected by the thermal radiation, the reduction of the oxygen content of the lower layer air caused by mixing between the two layers (not shown in figure 1 ), and drafts due to the incoming cooler air $\stackrel{\circ}{M}_{i}$. The upper layer gases are cooled by convective and radiative heat transfer to the ceiling and upper walls, and this cooling can have a significant influence on the temperature of the upper layer, its radiation, and hence the growth rate of the fire.

Since the mathematical model must reproduce the interactions described above, where each process is affected by the other processes, it consists of a set of mathematical equations that must be solved simultaneously, usually interactively, and is only practically done on a computer.

\subsection{Estimating Room Flashover Potential}

Two approaches have been taken to estimate the onset of flashover within a room. Babrauskas [44] developed a simple combustion model with a flashover criterion of $\Delta \mathrm{T}=575^{\circ} \mathrm{C}$ and compared the results of the predictions using the model with experimental results. He provides a simple rule to estimate the minimum heat release rate to produce flashover:

$$
\dot{q}=0.6 \mathrm{~A}(\mathrm{~h})^{1 / 2}
$$

where $\dot{q}$ is the estimated rate of heat release in MW, A is the door area in $\mathrm{m}^{2}$ and $\mathrm{h}$ is the door height in $\mathrm{m}$. The $\mathrm{A}(\mathrm{h})^{1 / 2}$ factor is usually 
called the "ventilation factor." He reports adequate agreement with experimental data with $2 / 3$ of the data studied falling between $\dot{q}=$ $0.45 \mathrm{~A}(\mathrm{~h})^{1 / 2}$ and $\dot{\mathrm{q}}=1.05 \mathrm{~A}(\mathrm{~h})^{1 / 2}$.

McCaffrey, Quintiere and Harkelroad [45] performed a regression analysis to provide a correlation to predict gas temperature. Using data from over 100 experiments, they found a correlation based on two dimensionless quantities:

$$
\Delta T=480\left[\frac{\dot{q}}{\sqrt{g C_{p} \rho_{o} T_{o} A \sqrt{H}}}\right]^{2 / 3} \cdot\left[\frac{h_{k} A_{w}}{\sqrt{g C_{p} \rho_{o} A \sqrt{H}}}\right]^{-1 / 3} \quad{ }^{\circ} \mathrm{C}
$$

where $\Delta \mathrm{T}$ is the temperature rise relative to ambient in ${ }^{\circ} \mathrm{C}, \mathrm{h}_{\mathrm{K}}$ is the effective heat transfer coefficient to ceilings/walls, $A_{W}$ is the effective surface area for heat transfer including door area $g$ is the gravitational constant, $\mathrm{C}_{\mathrm{p}}$ is the specific heat of gas, $\rho_{0}$ is the ambient gas density, and $T_{0}$ is the initial ambient absolute temperature. A means to calculate the effective heat transfer coefficient, $h_{k}$ is given in reference [39]. They report a multiple correlation coefficient of 0.959 or 0.947 depending upon whether the floor is included in the calculation of the wall area and the effective heat transfer coefficient.

By substituting typical values for $\mathrm{C}_{\mathrm{p}}, \rho_{\mathrm{o}}, \mathrm{T}_{\mathrm{o}}$ and a flashover criterion of $\Delta \mathrm{T}=500^{\circ} \mathrm{C}$, the above equation can be reduced to

$$
\dot{q}=0.61\left[h_{k} A_{w} A(h)^{1 / 2}\right]^{1 / 2}
$$

where $\dot{q}$ is in MW, $A_{w}$ and $A$ are in $m^{2}, h$ is in $m$ and $h_{k}$ is in $k W / m^{2} K^{-1}$.

Thomas [17] obtained an equation to predict the minimum flashover energy by adjusting a simple model of a room fire with an "effective calorific value" for the heat of combustion of the burning material of approximately $70 \%$ of the actual value. In our notation, he predicts 


$$
\dot{q}=0.0078 \mathrm{~A}_{\mathrm{W}}+0.378 \mathrm{~A}(\mathrm{~h})^{1 / 2}
$$

where $\dot{q}$ is in $M W, A_{W}$ and $A$ are on $m^{2}$ and $h$ is in $m$.

\section{MODEL USED FOR THIS STUDY - ASSUMPTIONS AND PARAMETERS INVESTIGATED}

Of all the computer fire models available, certainly one of the most comprehensive is the Harvard Fire Code V [26-31]. The physical basis of the model has been described in detail by Mitler [26]. Instructions are available for its use [27]. The Harvard model was chosen for use in this study for several reasons:

- as one of the most advanced models, variation of many parameters is possible;

- the prediction capabilities follow the course of the fire from ignition through flashover and to extinguishment; and

- It was avallable and working on computers at the National Bureau of Standards.

The model allows variation of up to 50 parameters describing the physical and thermal properties of the room, the venting from the room, the objects within the room and the initial fire involving one or more of the objects. Table 1 presents the various parameters that may be changed through appropriate data input.

\subsection{Parameters Investigated}

Obviously, a systematic variation of all the parameters in table 1 would be a monumental undertaking, involving up to $3 \times 10^{64}$ computer runs. However, a smaller number of variables are most important to the engineer designing for fire protection. For this initial study, the following parameters were investigated: 
- room size (length, width and ceiling helght);

- door/vent size (width, height and placement of doors and windows);

- room lining materials (physical and thermal properties); and

- fire size (rate of heat release, maximum fire size).

Since the object of this investigation was to determine the minimum predicted fire size necessary to achieve flashover within a given room configuration, this led to four series of computer runs:

- a ventilation factor series (variation of the size of vent openings for different rooms);

- an aspect ratio series (variation of the length and width of a single room);

- a room height series (variation of the ceiling height of a single room); and

- a wall material series (variation of the thickness and thermal properties of the wall lining).

F1gure 2 illustrates the basic room configuration. Each one of these series of computer runs is described in detail below. 


\subsubsection{Ventilation Factor Series}

During this series of computer runs, the largest number of runs, nine different rooms sizes and eleven different vent sizes were investigated. Table 2 describes the room and vent sizes. Rooms as small as $1.8 \mathrm{~m} \times 1.8 \mathrm{~m}(6 \times 6 \mathrm{ft})$ and as large as $8.5 \mathrm{~m} \times 12.8 \mathrm{~m}$ (28 $\times 42 \mathrm{ft})$ were included. Room vent size ranged from $10 \%$ to $100 \%$ of the length of the short wall plus a "standard door", $0.76 \mathrm{~m}$ (30 in) in width. Ceiling height and door height were held constant at $2.4 \mathrm{~m}(8 \mathrm{ft}$ ) and $2.03 \mathrm{~m}$ $(6.6 \mathrm{ft})$ respectively. The wall lining material was gypsum wallboard, $12.7 \mathrm{~mm}$ (1/2 in) in thickness.

\subsubsection{Aspect Ratio Series}

For this series, three room sizes studied in the ventilation factor series were chosen - total room surface areas of $48 \mathrm{~m}^{2}, 131 \mathrm{~m}^{2}$ and $323 \mathrm{~m}^{2}$ (520 $\mathrm{ft}^{2}, 1410 \mathrm{ft}^{2}$, and $3480 \mathrm{ft}{ }^{2}$ ) - and the ratio of room length to room width was varied from 1 to 16 . This ratio is referred to as the "aspect ratio" for the room. Besides maintaining a constant total room surface area for a given series of runs, the ceiling height was held constant at $2.4 \mathrm{~m}$ ( $8 \mathrm{ft}$ ); and the vent size was held constant at $1.73 \mathrm{~m} \times 2.03 \mathrm{~m}$ $(5.7 \mathrm{ft} \times 6.6 \mathrm{ft})$. Gypsum wallboard, $12.7 \mathrm{~mm}(1 / 2 \mathrm{in})$ thick, lined the rooms.

\subsubsection{Room Height Series}

The same three rooms used for the aspect ratio series $\left(48 \mathrm{~m}^{2}\right.$, $131 \mathrm{~m}^{2}$ and $323 \mathrm{~m}^{2}$ ) were further studied by varying the ceiling height within the room from $2.4 \mathrm{~m}$ (8 ft) to $12.2 \mathrm{~m}$ (40 ft). The aspect ratio was 1.5 and the vent size was $1.73 \mathrm{~m} \times 2.03 \mathrm{~m}(5.7 \mathrm{ft} \times 6.6 \mathrm{ft}$ ) as before. Similarly, gypsum wallboard was used as the wall lining. 


\subsubsection{Wall Material Series}

The properties of several wall lining materials were input for the three rooms as well. The materials investigated were:

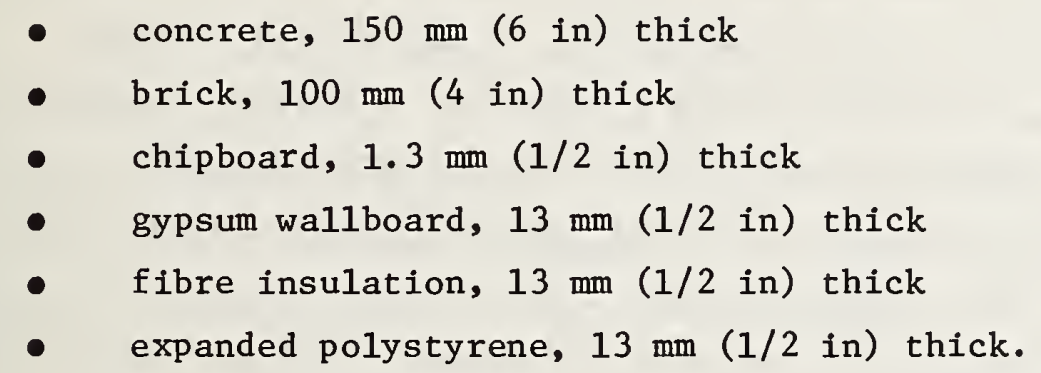

Thermal properties of the lining materials are given in table 3 . Room size, vent size, aspect ratio, and ceiling height were held constant as before. The models do not however, have the capability to predict the behavior of combustible wall linings. Thus, only comparisons of the effect of different heat transfer properties are possible.

\section{2 Fire Algorithm}

For modeling purposes, a fire is described as a time varying source of heat generation within the room. The physics which specify how the rate of heat release of the fire changes is, unfortunately, very complex. However, in the simplest case, a fire which is of a constant heat output is the most severe, and thus appropriate for this study to predict the minimum fire size necessary to produce flashover.

In the Harvard model, this is simulated by a gas burner algorithm which builds to a maximum value in a short period of time after ignition. The buildup to a maximum value is necessary for the numerical solution techniques used in the model to converge to a solution. 


\subsection{F1ashover}

Each computer run must have an end point at which calculation stops. For these series, the end point of the calculations was flashover as evidenced by an upper gas layer temperature rise of $500^{\circ} \mathrm{C}$ above room temperature. While this chosen value is lower than the typical value of $600^{\circ} \mathrm{C}$ (a rise of $573^{\circ} \mathrm{C}$ above room temperature), it was chosen for two reasons: 1) a somewhat lower limit would incorporate a margin of safety into the calculations, and 2) it would allow a more valid comparison to the predictions of McCaffrey, et al [39] and Thomas [17], who used this limit in their calculations. Additionally, a burning time limit of 15 minutes was placed on the calculations. The 15 minute limit was chosen as a reasonable "worst case" time necessary for appropriate safety actions such as evacuation or closing of protective doors.

\section{Computer Runs and Results}

A total of four hundred forty computer runs were made to gain data for the four series of investigations. Since the computer program contains initial values for all of the parameters used, the only data cards read by the program are those which override the initial values in order to tailor the model to a specific design. The initial values built into the program were determined from a series of seven thoroughly instrumented full scale fires [26]. Thus, they represent values which provide "best agreement" between prediction and experiment. For the tests that were run, the changes made were for room dimensions, objects (e.g. gas burner, flashover indicator) in the room, vent dimensions and position, and wall lining material. The program asks for the information in "blocks". First a series of code numbers, representing which information is to be changed, are entered. These numbers are followed by a blank card and the values with which the initial conditions are to be replaced. 
As you can see in the listing of the typical set of data cards in Appendix $A$, the physical room characteristics are described in the block of cards from card 20 through 28, object 1 (the gas burner) is described in the block of cards from 29 through 37, the gas burner fire algorithm in the block from 38 through 47 , and so on.

Appendix A also has a listing of the output produced using the data cards in the appendix. The output begins with a summary of all the values of the parameters at the time of program execution. The summary is followed by the output listing of the values of all the variables examined by the program. Of particular interest are the variables ZKLZZ from $R O O M=1$ and TEOZZ from OBJ=1. ZKLZZ is the average temperature (K) of the upper gas layer. This temperature is used to decide if flashover has been reached. TEOZZ is the energy output of the gas burner (W). It is a negative number because it represents the amount of heat being given off by the burner.

The listing of the variables is produced at $\mathrm{T}=2.000$ seconds and at multiples of the output interval (data card 85) until the maximum time (data card 86) or flashover is reached. In the example, flashover is reached at $\mathrm{T}=558.00$ seconds, the average upper gas temperature (ZKLZZ) is $800.13 \mathrm{~K}$ and the energy output of the burner is $4.4276 \mathrm{MW}$.

Four hundred forty sets of data cards and corresponding computer output were produced. The results of the tests are summarized in tables 4 through 8 .

\section{DISCUSSION OF RESULTS}

The data presented in tables 4-8 represent the minimum energy levels that were predicted to produce flashover for the various room configurations studied. Table 5 shows the effect of room ventilation 
(door and window openings) on the minimum energy necessary for flashover for different size rooms with gypsum wallboard lining and a $2.4 \mathrm{~m}$ ( $8 \mathrm{ft}$ ) ceiling height. Table 6 shows the effect of the room length to width ratio on the minimum flashover energy. Room ceiling height and wall lining material effects are presented in tables 7 and 8 , respectively.

\subsection{Effect of Room Ventilation}

Figure 3 shows only the predicted minimum flashover energy extracted from tables 5 and 6 for the six different size rooms with a length to width ratio of 1.5. The curves drawn for each room size were placed so as to represent a minimum energy level curve for the room size. The room opening size is expressed in terms of the "ventilation factor":

$$
A(h)^{1 / 2}
$$

where $A$ is the area of the opening and $h$ is the height of the opening. For room sizes ranging from $2.4 \mathrm{~m} \mathrm{x} 3.7 \mathrm{~m}(8 \times 12 \mathrm{ft})$ to $8.5 \mathrm{~m} \times 12.8 \mathrm{~m}$ (28 $\times 42 \mathrm{ft}$ ), a ten-fold change in the ventilation factor resulted in only a 25 to 100 percent change in the minimum rate of heat release. The following table shows the effect of the increased opening sizes:

Increase in Minimum Energy Required for Flashover for a Ten-Fold Increase in $A(h) 1 / 2$

\begin{tabular}{|c|c|c|c|}
\hline $\begin{array}{c}\text { Room Size } \\
\text { (m) }\end{array}$ & $\begin{array}{c}\text { Wa } 11 \text { Area } \\
\left(\mathrm{m}^{2}\right)\end{array}$ & $\begin{array}{l}\text { Minimum } \\
\text { Range } \\
\text { (MW) }\end{array}$ & $\begin{array}{l}\text { Flashover Energy } \\
\text { Percent Increase }\end{array}$ \\
\hline $2.4 \times 3.7$ & 48 & $0.74-1.48$ & 100 \\
\hline $3.7 \times 4.9$ & 85 & $0.98-1.97$ & 101 \\
\hline $4.9 \times 7.3$ & 131 & $1.72-2.46$ & 43 \\
\hline $6.1 \times 9.1$ & 186 & $2.21-3.20$ & 45 \\
\hline $7.3 \times 11.0$ & 250 & $2.95-4.18$ & 42 \\
\hline $8.5 \times 12.8$ & 323 & $3.94-4.92$ & 25 \\
\hline
\end{tabular}


For larger rooms with small openings, the fires are of sufficient size that attainment of flashover is difficult due to insufficient oxygen early in the fire buildup. Proportionally larger fires are thus required to reach the $800 \mathrm{~K}$ criterion for flashover at the small opening sizes.

\subsection{Effect of Room Geometry}

Not surprisingly, changing the room length to width ratio (the "Aspect Ratio") had little effect on the energy required for flashover as predicted by the model. Table 6 shows the results of the runs. As a zone model, the prediction of the properties of the upper gas layer are based upon the assumption that the entire layer is well mixed and of uniform properties throughout. Thus, the only effect accounted for in the prediction are changes in view factors for radiative heat transfer. Effects that may be more significant in long, narrow hallways such as (1) the flow of gases from one end of the room to the other or (2) buildup of heat at one end of the room, are not accounted for in the mode1.

The lack of effect from changing the aspect ratio does simplify the resulting predictions. The curves in figure 3 are presented based upon total room surface area rather than room length and width. Total room surface area is calculated as:

$$
2(1)(w)+2(1)(H)+2(w)(H)
$$

where 1 is the length of the room, $w$ is the width of the room and $H$ is the room height. The room height used in the series discussed so far is $2.4 \mathrm{~m}$. 


\subsection{Effect of Room Height}

Figure 4, which is extracted from table 7, shows the increase in minimum flashover energy for ceiling heights $2.4 \mathrm{~m}$ ( $8 \mathrm{ft}$ ) and greater. An increase in ceiling height from $2.4 \mathrm{~m}$ ( $8 \mathrm{ft}$ ) to $12.2 \mathrm{~m}$ ( $40 \mathrm{ft}$ ), a 400 percent increase, resulted in only a 49 to $56 \%$ increase in minimum flashover energy. Figure 5 presents the effect of room height expressed as a percentage of the minimum flashover energy necessary to produce flashover in a room of the same size (length and width), the same door size with a $2.4 \mathrm{~m}$ ceiling. A linear regression provides a satisfactory fit to the equation

$$
\mathrm{P}_{\text {HEIGHT }}=100+5.3 \Delta \mathrm{H}
$$

where $\mathrm{P}_{\text {HEIGHT }}$ is the percentage increase in the minimum flashover energy for room heights greater than $2.4 \mathrm{~m}$ ( $8 \mathrm{ft}$ ) and $\Delta \mathrm{H}$ is the increase in ceiling height in meters. The correlation coefficient for the above equation is 0.91. For For example, for a $12.19 \mathrm{~m}$ ceiling height, $\Delta \mathrm{H}=9.75$ and $\mathrm{P}_{\text {HEIGHT }}=100+5.3 \mathrm{x}(9.75)=152$; the minimum energy required to produce flashover within a room with a ceiling height of $12.19 \mathrm{~m}$ is $152 \%$ of that required to produce flashover within a room with a $2.4 \mathrm{~m}$ ceiling.

Much of the spread in the data can be accounted for by the limited number of computer runs made to establish "minimum" flashover energies for a given geometry. From table 5, the difference in fire size for any two adjacent fire sizes is $0.24 \mathrm{MW}$. For the larger fires, this is less than $4 \%$. However, for the smaller fires, this is as much as $32 \%$. The difference between the curves in figure 4 is well below $32 \%$.

\subsection{Effect of Wa11 Lining}

Figures 6 and 7 illustrate the effect of changing the heat response (but not combustibility or ignition susceptibility) of the wall and 
ceiling lining material. For materials ranging from $12.7 \mathrm{~mm}$ thick expanded polystyrene insulation to $15 \mathrm{~cm}$ thick concrete, the minimum flashover energy increased less than $70 \%$ for a given room geometry. In figure 7, the minimum flashover energy for a given wall lining is expressed as a percentage of the minimum energy required to produce flashover in the equivalent room with a $12.7 \mathrm{~mm}$ thick gypsum wall lining. In this figure, $P_{\text {WALL }}$ is the percentage of the minimum flashover energy for gypsum wall lining $(\mathrm{k} \rho \mathrm{C}=0.18)$ that would be necessary to produce flashover in rooms lined with other materials, $k$ is the thermal conductivity in $\mathrm{W} / \mathrm{mK}, \rho$ is the density in $\mathrm{kg} / \mathrm{m}^{3}$ and $\mathrm{C}$ is the specific heat in $\mathrm{J} / \mathrm{kgK}$. For concrete $(\mathrm{k} \rho \mathrm{C}=2.88), \mathrm{P}_{\text {WALL }}=160$. Thus, the minimum energy required to produce flashover within a room with a ceiling height of $2.4 \mathrm{~m}$ ( $8 \mathrm{ft}$ ) with a concrete lining is predicted to be $160 \%$ of that required to produce flashover within the equivalent room with a gypsum lining. For all of these predictions it is assumed in the model that the wall lining does not ignite.

\subsection{Comparison with Test Data}

A number of ful1-scale fire tests have been performed in a wide variety of configurations. Table 9 summarizes some of the data [44] for tests where flashover was observed. In all cases, the predicted minimum flashover energy is lower than the observed maximum rate of heat release from the full-scale tests.

The predicted values average $70 \%$ of the observed with a range from $57 \%$ to $83 \%$. It is not surprising that the predicted minimum energy necessary to produce flashover is significantly less than the observed maximum rate of heat release. Several reasons why this should be expected are apparent: 
- The predicted minimum flashover energy is just that -- a minimum energy necessary to produce flashover for a given configuration. The rate of heat release for full-scale room fires was based upon maximum rates and thus may not be the minimum energy level.

- The fire algorithm simulates a fire which grows immediately upon ignition to a maximum size and remains constant at that level. Real fires would exhibit changes in fire size as the fire progressed. Thus, during most of the fire, the rate of heat release would be below the maximum level.

- The temperature limit selected as a definition of flashover was chosen purposely to be a conservative estimate. A higher temperature criterion would, of course, raise the predicted minimum flashover energy.

\subsection{Comparison with Other Predictions}

Three approaches were described in section 2 that have been applied to predict flashover. From Babrauskas [44] the relationship:

$$
\dot{q}=0.6 \mathrm{~A}(\mathrm{~h})^{1 / 2}
$$

from McCaffrey et al [45]:

$$
\dot{q}=0.61\left[\left(h_{k} A_{w} A(h)^{1 / 2}\right]^{1 / 2}\right.
$$

and from Thomas [17]:

$$
\dot{\mathrm{q}}=0.0078 \mathrm{~A}_{\mathrm{w}}+0.378 \mathrm{~A}(\mathrm{~h})^{1 / 2}
$$


The table below presents a comparison of these two predictions with those from figure 2. The value for $h_{k}=\sqrt{k} p C / t$ where $t$ is a "characteristic fire exposure time"; taken here to be $537 \mathrm{~s}$, which is the average of all "times to reach flashover" in table 5. The room size was chosen for this comparison rather arbitrarily simply as being in the middle of the range of room sizes studied. At small values of $A(h)^{1 / 2}$, both McCaffrey and Babrauskas present more conservative predictions. For values of $A(h)^{1 / 2}$ greater than $3-4 \mathrm{~m}^{5 / 2}$, the predictions of figure 2 are more conservative. Babrauskas assumes a ratio of $\mathrm{A}_{\mathrm{W}} / \mathrm{A}(\mathrm{h})^{1 / 2}$ of 50 . In the table below, this ratio ranges from 16 to 66 so the disagreement is not surprising. In addition, the criterion for flashover differs in the above formulations.

A Comparison of Techniques for the Prediction of Flashover

\begin{tabular}{|c|c|c|c|c|}
\hline $\begin{array}{l}A(h)^{1 / 2} \\
\left(\mathrm{~m}^{5 / 2}\right) \\
\end{array}$ & $\begin{array}{c}\text { from } \text { fig. } 2^{\mathrm{c}} \\
\dot{q} \\
(\mathrm{MW}) \\
\end{array}$ & $\begin{array}{c}\text { from ref. }[44]^{\mathrm{d}} \\
\dot{\mathrm{q}} \\
(\mathrm{MW})\end{array}$ & $\begin{array}{c}\text { from ref. }[45]^{a, b, c} \\
\dot{q} \\
(M W)\end{array}$ & $\begin{array}{c}\text { from ref. }[17]^{a, c} \\
\dot{q} \\
(M W)\end{array}$ \\
\hline 2 & 1.8 & 1.2 & 1.4 & 1.8 \\
\hline 4 & 2.2 & 2.4 & 1.9 & 2.5 \\
\hline 6 & 2.3 & 3.6 & 2.4 & 3.3 \\
\hline 8 & 2.4 & 4.8 & 2.7 & 4.0 \\
\hline
\end{tabular}

$$
\begin{array}{ll}
a-\text { room size } 131 \mathrm{~m}^{2} & \mathrm{~b}-\mathrm{h}_{\mathrm{k}}=0.019 \mathrm{~kW} / \mathrm{m}^{2} \mathrm{~K} \\
\mathrm{c}-\text { flashover at } \Delta \mathrm{T}=500^{\circ} \mathrm{C} & \mathrm{d}-\mathrm{fl} \text { - flashover at } \Delta \mathrm{T}=575^{\circ} \mathrm{C}
\end{array}
$$

\section{USING THE MODEL PREDICTIONS TO DETERMINE MINIMUM FLASHOVER ENERGY}

The use of figures 3,5 and 7 to predict a minimum energy necessary for flashover is straightforward. For any room with wall linings similar to the types studied above, a calculation is made of the total surface area of an equivalently sized room with a $2.4 \mathrm{~m}$ ( $8 \mathrm{ft}$ ) ceiling by

$$
A_{W}=2(2.4 \times 1)+2(2.4 \times w)+2(1 \times w)
$$


Figure 2 is used to determine the minimum flashover energy for the room area $A_{W}$ with the appropriate ventilation factor $-A(h)^{1 / 2}$. If the ceiling height is greater than $2.4 \mathrm{~m}$ ( $8 \mathrm{ft}$ ), this minimum flashover energy is modified by a percentage

$$
\mathrm{P}_{\text {HEIGHT }}=100+5.3 \Delta \mathrm{H}
$$

where $\Delta \mathrm{H}$ is the increase in height over $2.4 \mathrm{~m}$ in meters. If the wall material is other than the $13 \mathrm{~mm}$ (1/2 in) gypsum wallboard, the minimum flashover energy is further modified by a percentage, $P_{\text {WALL }}$ from figure 7 based upon $\mathrm{k} \rho \mathrm{C}$ where $\mathrm{k}$ is the thermal conductivity in $\mathrm{W} / \mathrm{mK}, \rho$ is the density in $\mathrm{kg} / \mathrm{m}^{3}$ and $\mathrm{C}$ is the specific heat in $\mathrm{J} / \mathrm{kgK}$. By definition, $P_{\text {WALL }}$ for $1 / 2$ " gypsum wallboard is 100 . From the predictions made, the limitations of these calculations are:

$$
\begin{aligned}
& A_{w}--48 \text { to } 323\left(\mathrm{~m}^{2}\right) \\
& \Delta \mathrm{H}--0 \text { to } 9.75(\mathrm{~m})
\end{aligned}
$$

A material similar to the ones studied in both thickness and properties.

or

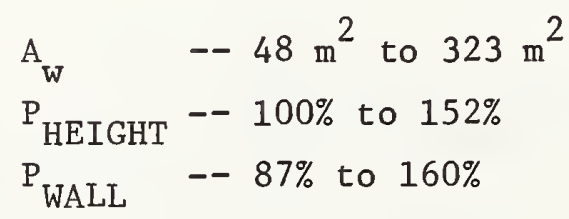

As an example, consider a room $5 \mathrm{~m}$ long $\times 7 \mathrm{~m}$ wide $\times 4 \mathrm{~m}$ high with a doorway $2 \mathrm{~m}$ wide $\mathrm{x} 2 \mathrm{~m}$ high that is lined with $4 \mathrm{in}$. thick brick $\left(\mathrm{k} \rho \mathrm{C}=1.66 \times 10^{6}\right)$. From above, 


$$
\begin{aligned}
A_{W} & =2(2.4 \times 5)+2(2.4 \times 7)+2(5 \times 7) \\
= & 128 \mathrm{~m}^{2} \\
A(h)^{1 / 2} & =2\left(2 \times(2)^{1 / 2}\right. \\
& =5.7
\end{aligned}
$$

From figure 2, the minimum flashover energy is predicted to be $2.25 \mathrm{MW}$. Since the ceiling height is more than $2.4 \mathrm{~m}$ ( $8 \mathrm{ft}$ ), this is modified by

$$
\begin{aligned}
\mathrm{P}_{\text {HEIGHT }} & =100+5.3(1.6) \\
& =108 \%
\end{aligned}
$$

and modified for the brick wall surface by

$$
\mathrm{P}_{\text {WALL }}(\mathrm{k} \rho \mathrm{C}=1.66)=142 \%
$$

Therefore the minimum flashover energy would be 2.25 MW $(1.08)(1.42)=$ 3.45 MW.

\section{CONCLUSIONS, RECOMMENDATIONS AND LIMITATIONS}

A technique has been presented to estimate the minimum energy necessary to produce flashover in a variety of room configurations. Using a series of curves developed from a computer fire growth model, the minimum flashover energy is estimated. The effects of raising the ceiling height and of variation in the room lining material were investigated. The limitations on the parameters studied were: 


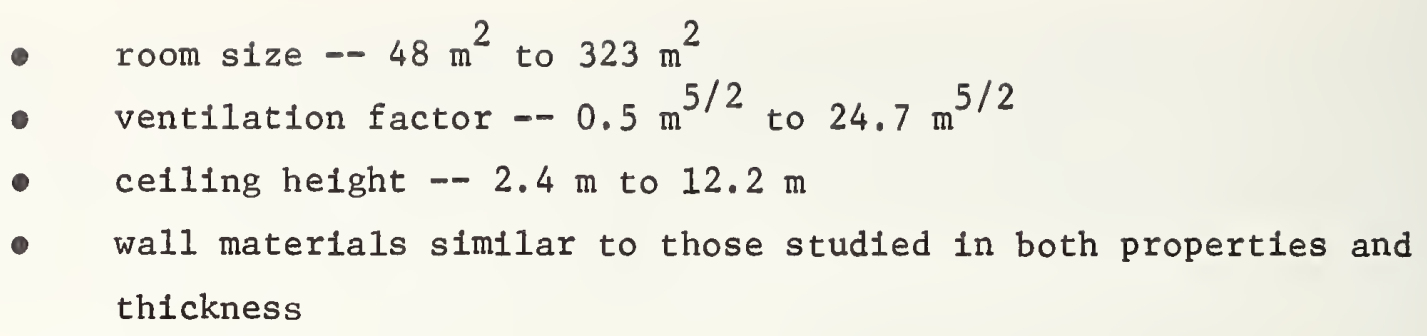

\subsection{Limitations of this Study}

This study presents an initial look at the potential for the use of fire growth models to predict the occurrence of flashover. A number of limitations of the study are apparent:

- the study centered on one fire model - a steady fire. Although a "worst-case" simulation, it does not accurately model most fires. A growing fire as proposed by Cooper [42] or a fire which grows to a peak then dies down would represent a more typical fire.

- An investigation of additional room sizes, celling heights and wall lining materials would extend the study and increase the usefulness of the predictions.

- The definition of flashover used for this study $\left(\Delta \mathrm{T}=500^{\circ} \mathrm{C}\right)$ is certainly not the only one that could be chosen. A temperature limit of $600-650^{\circ} \mathrm{C}$ should be investigated. A definition in terms of the heat flux at floor level would perhaps give more information on the ignition of other items within the room.

- In all the predictions presented here, the wall lining material was assumed not to ignite. Certainly many typical lining materials do ignite. As the sophistication of the models increase, this effect should be studied. 
- The model predictions presented here are more conservative than all other predictions at large ventilation factors. The reasons for this should be investigated and should provide insight into the effects of large openings during fires.

\subsection{The Link With Room Furnishings}

One important area of information which limits the usefulness of this study is the relationship of the burning behavior of actual room furnishing items to the minimum flashover energy. Two major stumbling blocks are foreseen -- 1) a catalog of the rates of heat release of typical furnishing items and 2) how should this rate of heat release be interpreted for the fire growth model.

In the first area, some information is available. Babrauskas $[6,13]$ has provided mass burning rates and heats of combustion for mattresses and upholstered chairs. Lawson [49] has begun actual measurement of the rate of heat release of furnishings. The following table provides an indication of the range of burning behavior of furnishings.

\begin{tabular}{|c|c|c|c|c|}
\hline & RHR & (MW) & $\begin{array}{c}\text { Time Above } \\
50 \% \text { of Maximum }\end{array}$ & Reference \\
\hline Mattresses & 0.08 & to 1.7 & $150-800^{c}$ & Babrauskas [6] \\
\hline Chairs & 0.2 & to 3.9 & n.a. & Babrauskas [13] \\
\hline Chairs & 1 & to 3 & n.a. & Lawson [49] \\
\hline Metal Wardrobe $e^{a}$ & & 0.2 & 60 & Laws on [49] \\
\hline Wooden Wardrobe $a, b$ & & 6.4 & 55 & Lawson [49] \\
\hline
\end{tabular}


Considerably more information is necessary on furnishings to be able to determine how these rate of heat release data compare to the minimum flashover energy. One possible method would be to define (from the furnishing RHR curves) a maximum rate of heat release and a duration of the fire for various furnishing categories. These could be used to define an appropriate fire model for predictions such as those made in this study. The details of how this would be accomplished are, of course, still to be determined.

\section{ACKNOWLEDGEMENTS}

This study was sponsored by the U.S. Department of Health and Human Services. This support is gratefully acknowledged. Thanks are also due to Mr. H. Nelson and Dr. L.Y. Cooper for their guidance in the initial design of the study and for their insight in seeing the need and potential for the use of computer modeling.

\section{REFERENCES}

[1] Harmathy, T.Z., A New Look at Compartment Fires, Part I, Fire Technology, Vol. 8, No. 3, 196-217 (August 1972).

[2] Harmathy, T.Z., A New Look at Compartment Fires, Part II, Fire Technology, Vo1. 8, No. 4, 326-351 (November 1972).

[3] Heselden, A.J.M., Results of an International Co-operative Programme on Fully-Developed Fires in Single Compartments. Fire-Resistance Requirements for Buildings--A New Approach. Symposium No. 5, 2-13, Proceedings of the Joint Fire Research Organization, London, September 28, 1971 (1973).

[4] Thomas, P.H., and Heselden, A.J.M., Fully-Developed Fires in Single Compartments. A Co-operative Research Programme of the Conseil International du Bâtiment, Fire Research Note No. 923, Fire Research Station, Borehamwood (1972).

[5] Hagglund, B., Janson, R., and Onnermark, B., Fire Development in Residential Rooms After Ignition from Nuclear Explosions, FOA C20016-DG (A3), Forsvarets Forskningsanstalt, Stockholm (1974). 
[6] Babrauskas, V., Combustion of Mattresses Exposed to Flaming Ignition Sources, Part I. Full-Scale Tests and Hazard Analysis, Nat. Bur. Stand. (U.S.), NBSIR 77-1290 (1977).

[7] Fang, J.B., Fire Buildup in a Room and the Role of Interior Finish Materials, Nat. Bur. Stand. (U.S.), Tech. Note 879 (1975).

[8] Budnick, E.K., Mobile Home Living Room Fire Studies: The Role of Interior Finish, Nat. Bur. Stand. (U.S.), NBSIR 78-1530 (1978).

[9] Budnick, E.K., Klein, D.P., and O'Laughlin, R.J., Mobile Home Bedroom Fire Studies: The Role of Interior Finish, Nat. Bur. Stand. (U.S.), NBSIR 78-1531 (1978).

[10] Klein, D.P., Characteristics of Incidental Fires in the Living Room of a Mobile Home, Nat. Bur. Stand. (U.S.), NBSIR 78-1522 (1978).

[11] Budnick, E.K., and Klein, D.P., Mobile Home Fire Studies: Summary and Recommendations, Nat. Bur. Stand. (U.S.), NBSIR 79-1720 (1979).

[12] Lee, B.T. and Breese, J.N., Submarine Compartment Fire Study Fire Performance Evaluation of Hull Insulation, Nat. Bur. Stand. (U.S.), NBSIR 78-1584 (1979).

[13] Babrauskas, V., Fu11-Scale Burning Behavior of Upholstered Chairs, Nat. Bur. Stand. (U.S.), Tech. Note 1103 (1979).

[14] Fang, J.B. and Breese, J.N., Fire Development in Residential Basement Rooms, Nat. Bur. Stand. (U.S.), NBSIR 80-2120 (1980).

[15] Quintiere, J.G. and McCaffrey, B.J., The Burning of Wood and Plastic Cribs in an Enclosure: Volume I, Nat. Bur. Stand. (U.S.), NBSIR 80-2054 (1980).

[16] McCaffrey, B.J. and Rocket, J.A., Nat. Bur. Stand. (U.S.)., J. Res., Vo1. 82, No. 2, 107-117 (1977).

[17] Thomas, P.H., Testing Products and Materials for Their Contribution to Flashover in Rooms, Fire and Materials, Vol. 5, No. 3, 103-111 (September 1981).

[18] Parker, W.J. and Lee, B.T., Fire Build-Up in Reduced Size Enclosures. In: Fire Safety Research, proceedings of a symposium held at the National Bureau of Standards, Gaithersburg, MD on August 22, 1973. M.J. Butler and J.A. Slater, eds. Nat. Bur. Stand. (U.S.), NBS SP411, pp 139-53 (1974).

[19] Smith, W.K., Naval Weapons Center, China Lake (unpublished reports). 
[20] Friedman, R., Status of Mathematical Modeling of Fires, Factory Mutual Research Corporation, FMRC RC81-BT-5 (1981).

[21] Levine, R.S., Mathematical Modeling of Fires, Nat. Bur. Stand. (U.S.), NBSIR 80-2107 (1980).

[22] Thomas, P.H., Theoretical Considerations of the Growth to Flashover of Compartment Fires, Fire Research Note No. 663, Fire Research Station, Borehamwood (1967).

[23] Torrance, K.E. and Rockett, J.A., Experiments on Natural Convection in Enclosures with Localized Heating from Below, J. Fluid Mech., Vol. 36, No. 1, 33-54 (1969).

[24] Tanaka, T., A Mathematical Model of a Compartment Fire, Building Research Institute (Japan), BRI Research Paper 非0 (1977).

[25] Hasemi, Y., Numerical Simulation of Fire Phenomena and Its Application, Building Research Institute (Japan), BRI Research Paper 非6 (1976).

[26] Mitler, H.E., The Physical Basis for the Harvard Computer Fire Code, Home Fire Project Technical Report 非39, Harvard University, Division of Engineering and Applied Science (1978).

[27] Mitler, H.E., User's Guide for the Harvard Computer Fire Code, Home Fire Project Technical Report 非37, Harvard University, Division of Engineering and Applied Science (1979).

[28] Emmons, H.W., Computer Fire Code (II), Home Fire Project Technical Report 非20, Harvard University, Division of Engineering and Applied Science (1977).

[29] Emmons, H.W., The Prediction of Fires in Buildings, Seventeenth International Symposium on Combustion, 1101-1113, The Combustion Institute, Pittsburgh, PA (1979).

[30] Emmons, H.W., Scientific Progress on Fires, Ann. Rev. Fluid Mech. 1980, Vol. 12, 223-236 (1980).

[31] Emmons, H.W., The Calculation of Fire in a Large Building, ASME 20th Nat1. Heat Transfer Conf., Milwaukee, WI (1981).

[32] Pape, R., Waterman, T.E., and Eichler, T.V., Development of a Fire in a Room From Ignition to Full Room Involvement -- RFIRES, contract to Nat. Bur. Stand. (U.S.), NBS GCR 81-301 (1981).

[33] Pape, R., Preflashover Room Fire Model: Parametric Sensitivity Analysis and Development of a Submodel for Burning Furniture Items, contract to Nat. Bur. Stand. (U.S.), NBS GCR 81-300 (1981). 
[34] Pape, R., Mavec, J., Kalkbrenner, D., Waterman, T., Program Documentation and User's Guide - Semistochastic Approach to Predicting the Development of a Fire in a Room from Ignition to Flashover RFIRES, contract to Nat. Bur. Stand. (U.S.), NBSGCR 77-111 (June 1976).

[35] Pape, R. and Waterman, T., Program Documentation and User's Guide (Addendum) - Semistochastic Approach to Predicting the Development of a Fire in a Room from Ignition to Flashover - RFIRES, contract to Nat. Bur. Stand. (U.S.), NBSGCR 77-112 (1976).

[36] Waterman, T. and Pape, R., A Study of the Development of Room Fires, contract to Nat. Bur. Stand. (U.S.), NBSGCR 77-110 (September 1976).

[37] Pape, R. and Waterman, T., Modifications to the RFIRES Preflashover Room Fire Computer Model, contract to Nat. Bur. Stand. (U.S.), NBSGCR 77-113 (March 1977).

[38] Pape, R., Computer Simulation of Ful1-Scale Room Fire Experiments, Illinois Institute of Technology Research Institute, Final Report J6414 (March 1978).

[39] Pape, R. and Waterman, T., "Understanding and Modeling Preflashover Compartment Fires," Design of Buildings for Fire Safety, ASTM STP685, E.E. Smith and T.Z. Harmathy, Eds., American Society for Testing and Materials, pp 106-138 (1979).

[40] Quintiere, J.G., Growth of Fire in Building Compartments, ASTM Special Publication 614, A.F. Robertson, ed., pp 131-167 (1977).

[41] Quintiere, J.G., Steckler, K., and McCaffrey, B.J., A Model to Predict the Conditions in a Room Subject to Crib Fires, Proceedings of the Fire Specialists Meeting of the Combustion Institute, Bordeaux, France (July 20-24, 1981).

[42] Cooper, L.Y., Estimating Safe Available Egress Time from Fires, Nat. Bur. Stand. (U.S.), NBSIR 80-2172 (1981).

[43] Friedman, R., Quantification of Threat from a Rapidly Growing Fire in Terms of Relative Material Properties, Fire and Materials, Vol. 2, No. 1, 27-33 (1978).

[44] Babrauskas, V., Estimating Room Flashover Potential, Fire Technology, Vo1. 16, No. 2, 94-103 (1980).

[45] McCaffrey, B.J., Quintiere, J.G. and Harkleroad, M.F., Estimating Room Temperatures and the Likelihood of Flashover Using Fire Data Correlations, Fire Technology, Vol. 17, No. 2, 98-119 (1981).

[46] Bohm, B., "Fully Developed Polyethylene and Wood Compartment Fires with Application to Structural Design," Ph.D. dissertation, Technical University of Denmark, Lyngby (1977). 
[47] Alpert, R.L., et. al., "Influence of Enclosures on Fire Growth, vol. 1, Tests 1, 2, 6 and 7, Serial OAOR2.BU-1, 2, 6, 7, Factory Mutual Research Corporation, Norwood, Mass. (1977).

[48] Heselden, A.J.M., Smith, P.G., and Theobald, C.R., "Fires in a Large Compartment Containing Structural Steelwork, Detailed Measurements of Fire Behaviour," F.R. Note 646, Fire Research Station, Borehamwood (1966).

[49] Lawson, R., Center for Fire Research, personal communication. 


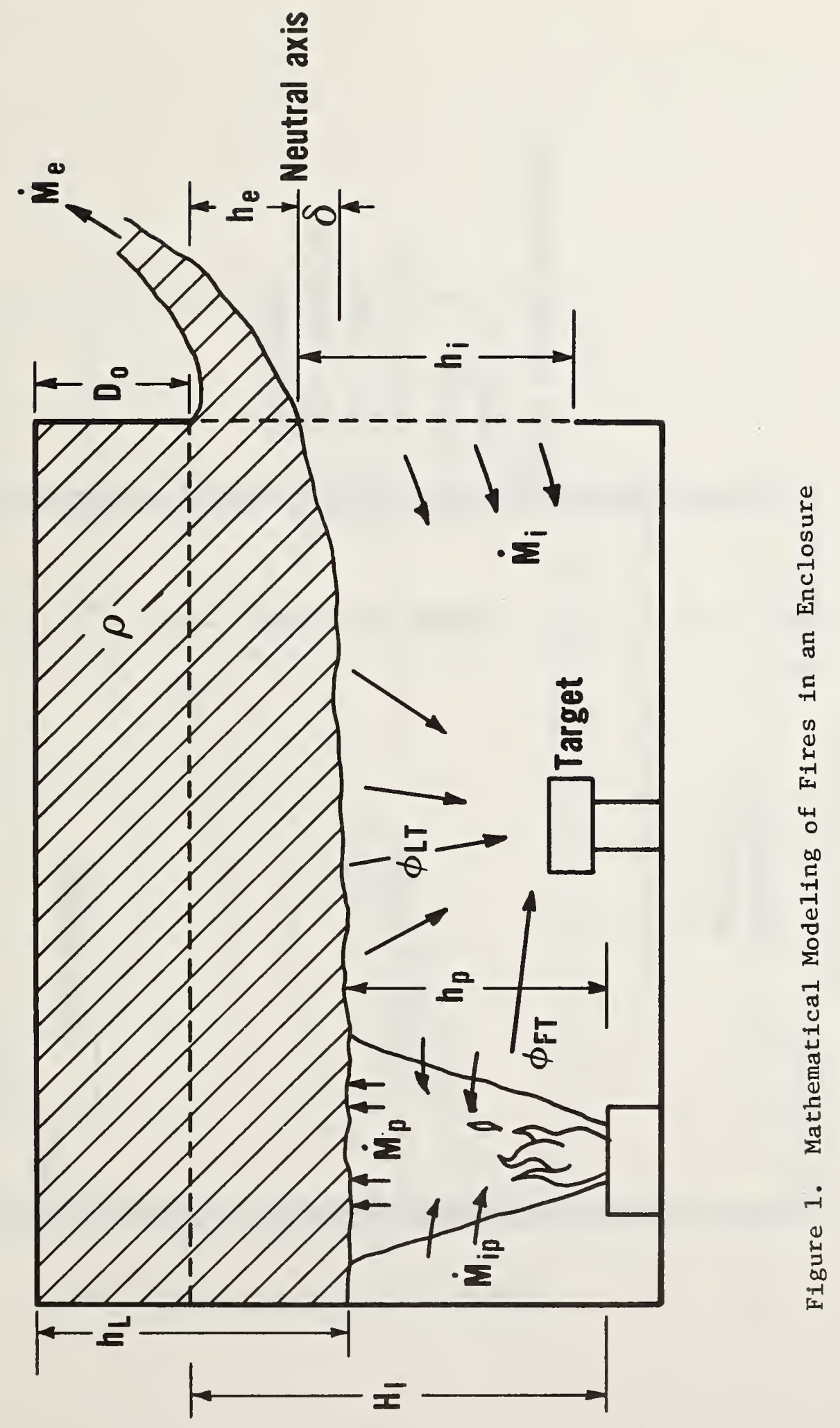




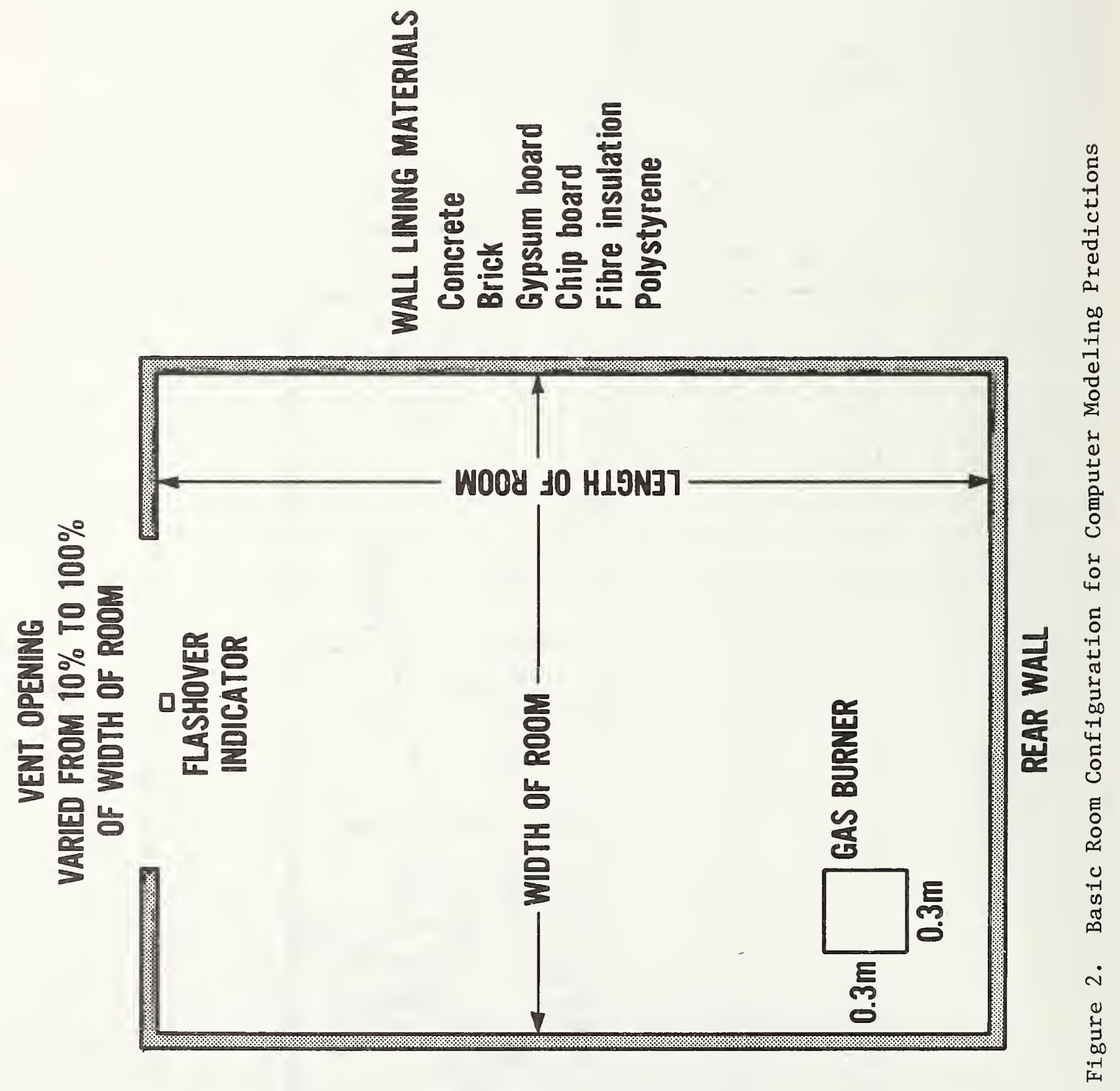




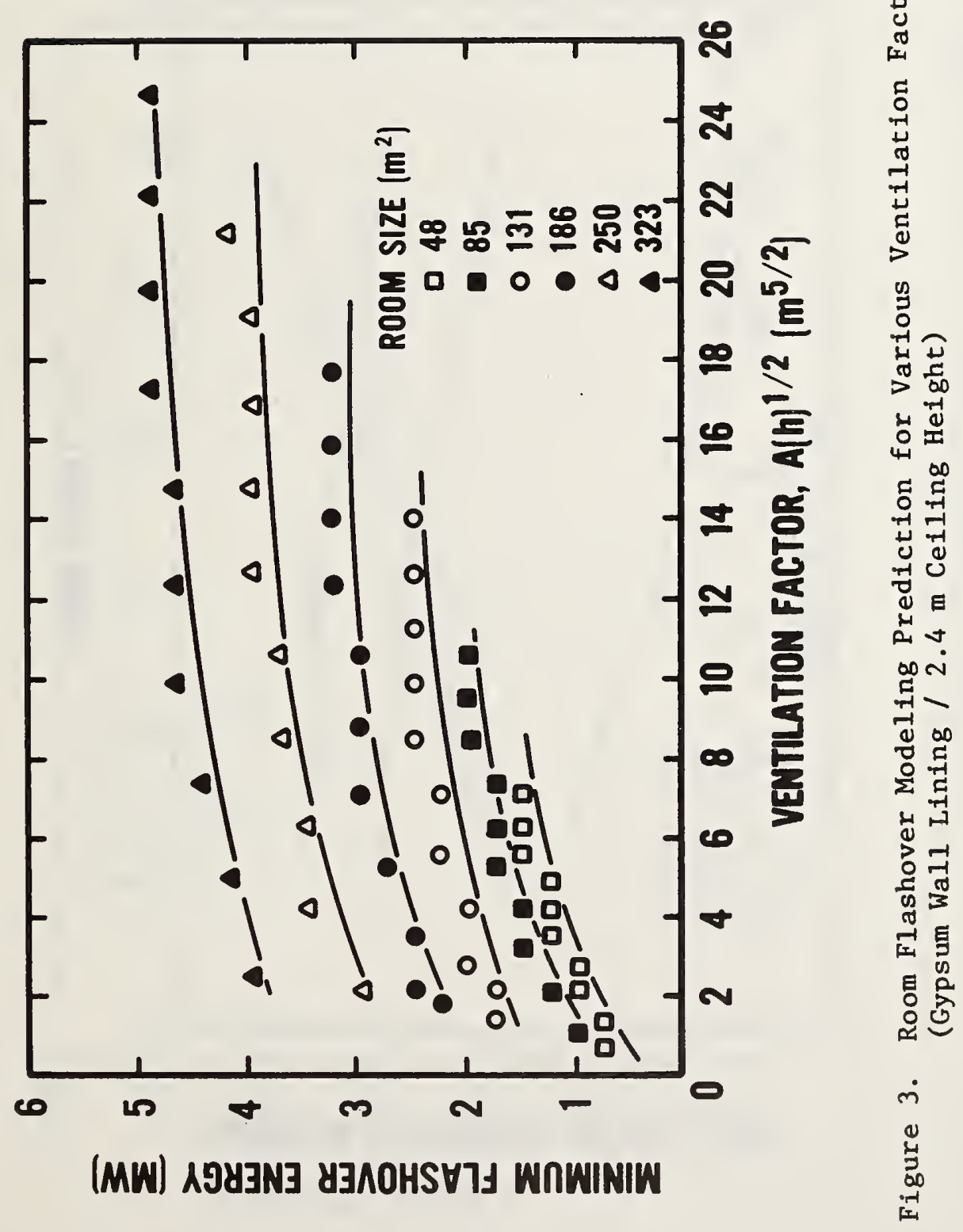




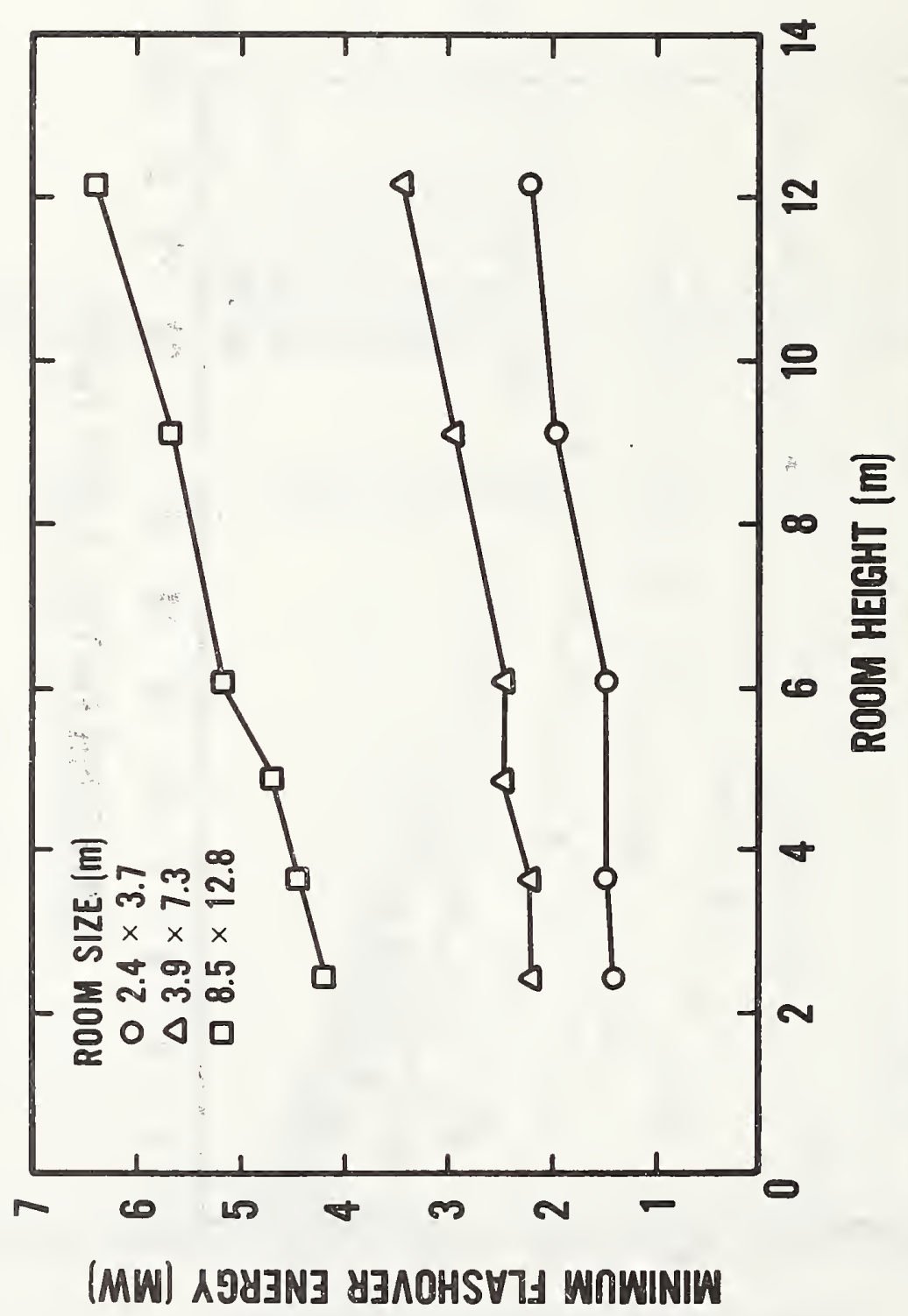

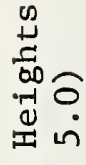

हี "I

भज

ํํㅇำ

त्र

$>$ मै

मे

용

告

总

至

空

3

学貝

토

엉

j

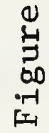




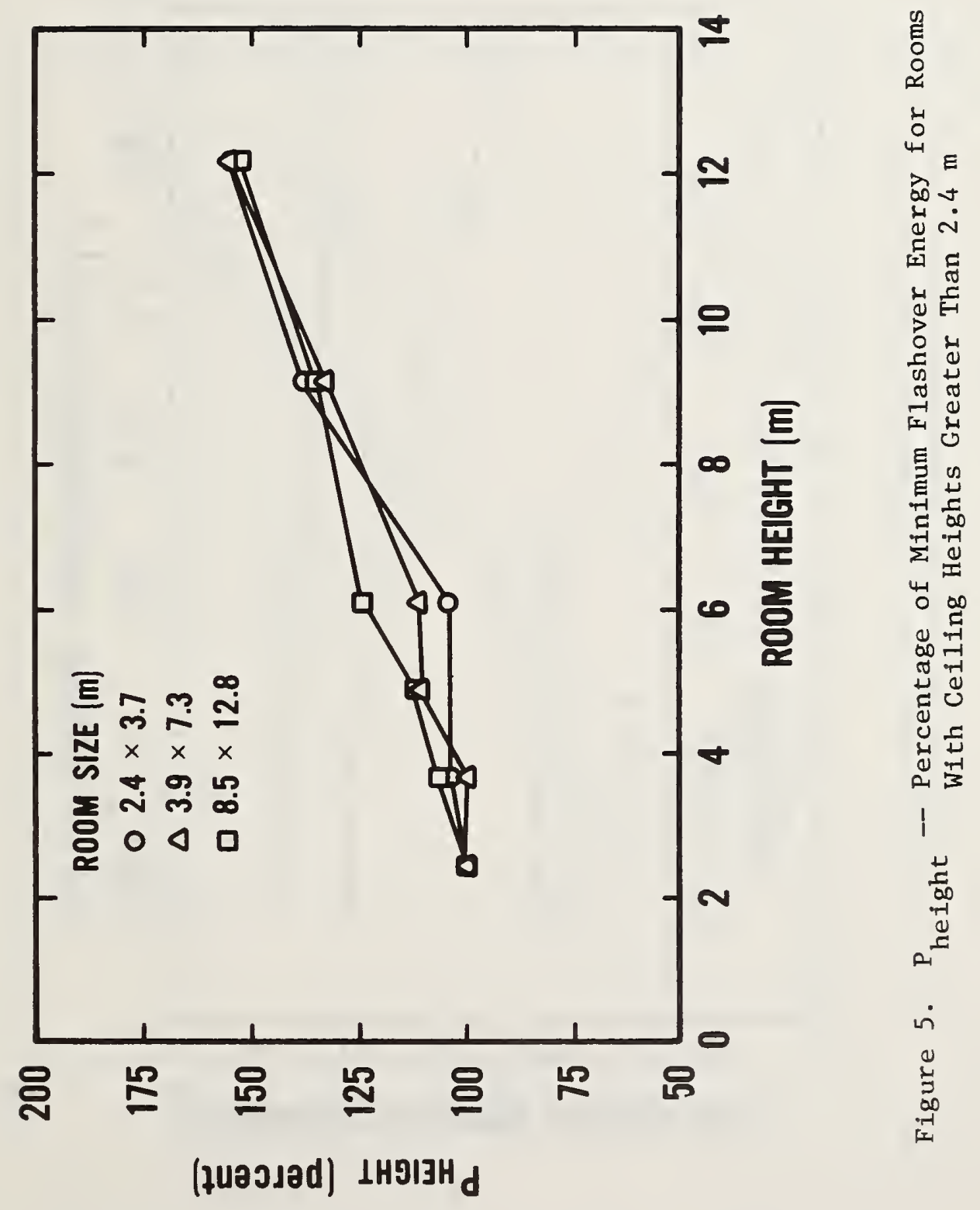




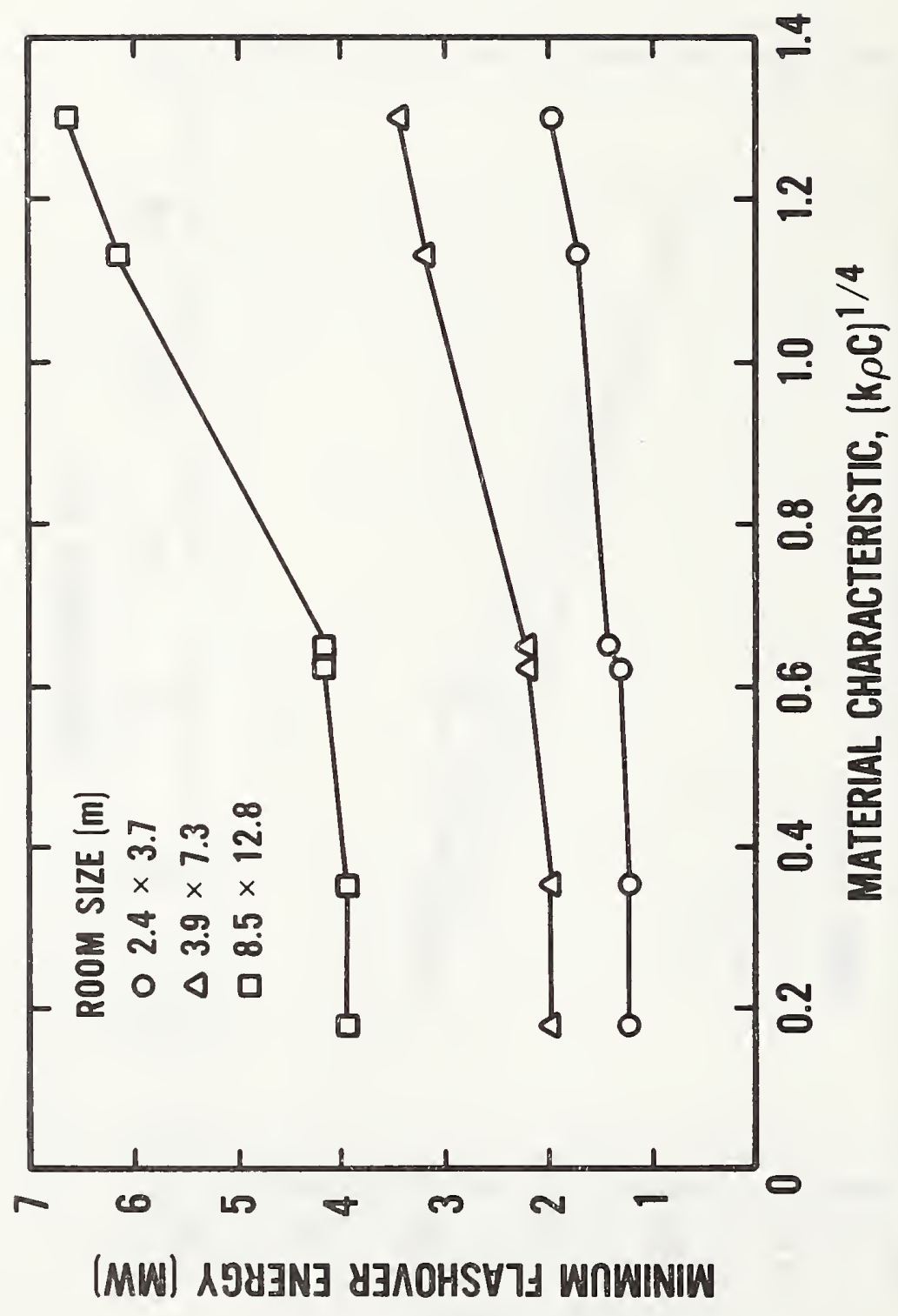

告

ํㅜㄹ

म॥

HN

अ

此

우

幽

4

$0_{4-1}^{0}$ F.

동 동-1

म्न

0 न

"马

近

Q $>$

-

럼

-1

일

4.

$>$.

음 걱

告

달

ํㅜㅇ

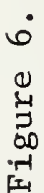




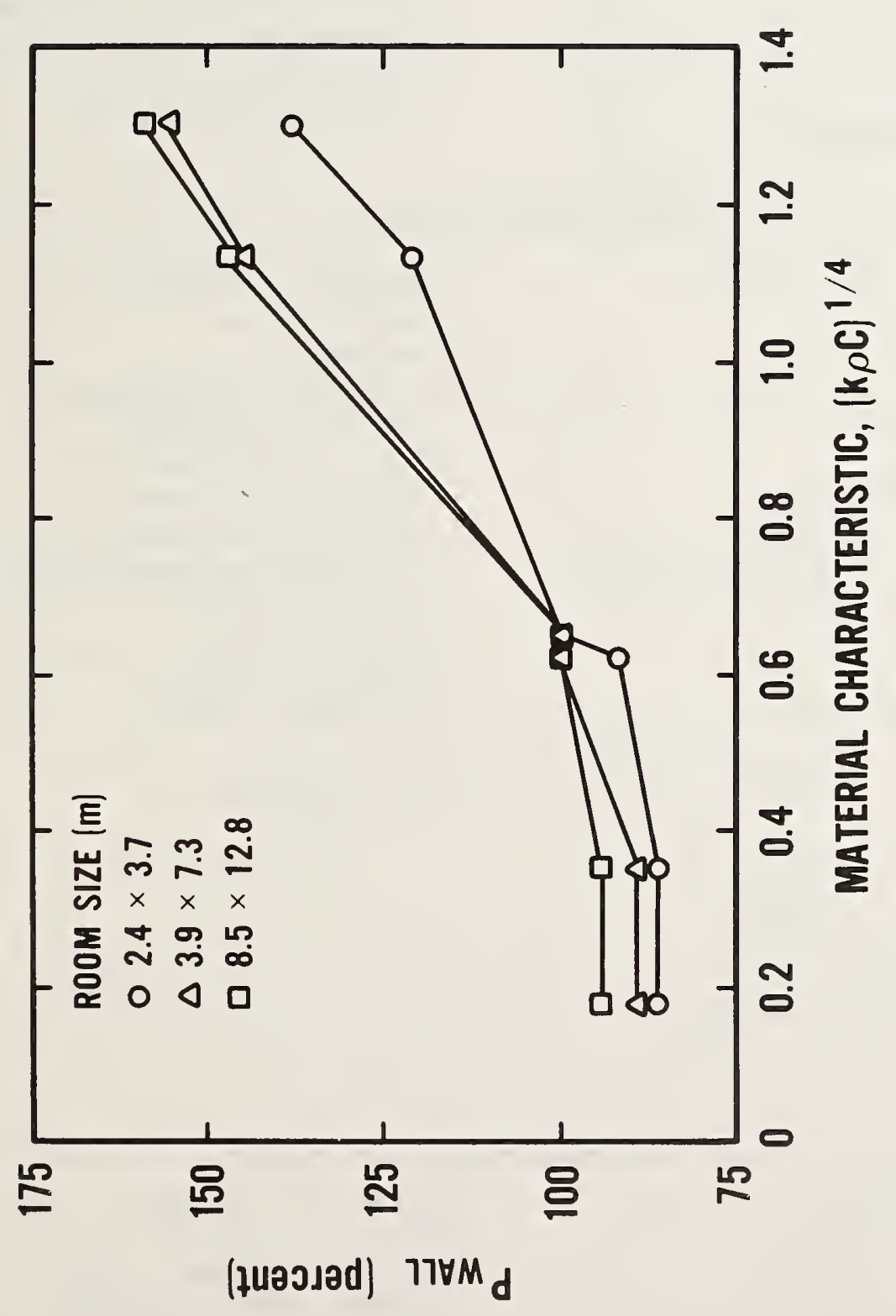

先

덩

ํㅜㄴ

命

นู

$>\infty$

漹

告 合

E

总骢

正

4- 耑

0

a o

㐘

过

บ

a d

I

점

i

$\underset{\substack{1 \\ \infty}}{\infty}$ 
Table 1. Parameters that Can Be Varied in the Harvard Model

\section{Room Characteristics}

Length of room

Width of room

Height of room

Number of objects in room

Ambient air temperature

Vent width

Vent height

Vent transom depth

Wall thickness

Wall thermal conductivity
Wall specific heat

Wall density

Specific heat of air

Absorption coefficient of flame

Outside ambient temperature

Maximum heat transfer coefficient

Minimum heat transfer coefficient

Plume entrainment coefficient

Vent flow coefficient

\section{Object Characteristics}

Location of object (X, Y and Z)

Angle with horizontal

Angle with XZ-plane

Thickness

Initial burning radius

Object radius

Maximum burning radius

Length and width of object

Burning algorithm

Air/fuel ratio

Stochiometric A/F ratio

Gas flow rate

Fire spread parameter
Thermal conductivity

Specific heat

Emissivity

Combustion efficiency

Heat of combustion

Heat of vaporization

Initial fuel mass

Ignition temperature

Pyrolization temperature

$\mathrm{CO}_{2} /$ fuel ratio

coffuel ratio

Smoke/fuel ratio

Water/fuel ratio

\section{Default Conditions (all units S.I.)}

Room number 1:

Length along $\mathrm{X}=2.4384$

Length along $y+3.6576$

Height $=2.4384$

Ambient temperature $=300.0$

Object number $1($ ID $=1)$ :

$\mathrm{X}-$ coord $=.8400 ; \mathrm{Y}$-coord $=2.8180 ;$ height $=.6100$

Angle with horizontal $=.00$

Thickness $=.1000$

Initial mass $=6.8520$

Maximum radius $=.9677$

Specific heat $=1900$.

Emissivity $=.98$

Heat of combustion $=.287+008$

Pyrolization temp $=600.0$

Air/fuel mass ratio $=14.45$

$\mathrm{FCO}_{2}\left(\mathrm{CO}_{2}\right.$ mass $/ \mathrm{fuel}$ mass $)=1.504$

FS (smoke mass/fuel mass) $=.241$

$A($ fire spread parameter $)=.0109$

Angle with $\mathrm{XZ}-\mathrm{plane}=.00$

Density $=48.00$

Initial radius $=.0370$

Object radius $=.8598$

Thermal conductivity $=.0540$

Chi (fraction of heat released) $=.65$

Heat of vaporization $=.205+007$

Ignition temp $=727.0$

Stochiometric mass ratio $=9.85$

$\mathrm{FCO}(\mathrm{CO} \mathrm{mass} / \mathrm{fuel} \mathrm{mass})=.013$

$\mathrm{FH}_{2} \mathrm{O}\left(\mathrm{H}_{2} \mathrm{O}\right.$ mass/fuel mass $)=.714$ 
Table 1. Continued

Object number 2 (ID $=2)$ :

$\mathrm{X}-$ coord $=2.0800 ; \mathrm{Y}-\operatorname{coord}=2.8180 ;$ height $=.8640$

Angle with horizontal $=.00$

Angle with $\mathrm{XZ}-\mathrm{plane}=.00$

Thickness $=.1000$

Density $=48.00$

Initial mass $=1.0963$

Initial radius $=.0370$

Maximum radius $=.4657$

Object radius $=3.439$

Specific heat $=1900$.

Emissivity $=.98$

Heat of combustion $=.287+008$

Thermal conductivity $=.0540$

Chi (fraction of heat released) $=.65$

Pyrolization temp $=600.0$

Heat of vaporization $=.205+007$

Air/fuel mass ration $=14.45$

Ignition temp $=740.0$

$\mathrm{FCO}_{2}\left(\mathrm{CO}_{2}\right.$ mass/fuel mass $)=1.504$

Stochiometric mass ratio $=9.85$

$\mathrm{FS}$ (smoke mass/fuel mass) $=.241$

$\mathrm{FCO}$ (CO mass/fuel mass) $=.013$

A (fire spread parameter) $=.0109$

$\mathrm{FH}_{2} \mathrm{O}\left(\mathrm{H}_{2} \mathrm{O}\right.$ mass/fuel mass $)=.714$

Vent number 1:

Width $=.7620 ;$ height $=2.0320 ;$ transom depth $=.4064$

Wa11 number 1:

Thickness $=.0254$

Density $=800.00$

Specific heat $=1062$

Thermal conductivity $=.1340$

Physical constants:

Specific heat of air $=1004$

Absorption coeff. of flame $=1.55$

For air:

Heat transfer coeff. $=10.00$

Plume entrainment coeff. $=.10$

For layer gases:

Max. heat transfer coeff. $=50.00$

Min. heat transfer coeff. $=5.00$

For vents:

Flow coefficient $=.68$ 
Table 2. Room and Vent Sizes Investigated

\section{Ventilation Factor Series}

Room Size

(m)

$2.4 \times 3.6$

$3.6 \times 5.5$

$4.9 \times 7.3$

$6.1 \times 9.1$

$7.3 \times 11$

$8.5 \times 12.8$
Room Area

$\left(m^{2}\right)$

48

85

131

186

250

323
Ventilation Factor $A(h)^{1 / 2} \quad\left(m^{5 / 2}\right)$

$0.7-7.1$

$1.1-10.6$

$1.4-14.1$

$1.8-17.7$

$2.1-21.2$

$2.2-24.7$

\section{Room Height Series}

Room surface areas: $48 \mathrm{~m}^{2}, 131 \mathrm{~m}^{2}, 323 \mathrm{~m}^{2}$

Ceiling height: $2.4 \mathrm{~m}-12.2 \mathrm{~m}$

\section{Wa11 Lining Series}

Room surface areas: $48 \mathrm{~m}^{2}, 131 \mathrm{~m}^{2}, 323 \mathrm{~m}^{2}$

Six materials, each with a typical characteristic thickness. 
Table 3. Thermal Properties of Room Lining Materials ${ }^{\text {a }}$

$\begin{array}{cccc}\text { Density } & \begin{array}{c}\text { Specific } \\ \text { Heat }\end{array} & \begin{array}{c}\text { Thermal } \\ \text { Conductivity }\end{array} \\ \rho & \mathrm{c} & \mathrm{k} \times 10^{3} & \mathrm{k \rho c} \\ \frac{\mathrm{kg}}{\mathrm{m}^{3}} & \frac{\mathrm{kJ}}{\mathrm{kg} \cdot \mathrm{K}} & \frac{\mathrm{kW}}{\mathrm{m} \cdot \mathrm{K}} & \end{array}$

$\begin{array}{lr}\text { Aluminum (pure) } & 2710 \\ \text { Concrete } & 2400 \\ \begin{array}{l}\text { Asbestos-cement. } \\ \text { board (heavy) }\end{array} & 2100 \\ \text { Brick } & \\ \text { Brick/concrete block } & 2600 \\ \text { Gypsum board } & 1900 \\ \text { Plasterboard } & 960 \\ \text { Plywood } & 950 \\ \text { Chipboard } & 540 \\ \text { Aerated concrete } & 800 \\ \text { Cement-asbestos board } & 500 \\ \text { Calcium silicate } & 658 \\ \text { board } & \\ \text { Fibre insulation board } & 240 \\ \text { Alumina silicate block } & 260 \\ \text { Glass fibre insulation } & \\ \text { Expanded polystyrene } & \\ \text { From reference [39]. } & \\ & \\ & \end{array}$

$.895 \quad 206 \quad 500$

$\begin{array}{lll}.75 & 1.6 & 2.88\end{array}$

$\begin{array}{lll}1.0 & 1.1 & 2.31\end{array}$

$\begin{array}{lll}0.8 & 0.8 & 1.66\end{array}$

$\begin{array}{lll}.84 & .73 & 1.17\end{array}$

$\begin{array}{llll}960 & 1.1 & .17 & 0.180\end{array}$

$\begin{array}{llll}950 & .84 & .16 & 0.127\end{array}$

$\begin{array}{llll}540 & 2.5 & .12 & 0.162\end{array}$

$\begin{array}{llll}800 & 1.25 & .15 & 0.150\end{array}$

$\begin{array}{llll}500 & .96 & .26 & 0.1248\end{array}$

$\begin{array}{llll}658 & 1.06 & .14 & 0.0976\end{array}$

$\begin{array}{llll}700 & 1.12 & .11-.14 & 0.0862\end{array}$

$\begin{array}{llll}240 & 1.25 & .053 & 0.0159\end{array}$

$\begin{array}{lll}260<1> & .14 & 0.0464\end{array}$

$\begin{array}{lll}60 & .037 & 1.78 \times 10^{-3}\end{array}$

$20 \quad 1.5 \quad .034 \quad 1.02 \times 10^{-3}$ 
Table 4. Key to Values Appearing in Tables 5, 6, 7 and 8

Unless otherwise specified:

Room height $=2.44 \mathrm{~m}$

Vent (door) size: width $=1.73 \mathrm{~m}$

$$
\text { height }=2.03 \mathrm{~m}
$$

$\mathrm{A}(\mathrm{h})^{1 / 2}=5.00$

Flashover is defined as having occurred at an energy level if the temperature reaches $800 \mathrm{~K}(\Delta \mathrm{T}=500$ degrees $)$ within 900 seconds.

The numbers below the steady state energy are the times in seconds required to reach flashover for that energy output level.

A boxed number is the time in seconds required to reach flashover with the minimum energy output level (of those energy levels investigated).

A number in parentheses is the temperature $(K)$ at $t$ ime $t=900 \mathrm{~s}$ when flashover has not occurred at that energy level.

+ room width and length were exchanged to accommodate door width.

* steady state fire energy output level not reached.

非 fire is oxygen starved at some time.

s standard width door $(0.76 \mathrm{~m})$ 
Table 5A. Effect of Vent Size on Time and Energy Needed to Achieve Flashover Room size: length $=2.44 \mathrm{~m}$, width $=3.66 \mathrm{~m}$, height $=2.44 \mathrm{~m}$

Vent Characteristics

Steady State Energy Output (MW)

Vent (Door)

Width

(\% of room length)

10

20

30

$31^{\mathrm{s}}$

40

50

60

70

80

90

100
Vent Wid th

(m)

0.24

0.49

0.73

2.1

0.76

2.2

0.98

2.8

1.22

3.5

1.46

4.2

1.71

4.9

1.95

5.6

2.19

6.3

2.44

7.1
0.49

$0.74 \quad 0.98$

$1.23 \quad 1.48$

1.72

(755)

\begin{tabular}{|c|c|c|}
\hline 252 & & 113 非六 \\
\cline { 1 - 1 } & & 56 \\
\cline { 1 - 1 }$(673)$ & 244 & 76
\end{tabular}

(684)

\begin{tabular}{|c|c|c|c|}
\hline$(665)$ & 268 & 78 & \\
\hline$(630)$ & 558 & 96 & \\
\hline (610) & $(673)$ & 134 & \\
\hline (585) & $(652)$ & 200 & \\
\hline \multirow[t]{4}{*}{$(576)$} & $(634)$ & 324 & \\
\hline & & $(676)$ & 66 \\
\hline & & (664) & 84 \\
\hline & & (653) & 112 \\
\hline
\end{tabular}


Table 5B. Effect of Vent Size on Time and Energy Needed to Achieve Flashover Room size: length $3.66 \mathrm{~m}$, width $=5.49 \mathrm{~m}$, height $=2.44 \mathrm{~m}$

Vent Characteristics

Steady State Energy Output (MW)

$\begin{array}{ccc}\begin{array}{c}\text { Vent (Door) } \\ \text { Width }\end{array} & \begin{array}{c}\text { Vent } \\ \text { Width } \\ \text { (\% of room length) }\end{array} & \text { A(h) })^{1 / 2} \\ 10 & 0.37 & 1.1 \\ 20 & 0.73 & 2.1 \\ 21^{\mathrm{s}} & 0.76 & 2.2 \\ 30 & 1.10 & 3.2 \\ 40 & 1.46 & 4.2 \\ 50 & 1.83 & 5.3 \\ 60 & 2.19 & 6.3 \\ 70 & 2.56 & 7.4 \\ 80 & 2.93 & 8.5 \\ 90 & 3.29 & 9.5 \\ 100 & 3.66 & 10.6\end{array}$

$\begin{array}{lllll}0.98 & 1.23 & 1.48 & 1.72 & 1.97\end{array}$

\begin{tabular}{|c|c|c|c|c|}
\hline 900 & 304 & & \multirow[b]{4}{*}{146} & \\
\hline & 708 & & & \\
\hline & 772 & & & \\
\hline & $(774)$ & 412 & & \\
\hline & (751) & 788 & 208 & \\
\hline & $(736)$ & $(786)$ & 302 & \\
\hline & $(724)$ & & 430 & \\
\hline & (715) & & 628 & \\
\hline & $(622)$ & & $(720)$ & 192 \\
\hline & $(702)$ & & (711) & 230 \\
\hline & $(697)$ & & $(786)$ & 282 \\
\hline
\end{tabular}


Table 5C. Effect of Vent Size on Time and Energy Needed to Achieve Flashover Room size: length $=4.88 \mathrm{~m}$, width $=7.32 \mathrm{~m}$, height $=2.44 \mathrm{~m}$

Vent Characteristics

Steady State Energy Output (MW)

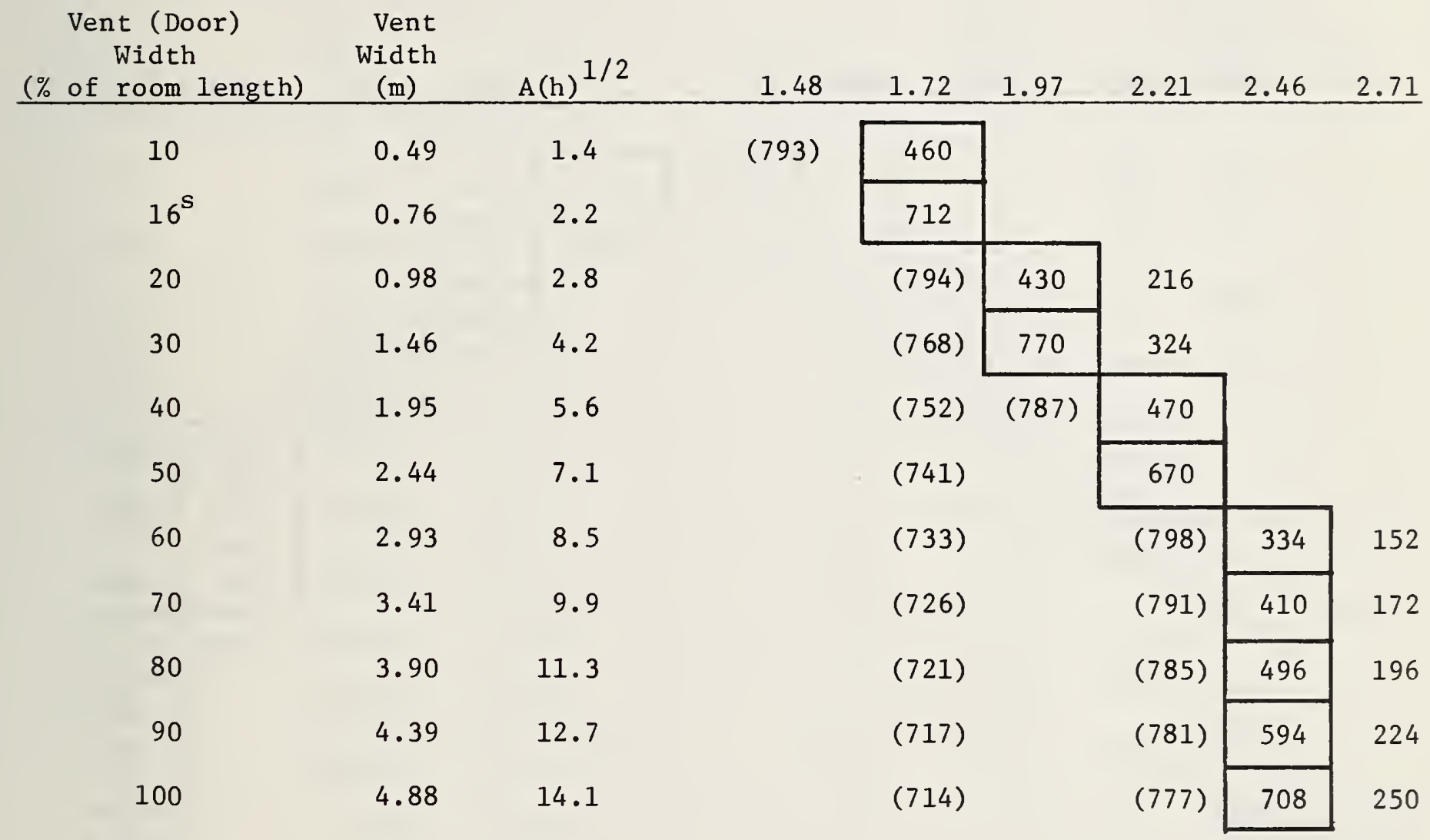


Table 5D. Effect of Vent Size on Time and Energy Needed to Achieve Flashover Room size: length $=6.10 \mathrm{~m}$, width $=9.14 \mathrm{~m}$, height $=2.44 \mathrm{~m}$

Vent Characteristics

Steady State Energy Output (MW)

\begin{tabular}{|c|c|c|}
\hline $\begin{array}{c}\text { Vent (Door) } \\
\text { Width } \\
\text { (\% of room length) }\end{array}$ & $\begin{array}{l}\text { Vent } \\
\text { Width } \\
\text { (m) }\end{array}$ & $A(h)^{1}$ \\
\hline 10 & 0.61 & 1.8 \\
\hline $12^{\mathrm{s}}$ & 0.76 & 2.2 \\
\hline 20 & 1.22 & 3.5 \\
\hline 30 & 1.83 & 5.3 \\
\hline 40 & 2.44 & 7.1 \\
\hline 50 & 3.05 & 8.8 \\
\hline 60 & 3.66 & 10.6 \\
\hline 70 & 4.27 & 12.4 \\
\hline 80 & 4.88 & 14.1 \\
\hline 90 & 5.49 & 15.9 \\
\hline 100 & 6.10 & 17 \\
\hline
\end{tabular}

2.21

2.46

2.71

2.95

3.20

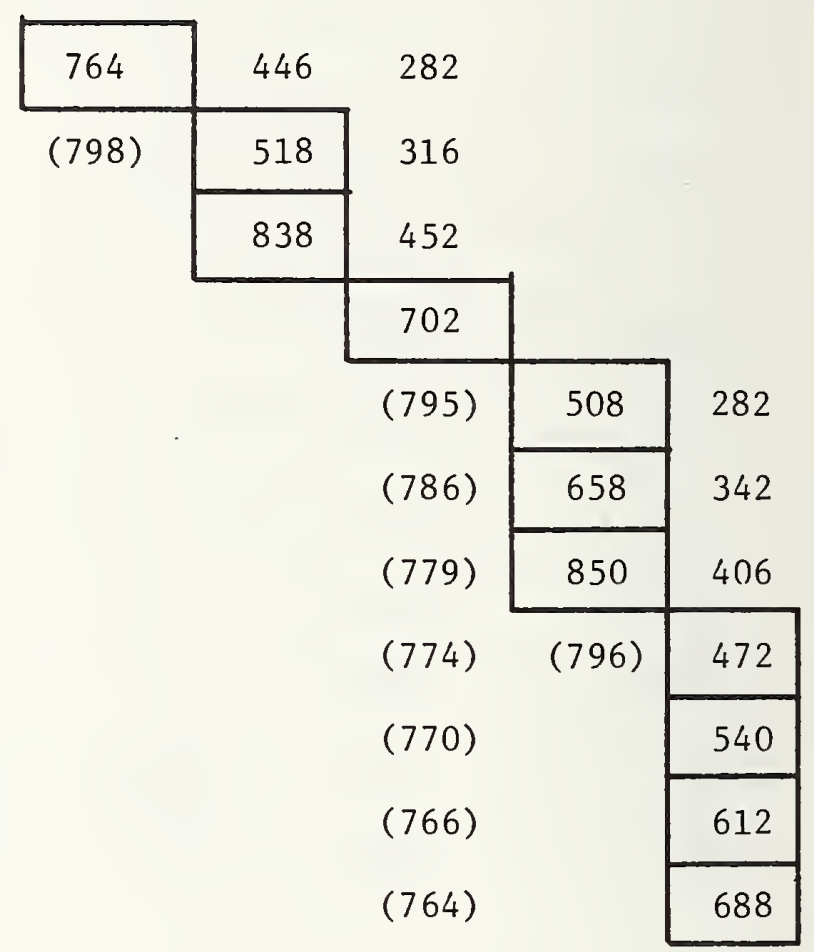


Table 5E. Effect of Vent Size on Time and Energy Needed to Achieve Flashover Room size: length $=7.32 \mathrm{~m}$, width $=10.97 \mathrm{~m}$, height $=2.44 \mathrm{~m}$

Vent Characteristics

Steady State Energy Output (MW)

Vent (Door)

Width

(\% of room length)

$\begin{array}{lll}10 & 0.73 & 2.1 \\ 10^{\mathrm{s}} & 0.76 & 2.2 \\ 20 & 1.46 & 4.2 \\ 30 & 2.19 & 6.3 \\ 40 & 2.93 & 8.5 \\ 50 & 3.66 & 10.6 \\ 60 & 4.39 & 12.7 \\ 70 & 5.12 & 14.8 \\ 80 & 5.85 & 16.9 \\ 90 & 6.58 & 19.1 \\ 100 & 7.32 & 21.2\end{array}$

2.95

3.20

3.44

3.69

3.94

4.18

\begin{tabular}{|c|c|c|c|c|c|}
\hline 822 & 532 & & $462 *$ & & \\
\hline 850 & \multicolumn{2}{|l|}{546} & \multicolumn{3}{|l|}{$392 \%$} \\
\hline & (798) & 572 & \multicolumn{3}{|l|}{378} \\
\hline & $(782)$ & 866 & \multicolumn{3}{|l|}{516} \\
\hline & \multirow[t]{7}{*}{ (773) } & \multirow[t]{7}{*}{ (791) } & 670 & & \\
\hline & & & 858 & & . \\
\hline & & & $(796)$ & 572 & 352 \\
\hline & & & (792) & 654 & 390 \\
\hline & & & $(788)$ & 740 & 426 \\
\hline & & & $(786)$ & 834 & 462 \\
\hline & & & (783) & (799) & 496 \\
\hline
\end{tabular}




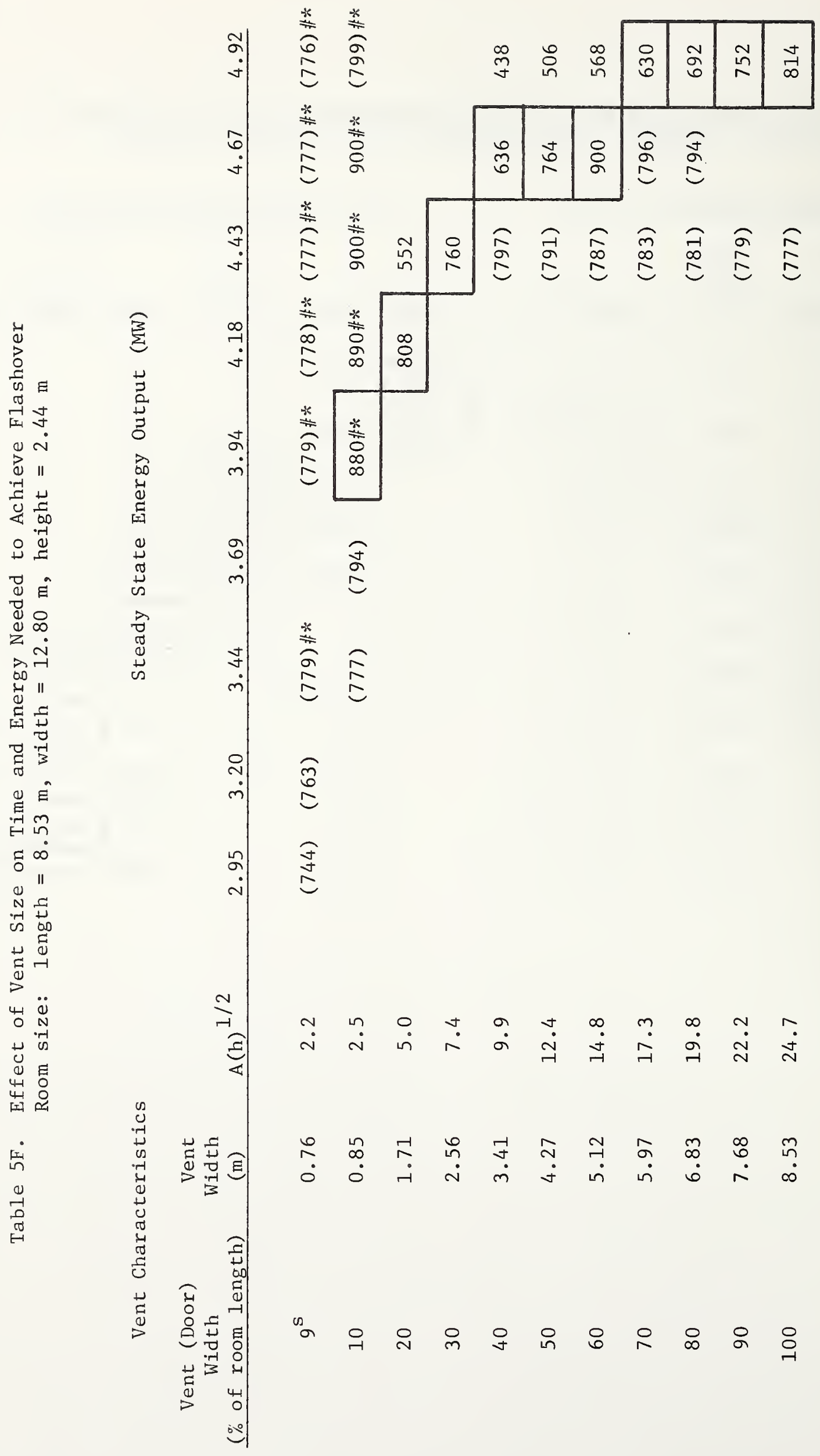


Table 5G. Effect of Vent Size on Time and Energy Needed to Achieve Flashover Room size: length $=1.83 \mathrm{~m}$, width $=1.83 \mathrm{~m}$, height $=2.44 \mathrm{~m}$

Vent Characteristics

Steady State Energy Output (MW)

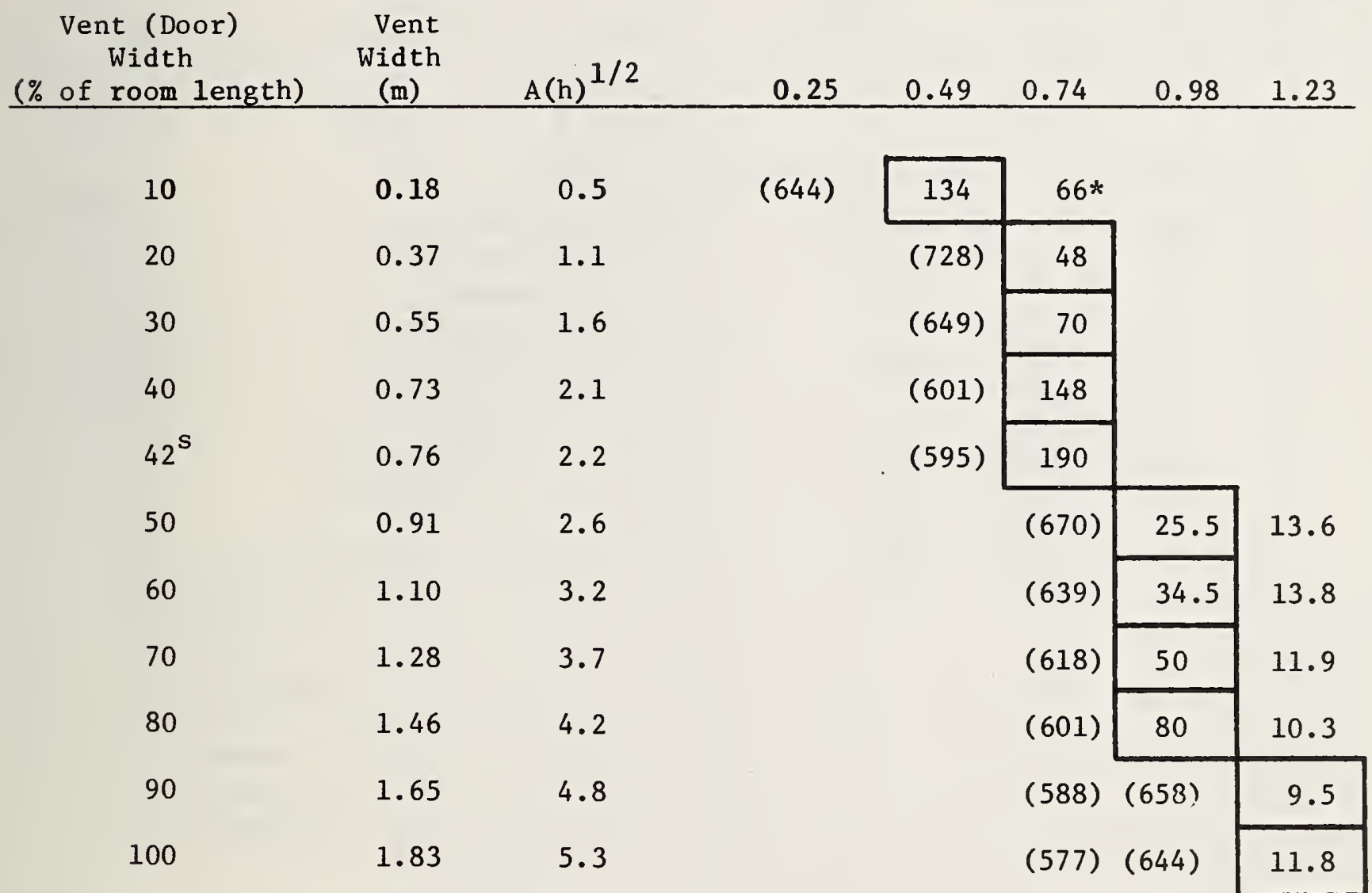


Table 5H. Effect of Vent Size on Time and Energy Needed to Achieve Flashover Room size: length $=1.83 \mathrm{~m}$, width $=9.14 \mathrm{~m}$, height $=2.44 \mathrm{~m}$

Vent Characteristics

Steady State Energy Output (MW)

Vent (Door) Vent

Width Width

(\% of room length)

(m)

$A(h)^{1 / 2}$

0.98

1.23

1.48

1.72

1.97

$\begin{array}{lll}10 & 0.18 & 0.5 \\ 20 & 0.37 & 1.1 \\ 30 & 0.55 & 1.6 \\ 40 & 0.73 & 2.1 \\ 42^{\mathrm{S}} & 0.76 & 2.2 \\ 50 & 0.91 & 2.6 \\ 60 & 1.10 & 3.2 \\ 70 & 1.28 & 3.7 \\ 80 & 1.46 & 4.2 \\ 90 & 1.65 & 4.8 \\ 100 & 1.83 & 5.3\end{array}$

\begin{tabular}{|c|c|c|c|c|}
\hline 702非* & & \multicolumn{2}{|l|}{ 736非* } & (746) 非* \\
\hline 760 & & \multicolumn{2}{|l|}{140} & 92.5 非 \\
\hline$(776)$ & 400 & \multicolumn{2}{|l|}{168} & 64 \\
\hline$(751)$ & 596 & \multicolumn{2}{|l|}{208} & 68 \\
\hline$(747)$ & 642 & \multicolumn{2}{|l|}{216} & 68 \\
\hline$(732)$ & (718) & 266 & & 72 \\
\hline \multirow[t]{5}{*}{$(718)$} & (711) & 346 & & 76 \\
\hline & & $(732)$ & 154 & 82 \\
\hline & & $(718)$ & 178 & 86 \\
\hline & & $(706)$ & 206 & 92 \\
\hline & & $(696)$ & 238 & 98 \\
\hline
\end{tabular}


Table 5I. Effect of Vent Size on Time and Energy Needed to Achieve Flashover Room size: length $=1.83 \mathrm{~m}$, width $=12.19 \mathrm{~m}$, height $=2.44 \mathrm{~m}$

Vent Characteristics

Steady State Energy Output (MW)

Vent (Door)

Width

(\% of room length)

10

20

30

40

$42^{\mathrm{s}}$

50

60

70

80

90

100
0.18

0.5

$0.37^{\prime} \quad 1.1$

0.55

1.6

0.73

2.1

0.76

2.2

0.91

2.6

1.10

3.2

1.28

3.7

1.46

4.2

1.65

4.8

1.83

5.3
0.98

1.23 1.48 $1.72 \quad 1.97$ 2.21

\begin{tabular}{|c|c|c|c|}
\hline (754) 非* (753) 非 & & (748) 非* & \\
\hline 672 & & 185非* & \\
\hline (791) & 418 & 210 & \\
\hline (769) & 562 & 252 & \\
\hline$(766)$ & 592 & 260 & \\
\hline$(752)$ & 782 & 308 & \\
\hline (739) & $(719)$ & 378 & \\
\hline & & $(756)$ & 196 \\
\hline & & (744) & 222 \\
\hline & & (733) & 248 \\
\hline & & (725) & 286 \\
\hline
\end{tabular}




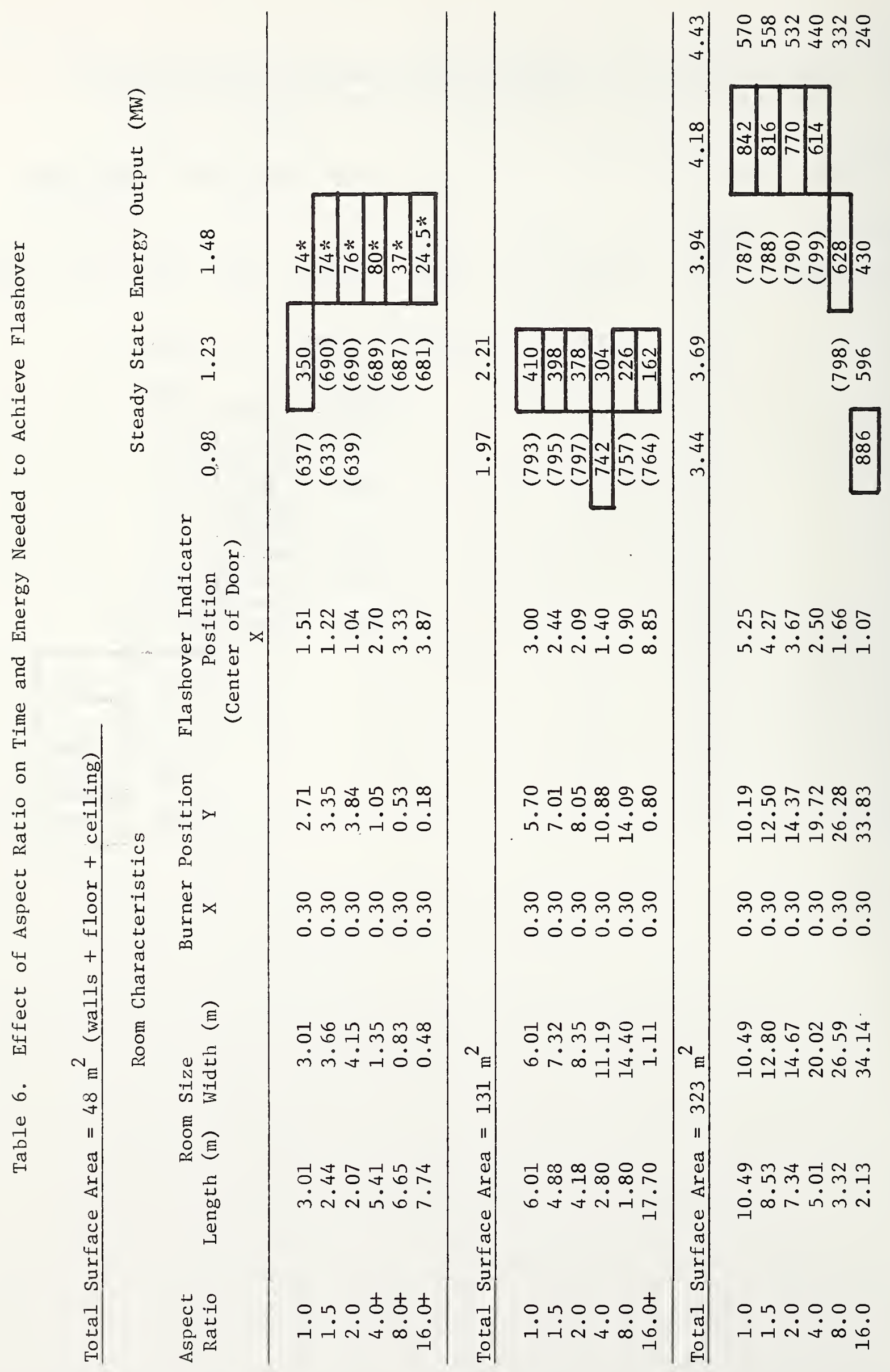



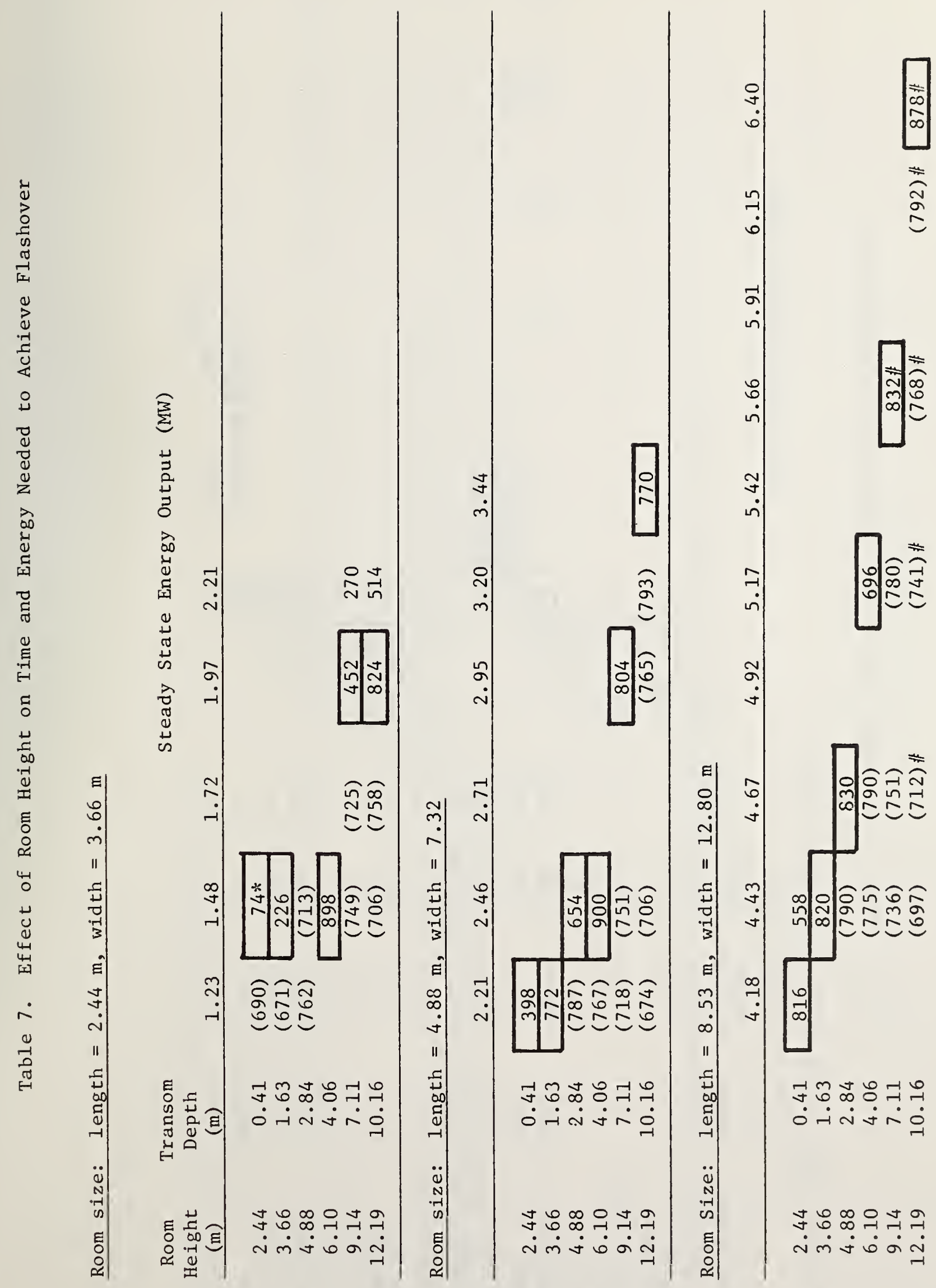


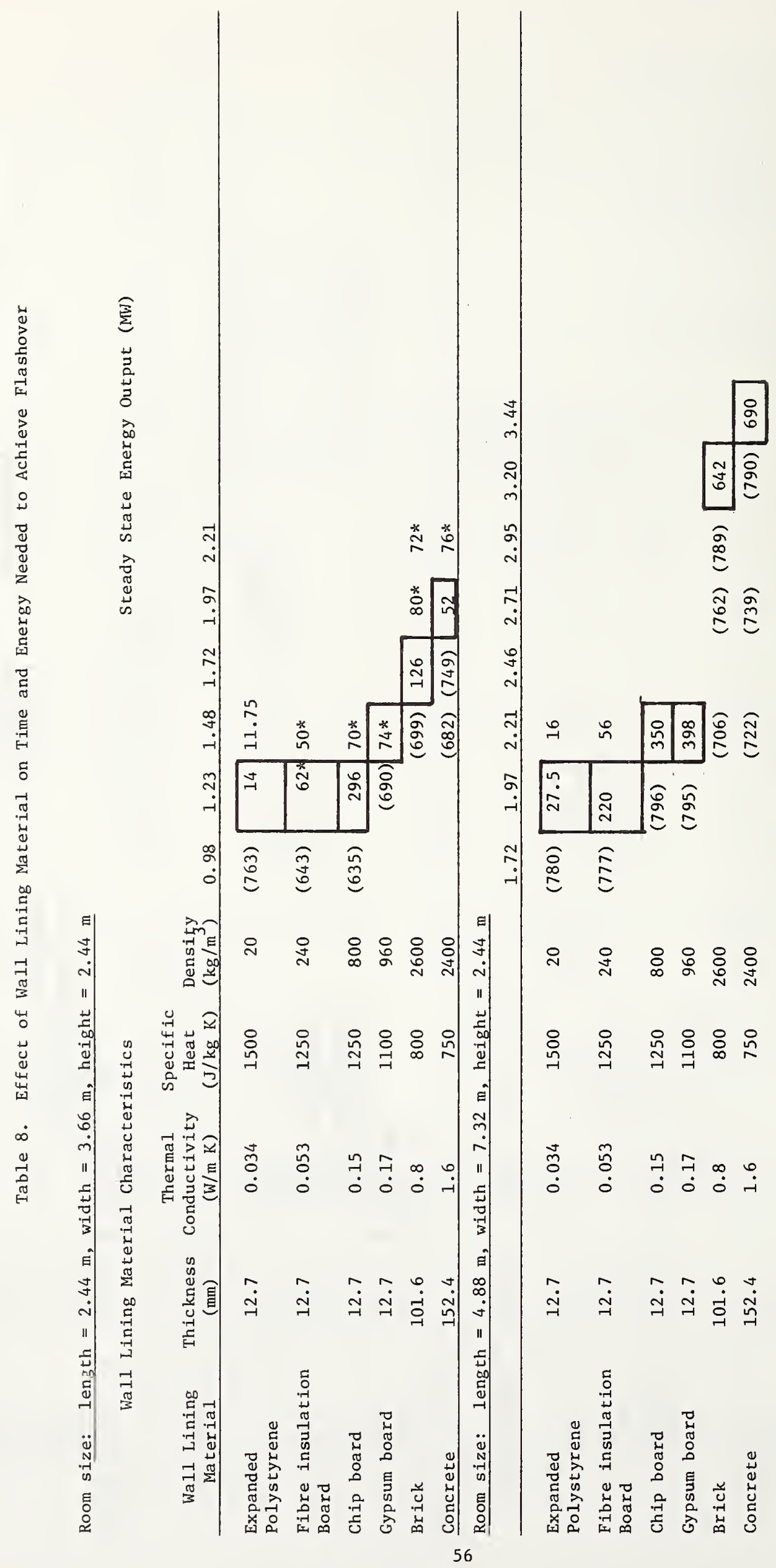




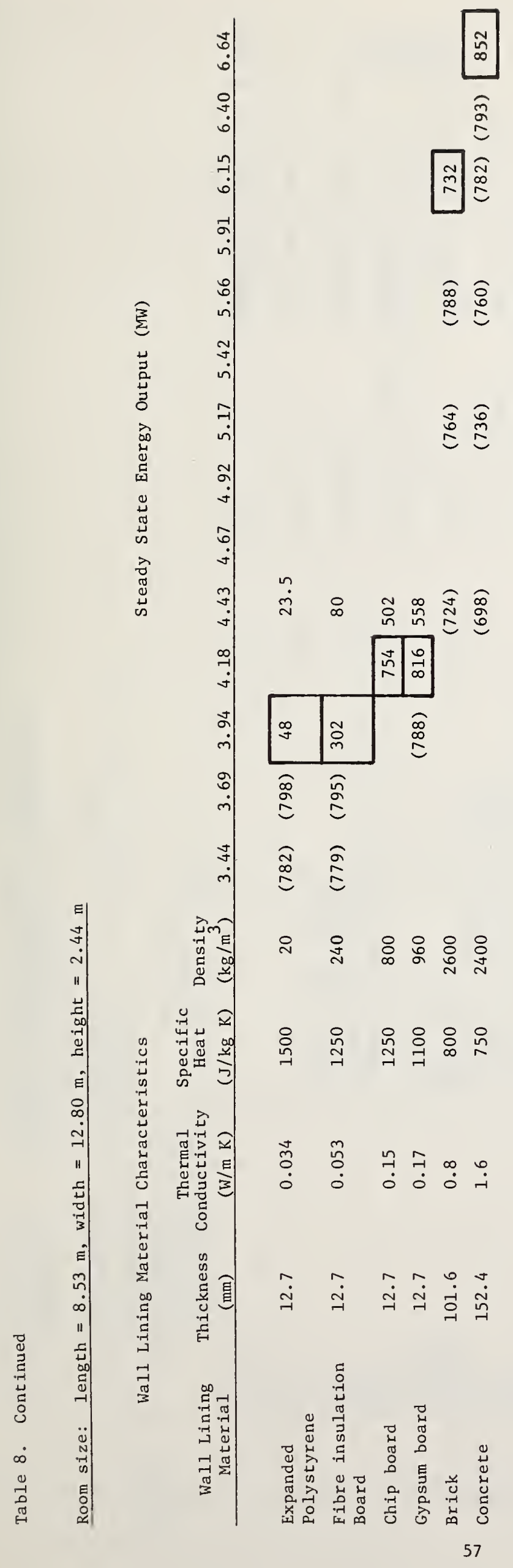




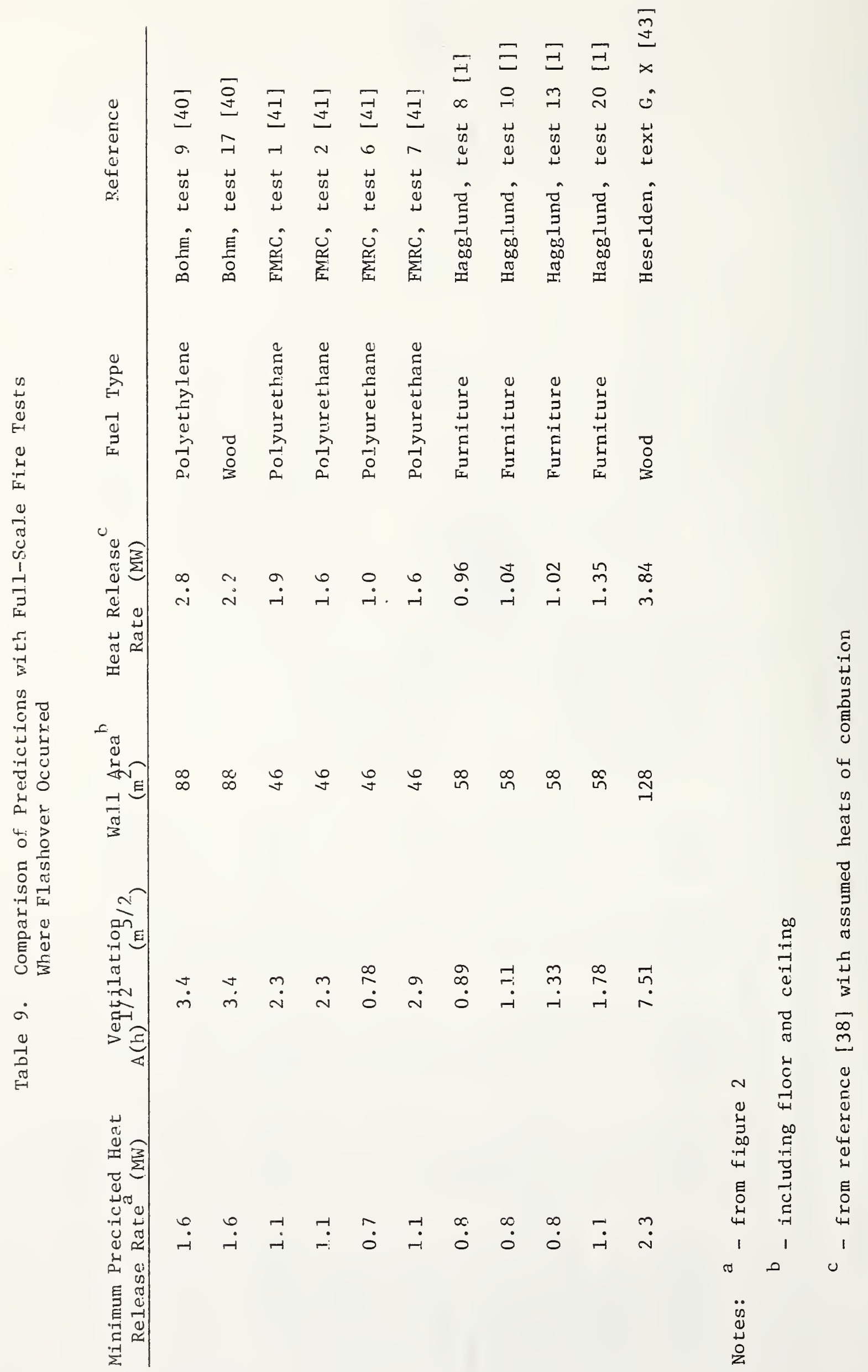


APPENDIX A

Uี

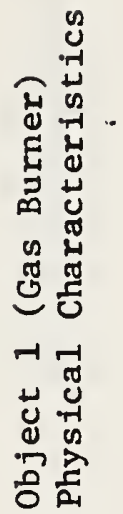

E

Iำ

चु u

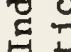

4

3

논

(⿻)

齐

N

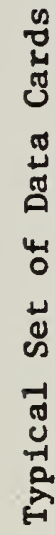

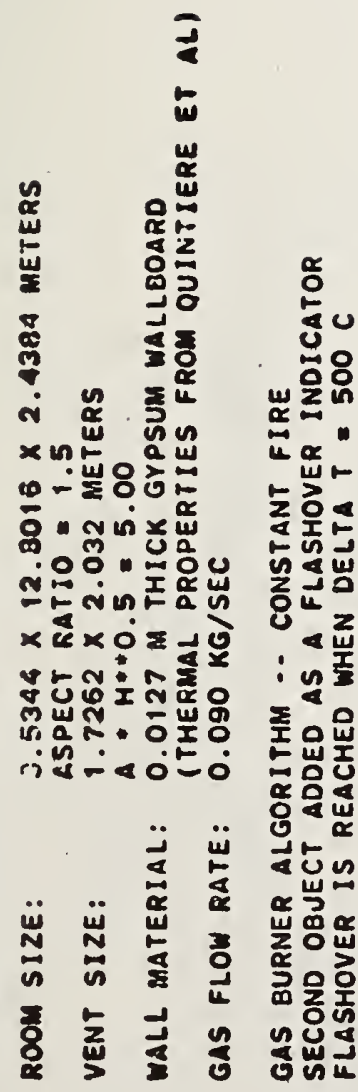
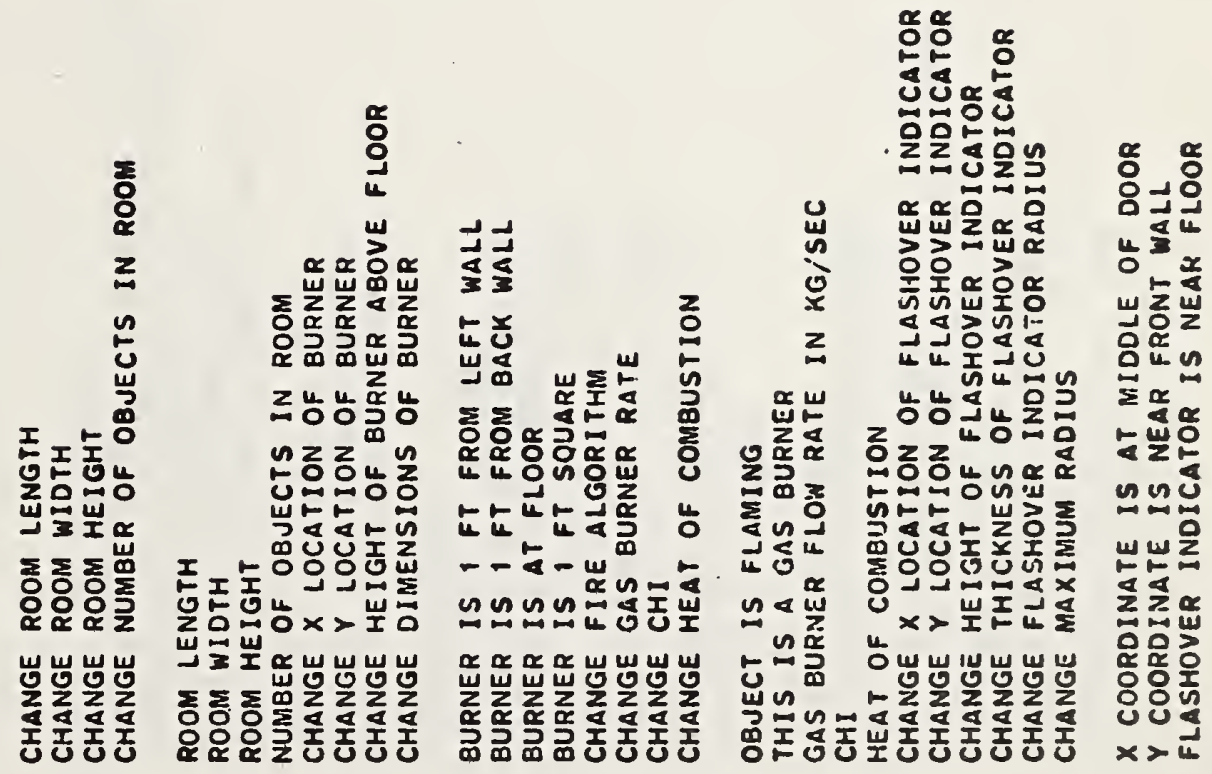

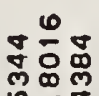

串这

¿̊

นกั

ल०0 - 0 \%

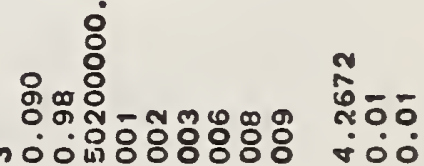

总范

- 


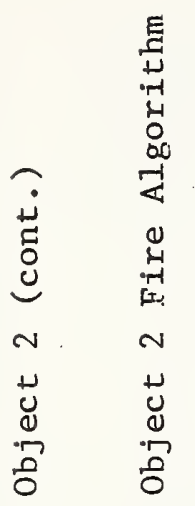

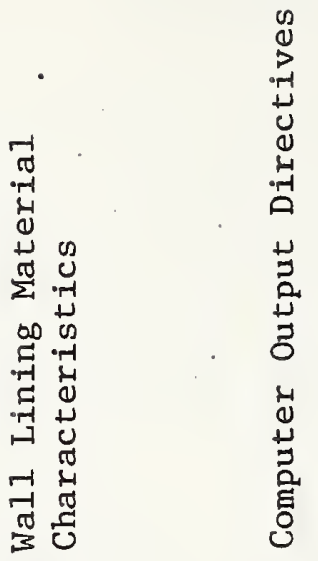
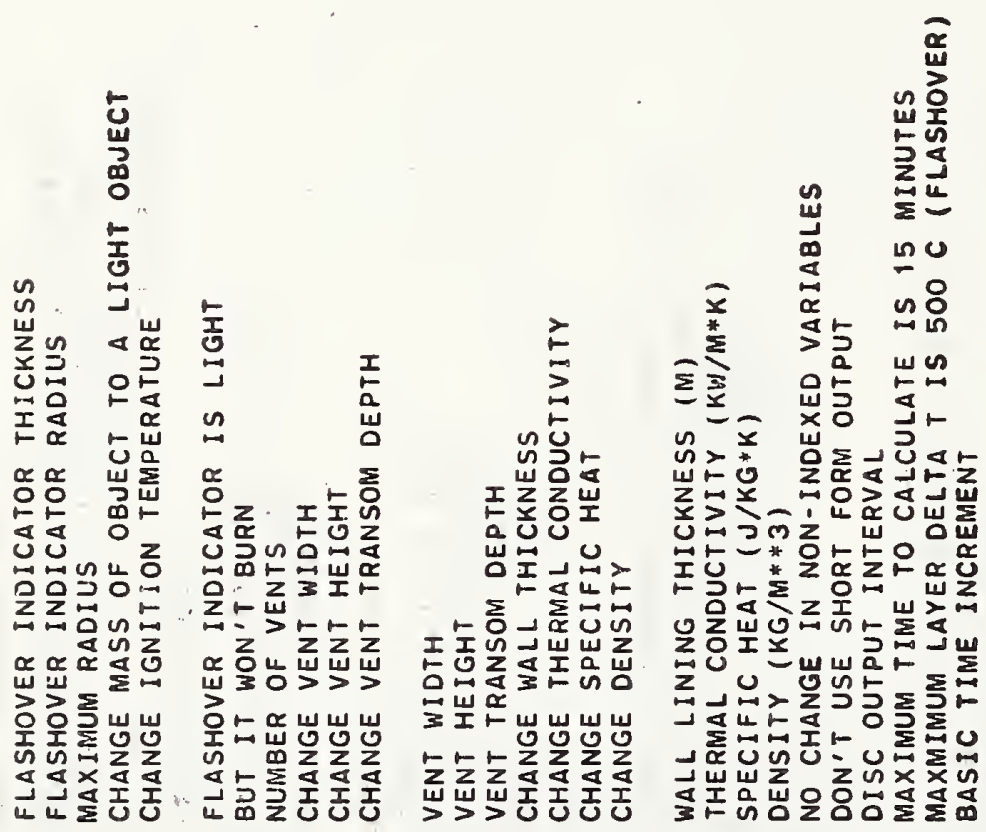

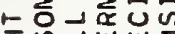

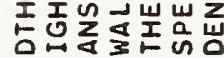

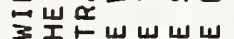

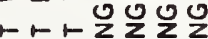

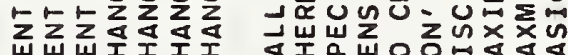

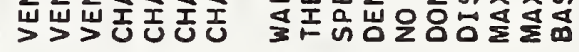

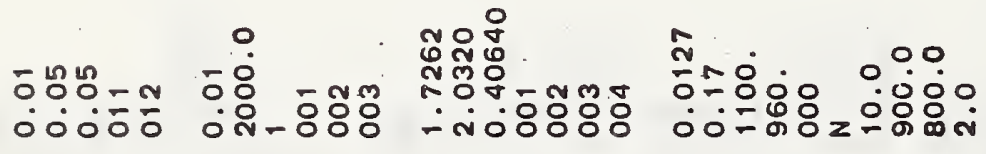

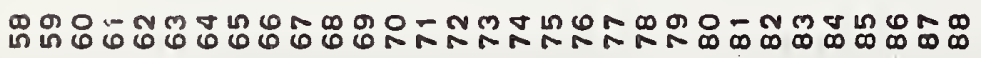


岂

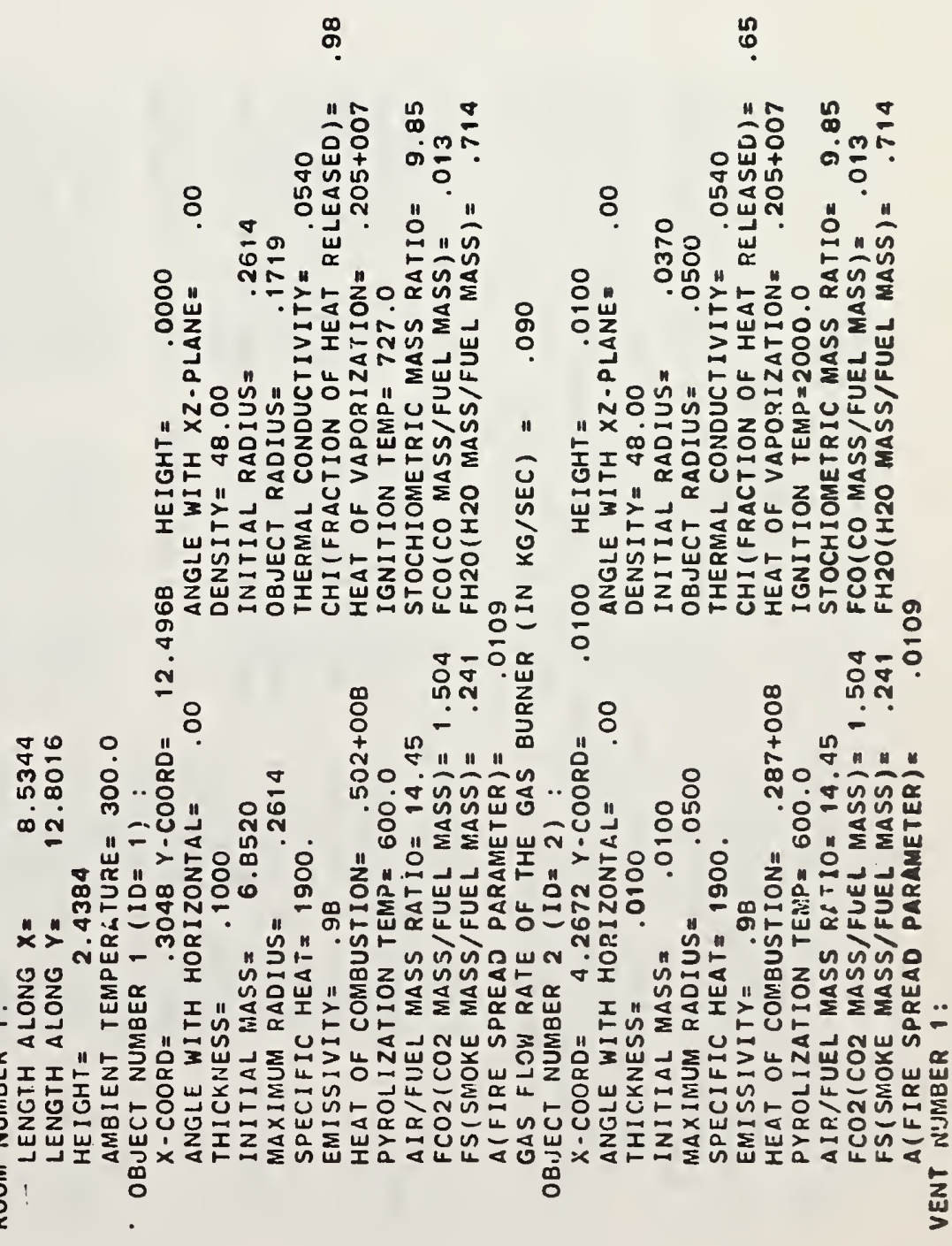




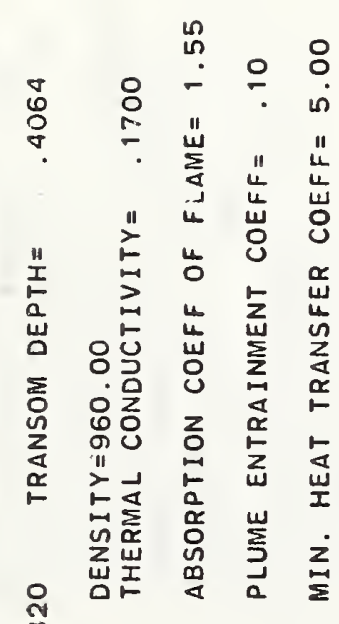

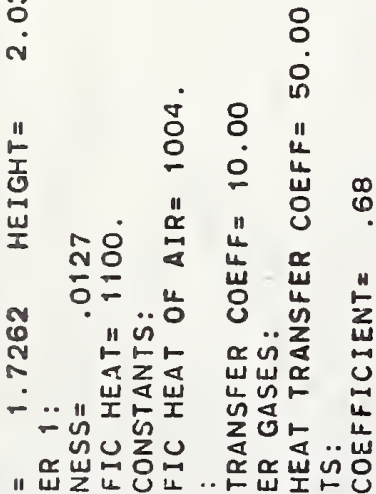

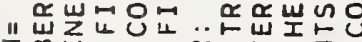

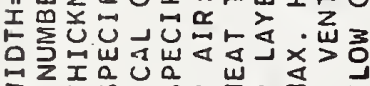

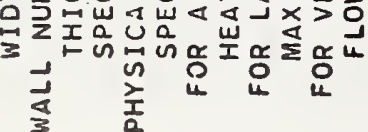

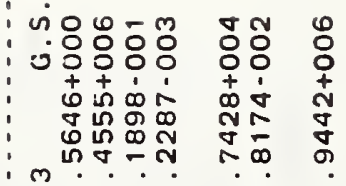

लिलंत- लं- -

"

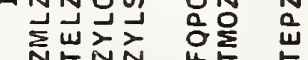

minenuna

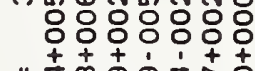

"I

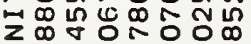

$\dot{\nabla} \dot{\nabla} \dot{\theta}-\dot{\sigma} \dot{\theta}$

"

NNNNN

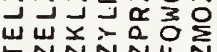

"

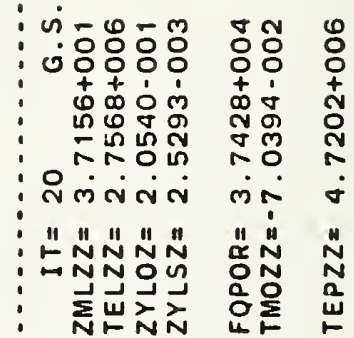

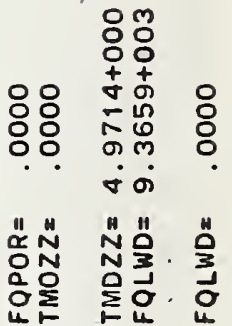

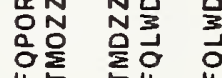

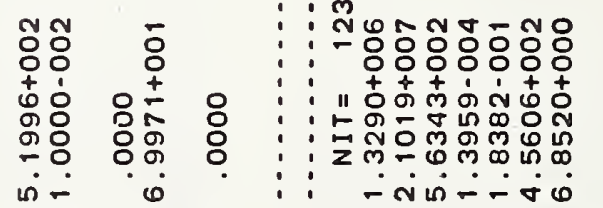

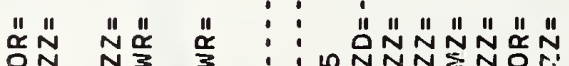

ํํㅇํํำ융

市安

ํํㅇำ

in- $\dot{\text { i }}$

8

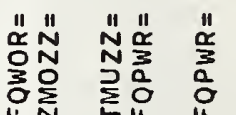

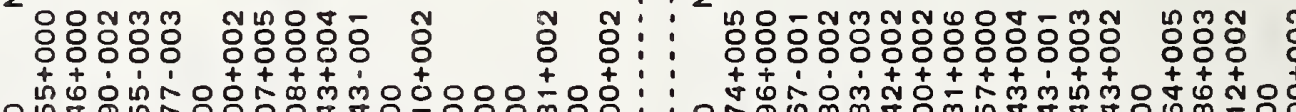

(1)

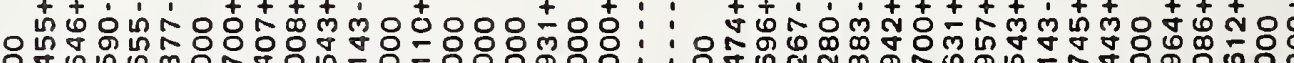

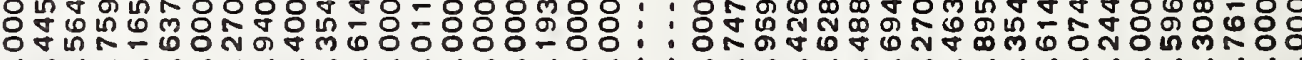

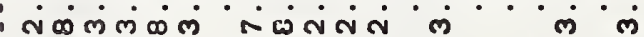

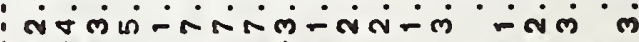

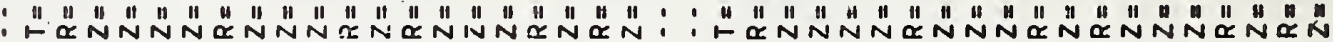
OLNNN

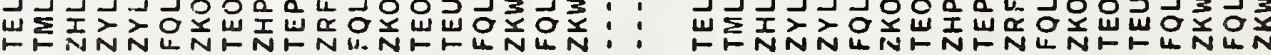

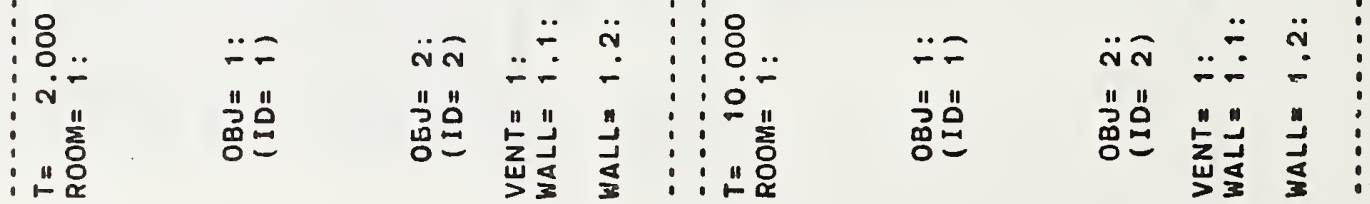




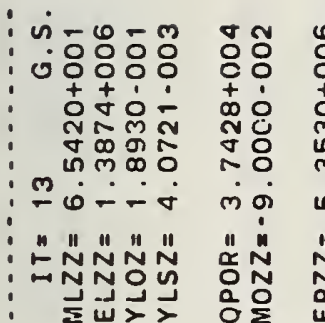

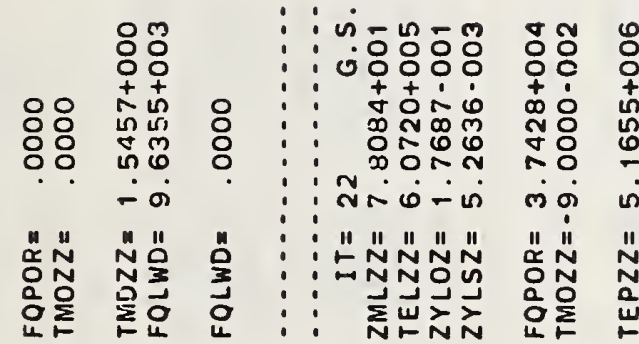

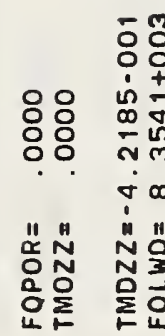

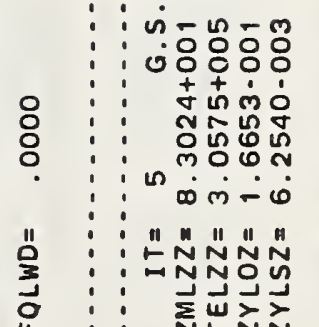

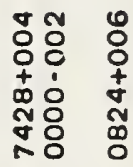

突出交

인

สิํํㅇํํํํํํํํํํํำ

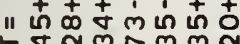

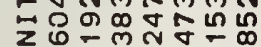

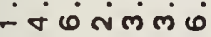

" " " " " " "

ONNN㢳N

ㅇNNㅗN요

山س

"I

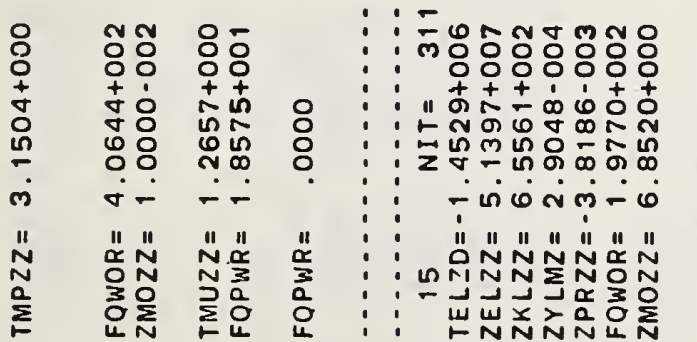

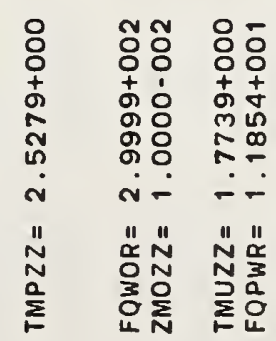

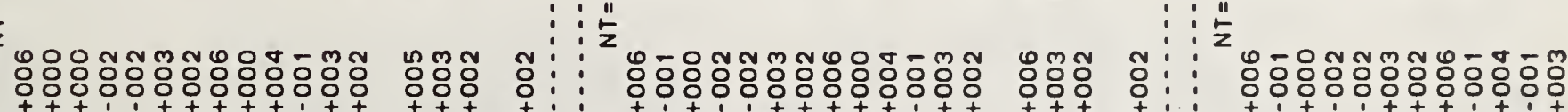

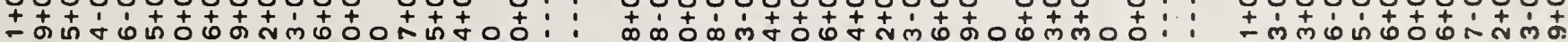

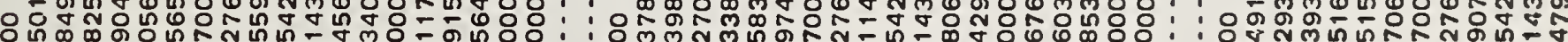

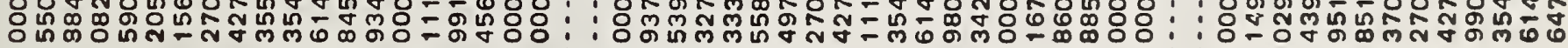

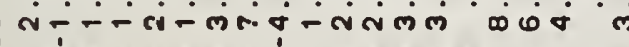
in-n-m-dnd

$-\infty \dot{0}$

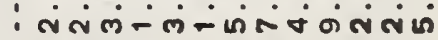

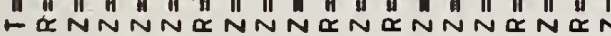

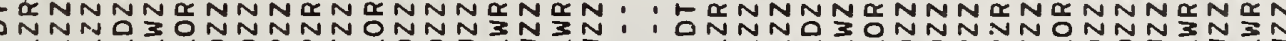

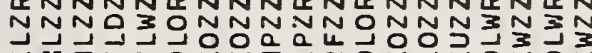

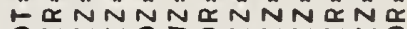
: ONNNOBONNNNNO

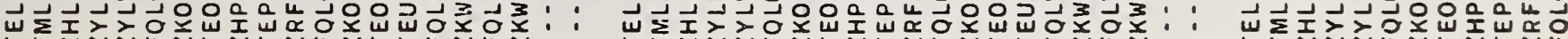




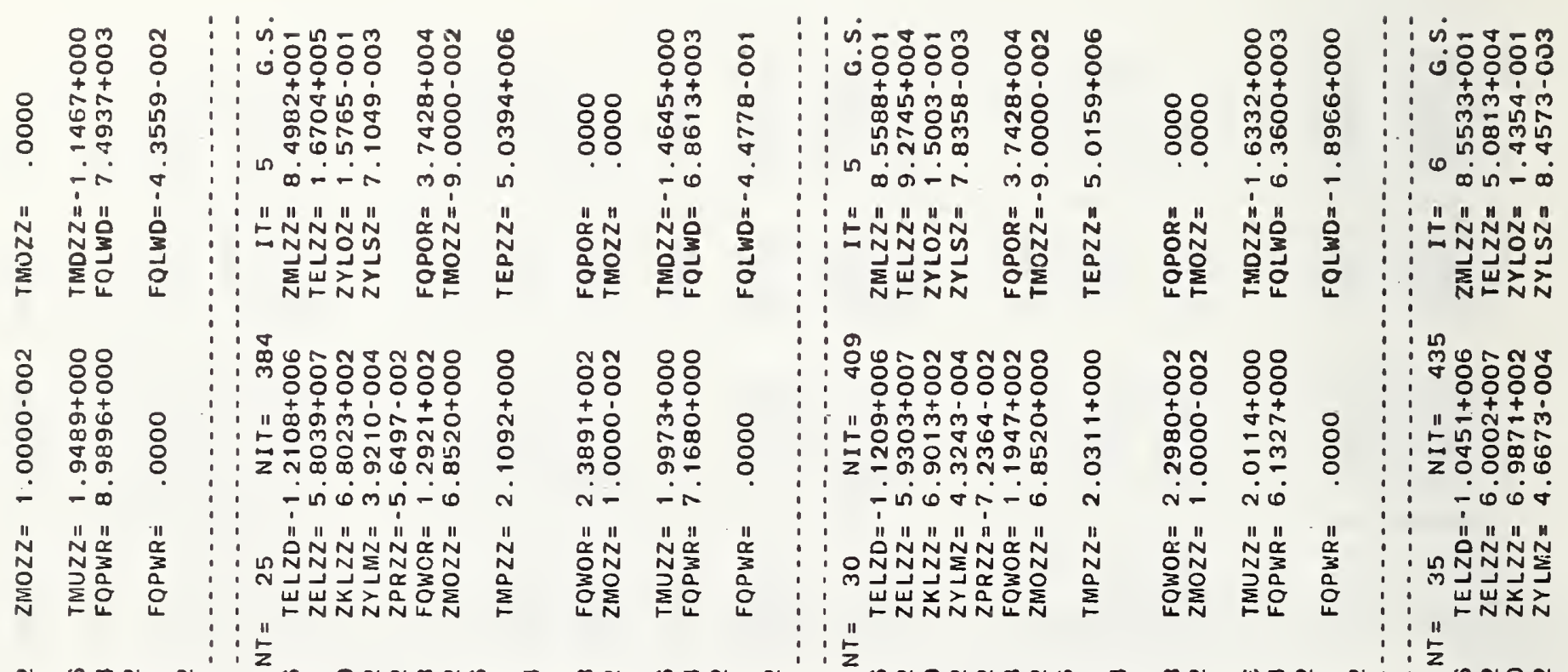

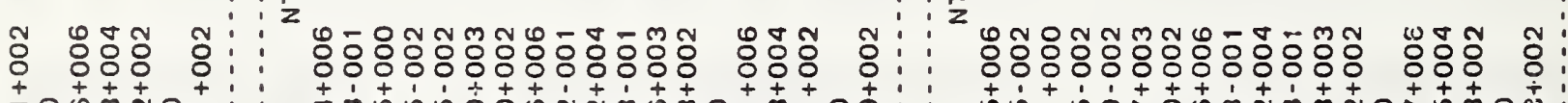

ํํํํํํํํำ

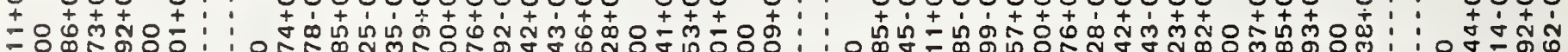

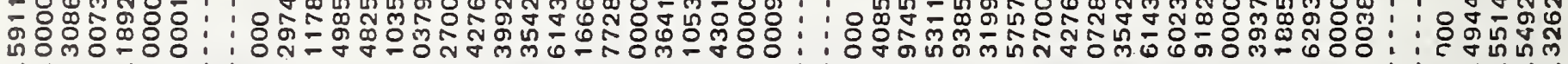
-

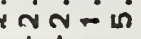

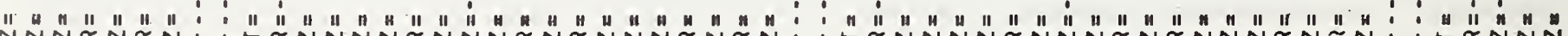
NNN年 OOD

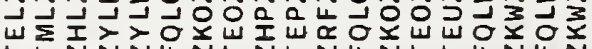

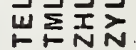

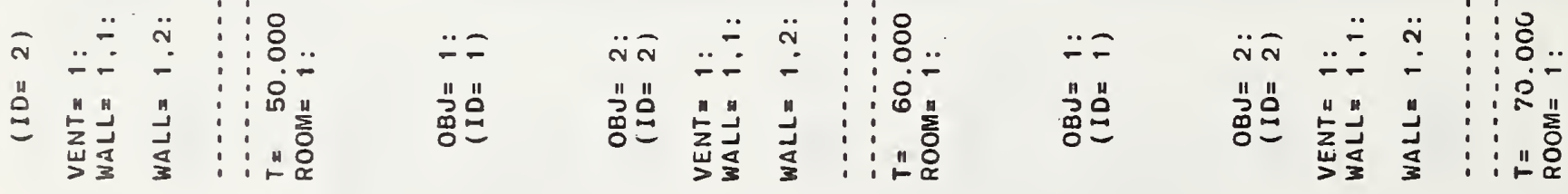




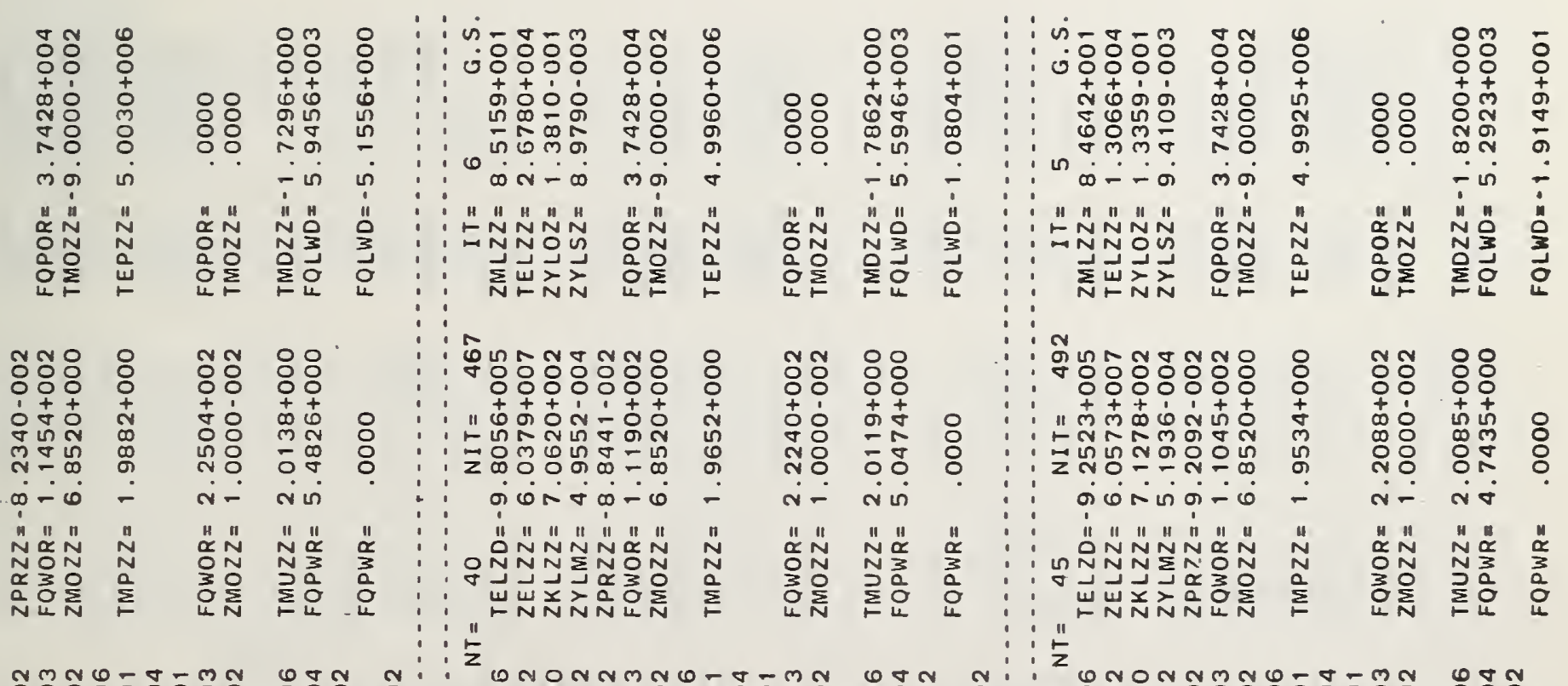

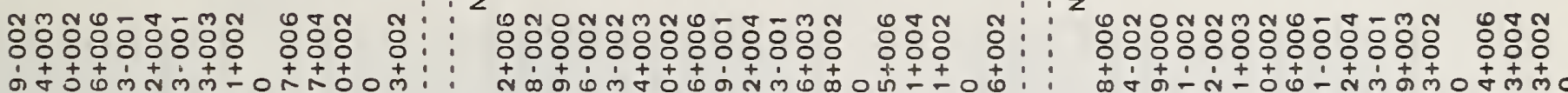

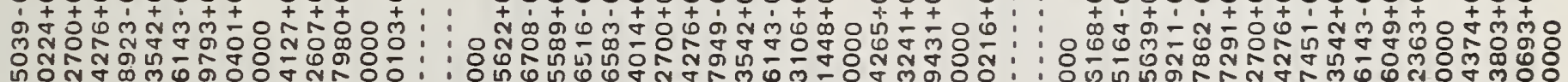

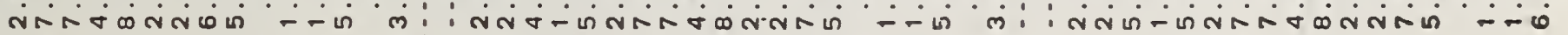

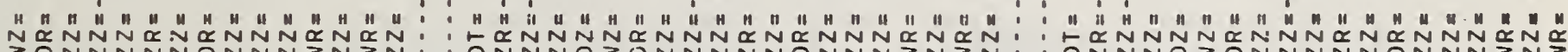

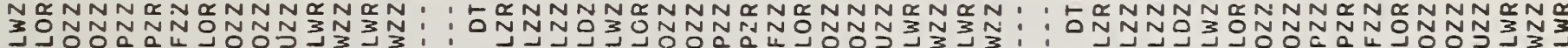

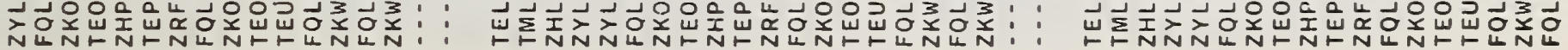

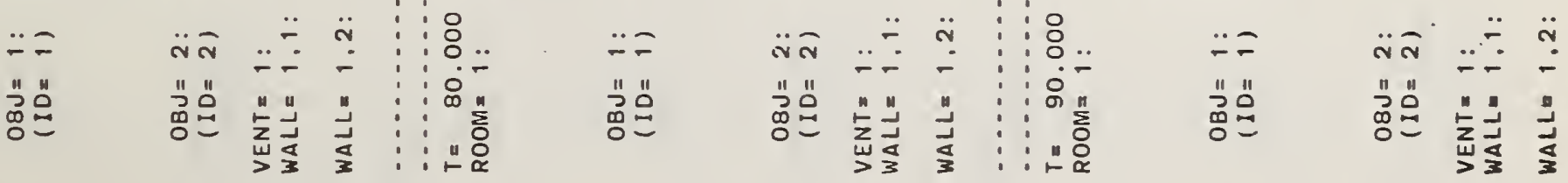



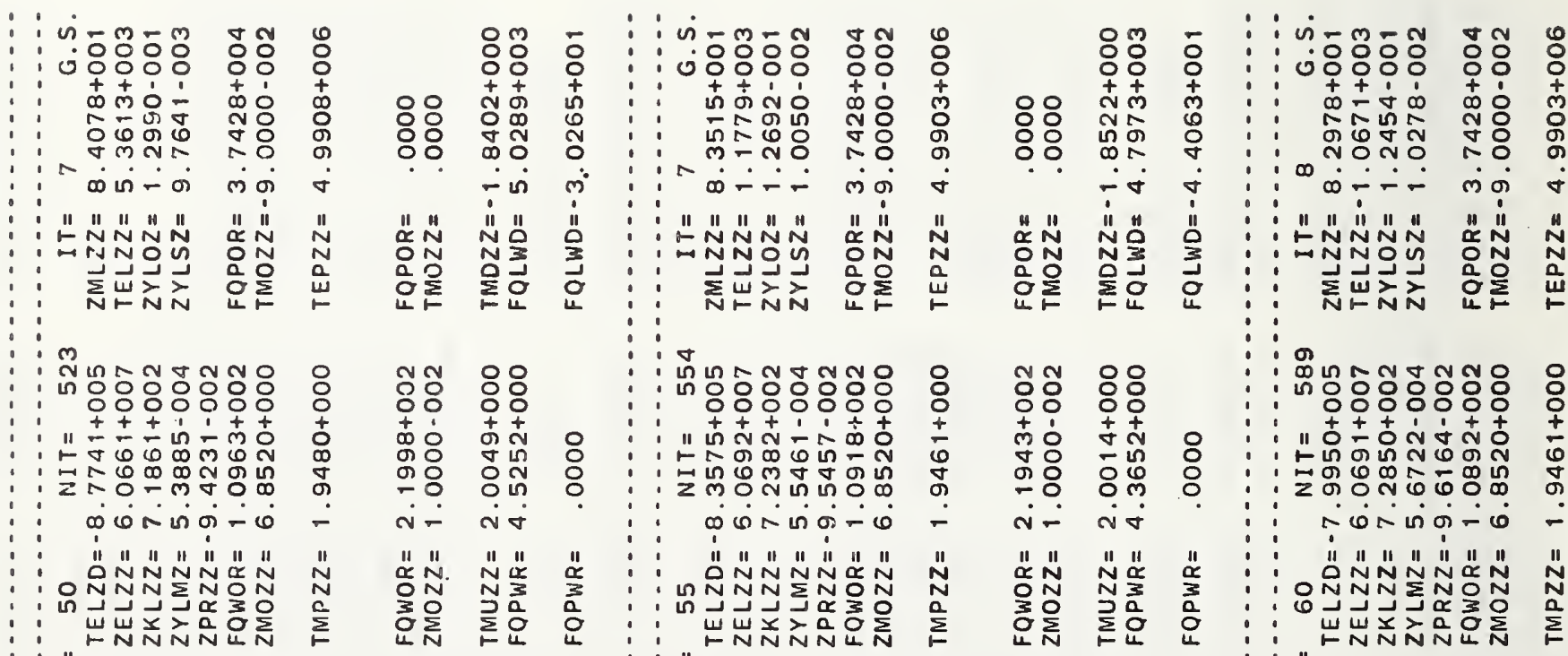
$: \frac{11}{2}$

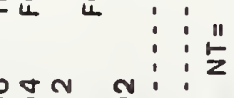

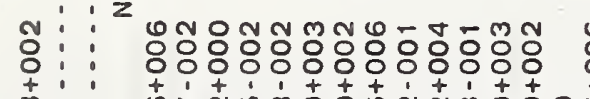

\section{(1)}

(1)

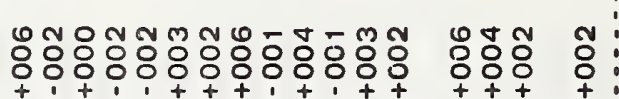

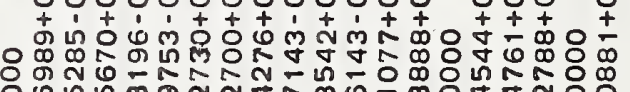

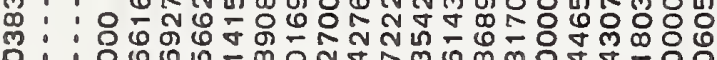

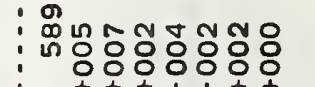

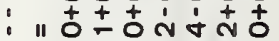
ᄂ

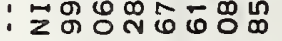
$\therefore \dot{0} \dot{0} \dot{0}-\dot{0}$ :

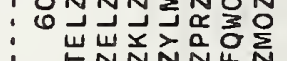

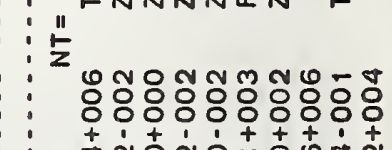

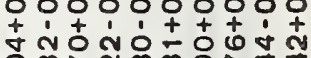

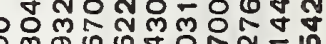
o: : i

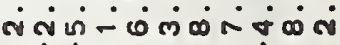

": " " " " " | " | " N: :

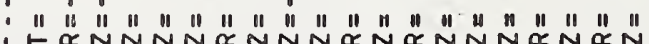

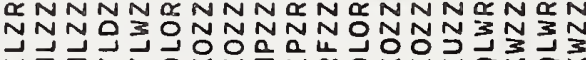

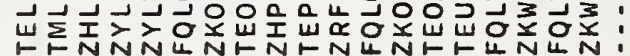

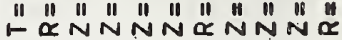

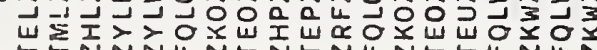

NNNOZONNNN

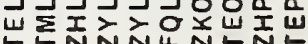

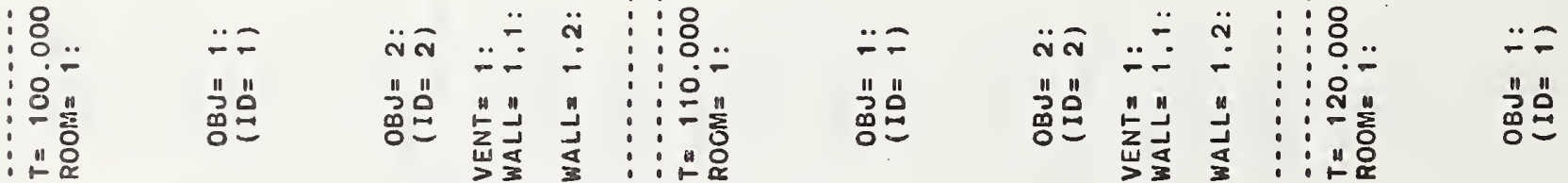




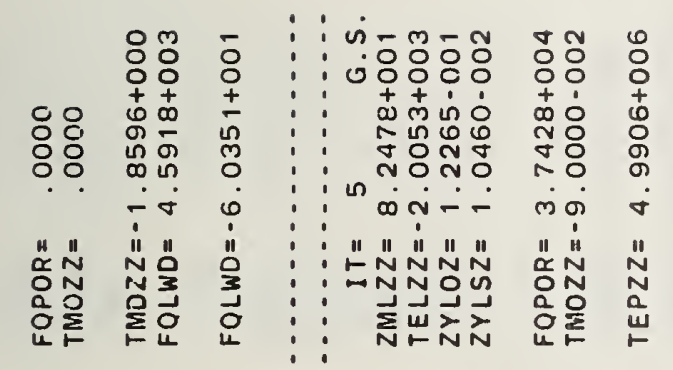

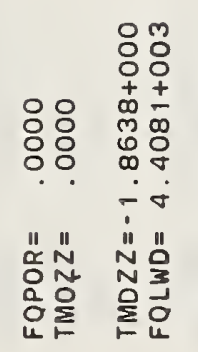

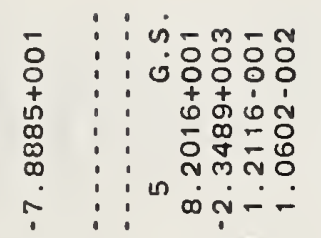

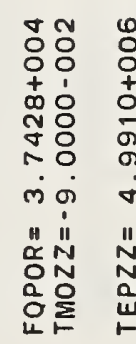

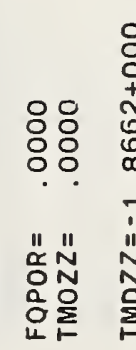

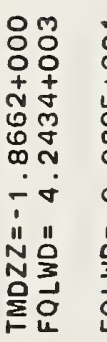

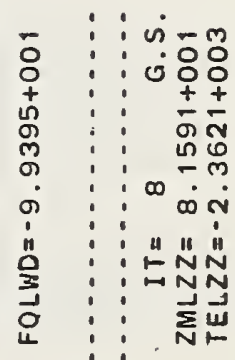

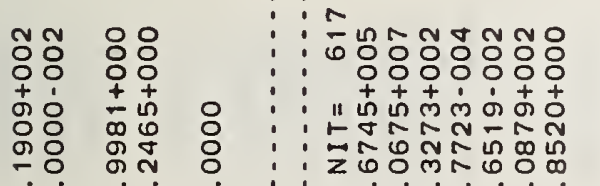

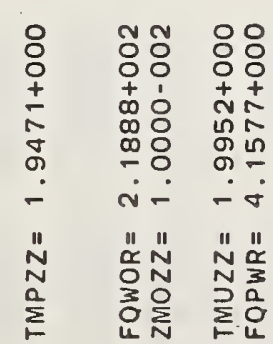
응ำ
$\circ: 11+\infty$

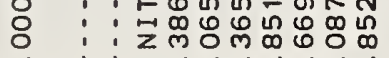 : un
$\frac{\alpha}{3}$
$\frac{1}{a}$
0
0 $\vdots \vdots$ :

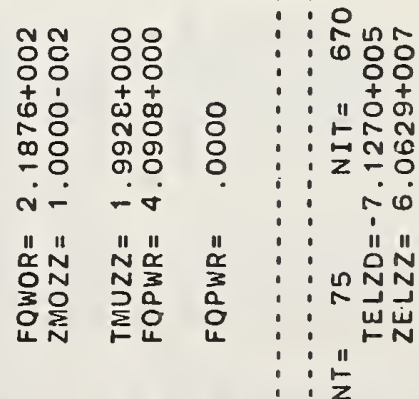

รีํํㅇ

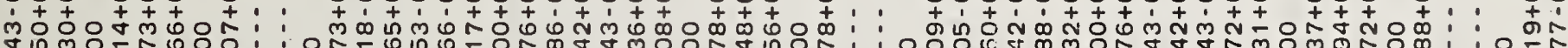

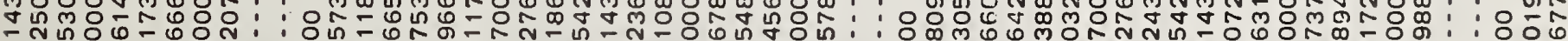
ঢ ता ம " " " " " " "

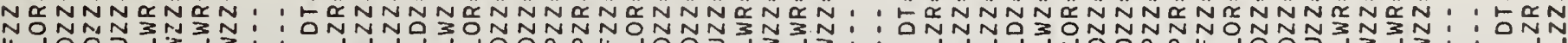

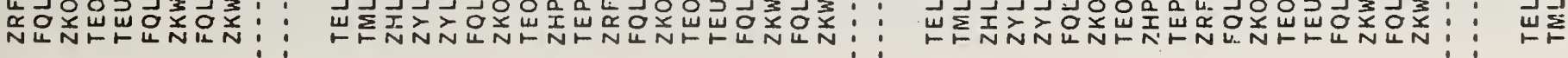

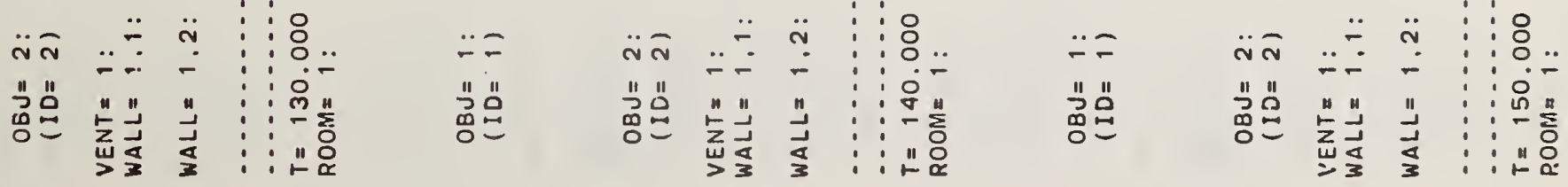




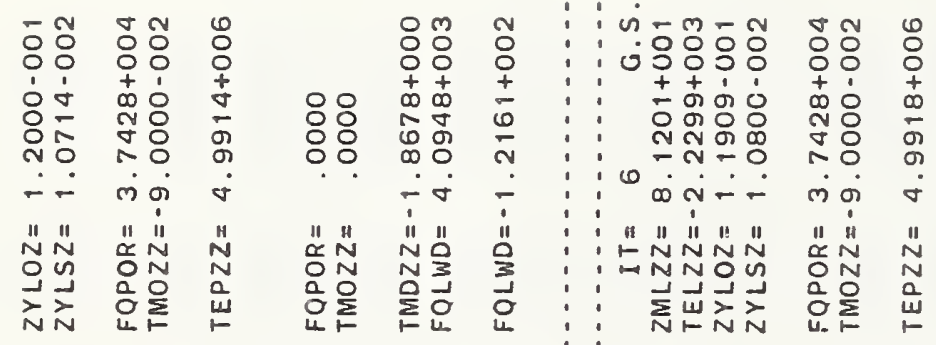

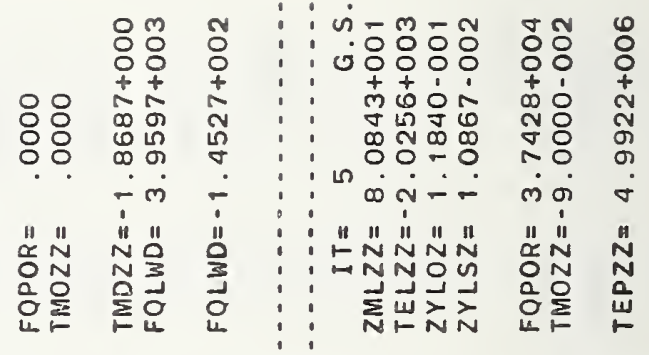

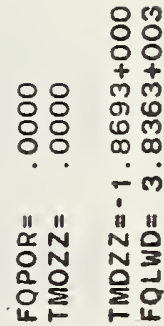

\begin{tabular}{|c|c|c|}
\hline 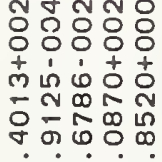 & 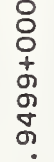 & 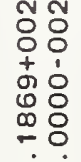 \\
\hline $9-6$ & - & $N-$ \\
\hline 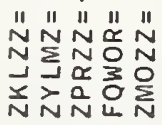 & $\begin{array}{l}\stackrel{N}{N} \\
\sum_{i}^{0}\end{array}$ & 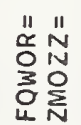 \\
\hline
\end{tabular}

:

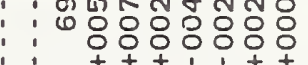
$:$ :

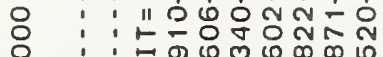
: :

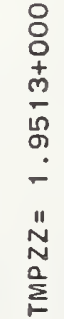

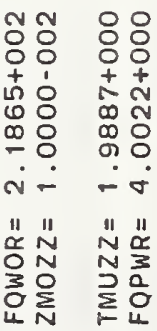
ᄂ

: ำํํㅇํㅇㅇํㅇํㅇํำ

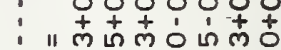

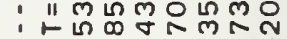

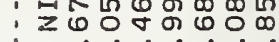
ம்inisio

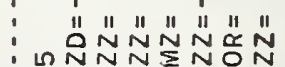

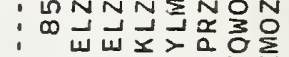
: 1 NNNN : $\frac{11}{2}$

$$
\text { : }
$$

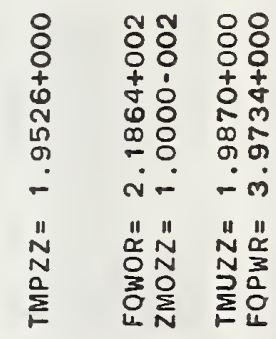

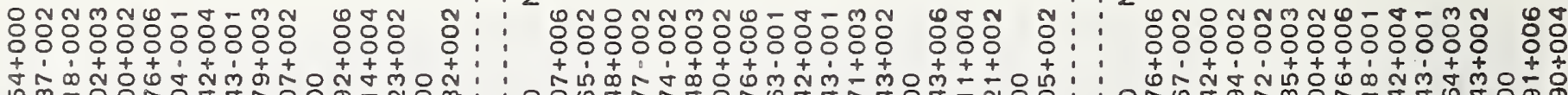

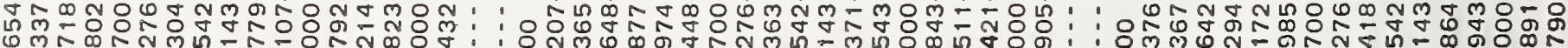

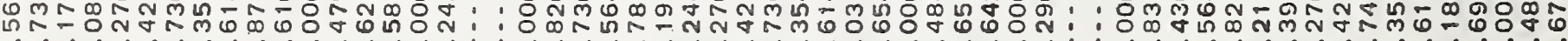
- ம்ंबंरिं

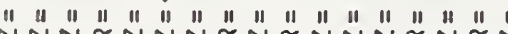
NOJ

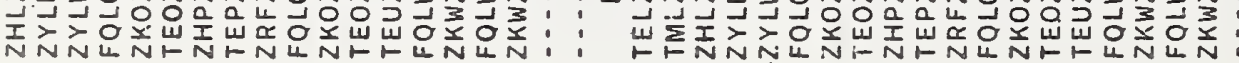

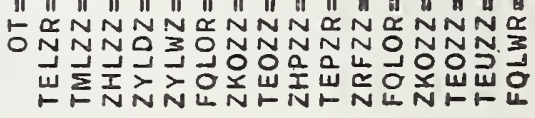

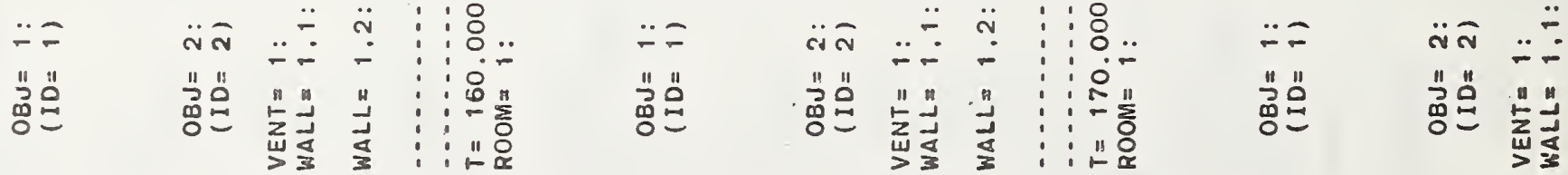




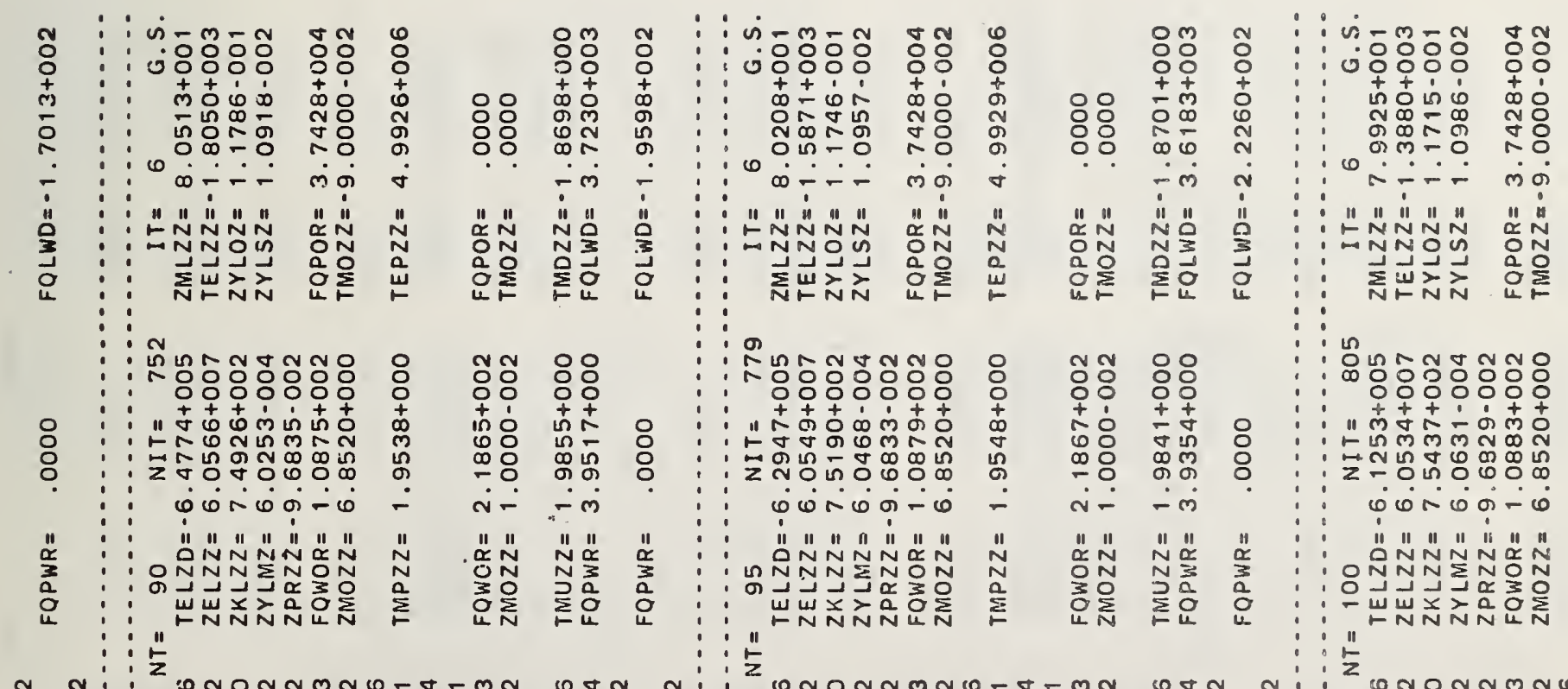

ชี

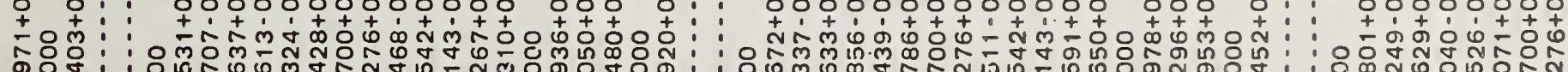

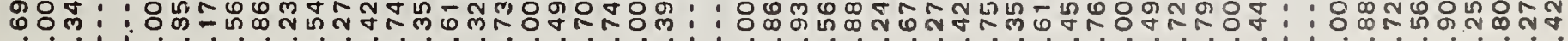

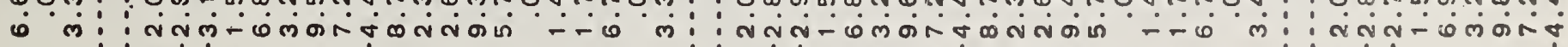
"

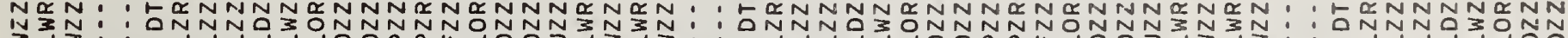

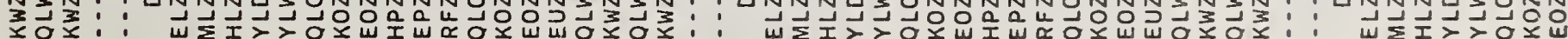
穴员: :

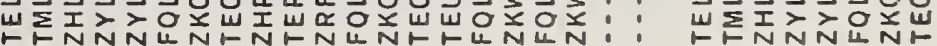

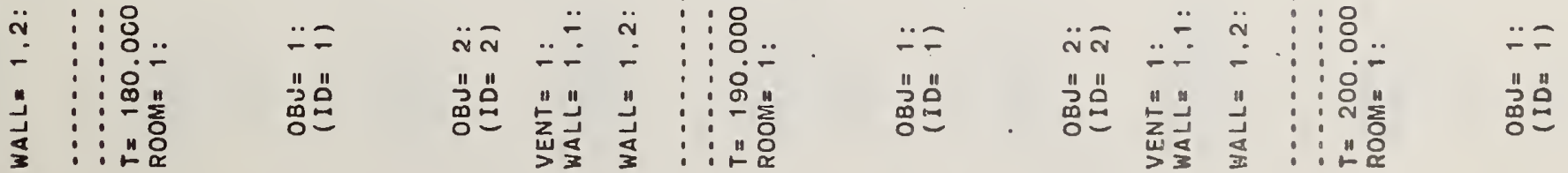




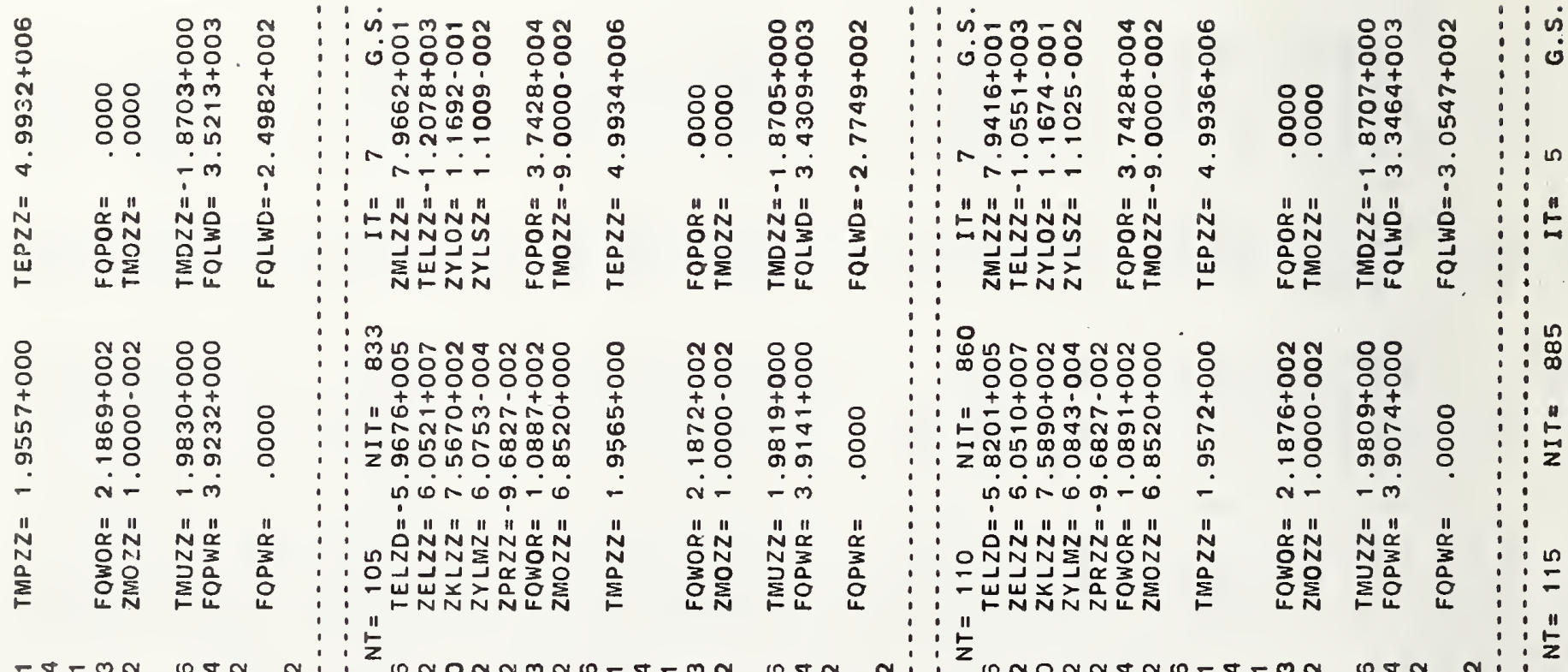

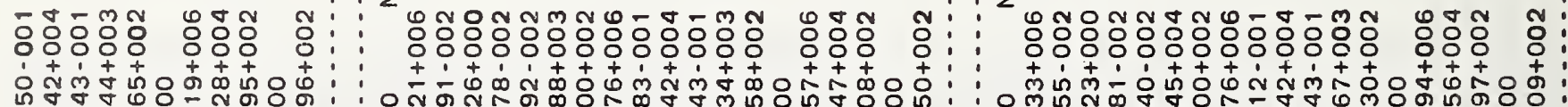

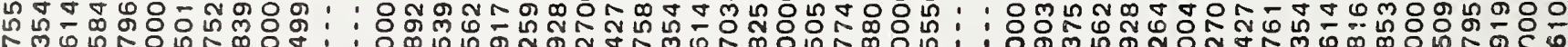

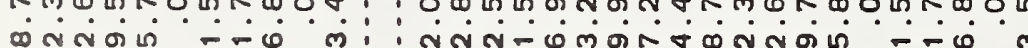

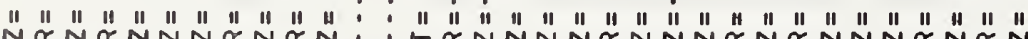

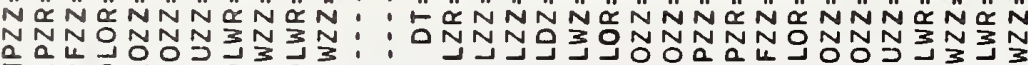

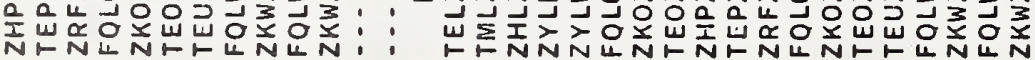

$\dot{i} \dot{0} \dot{0} \cdot \dot{0} \dot{0} \dot{0} \cdot \dot{0} \cdot \dot{0}: \dot{0}$ "I " " " " " " " " " " " " " " " " " " " -

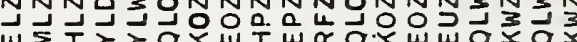

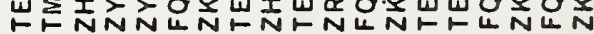

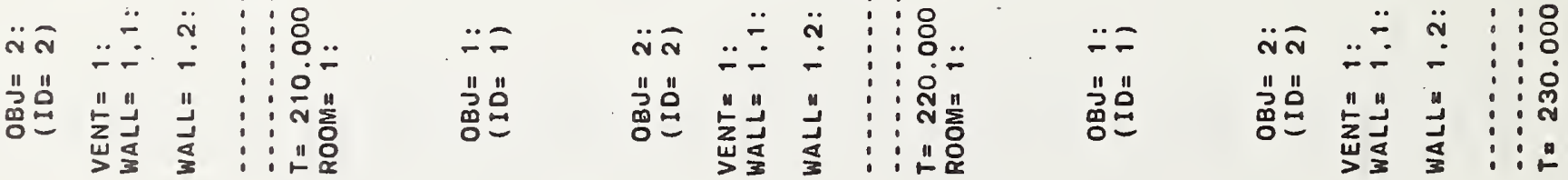




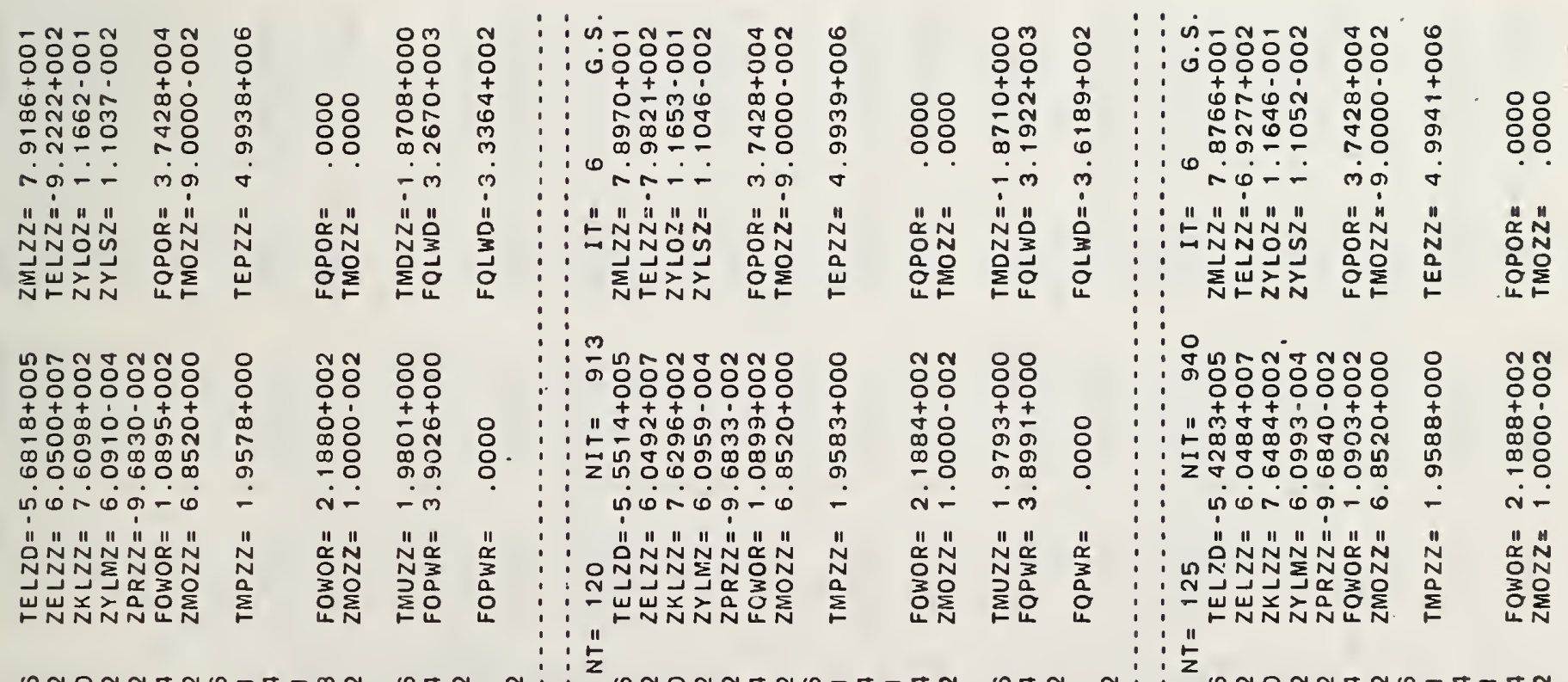

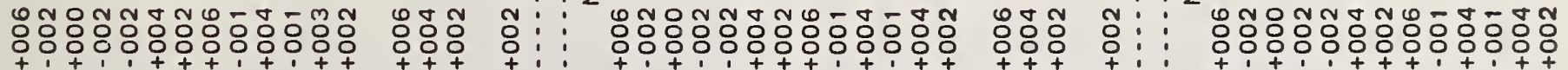

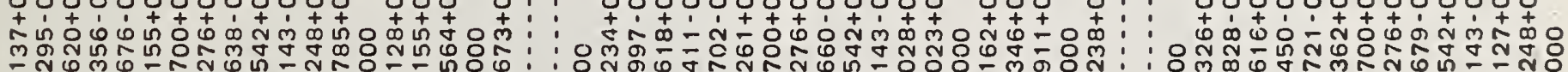

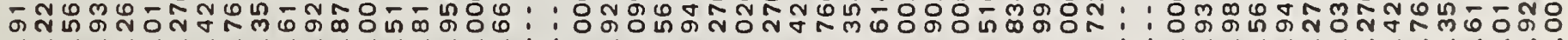

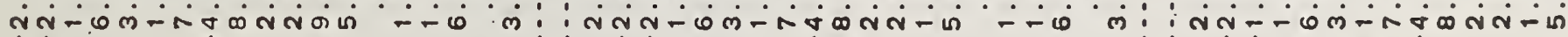

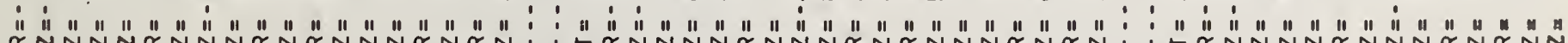

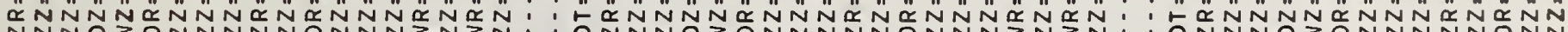

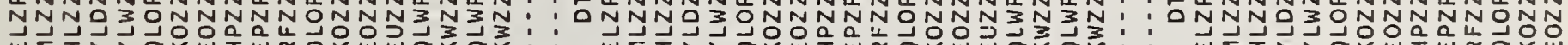

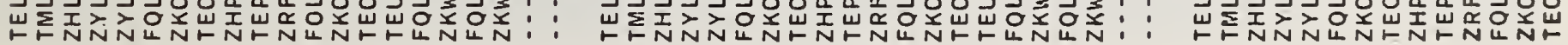

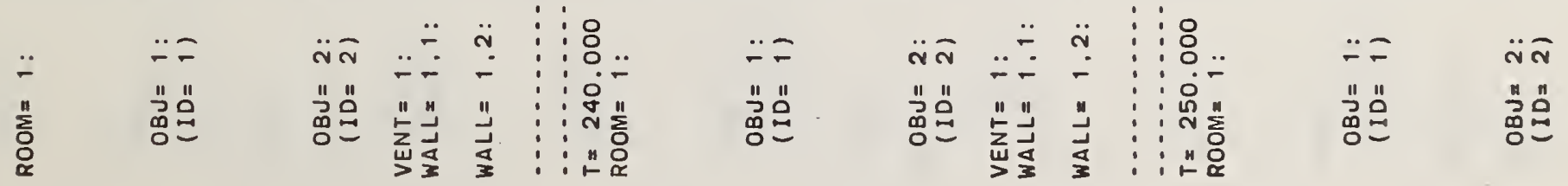



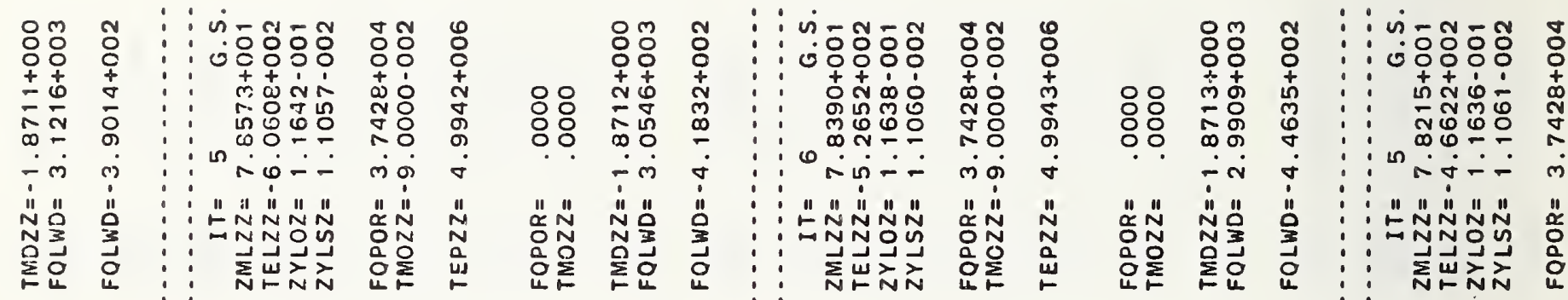

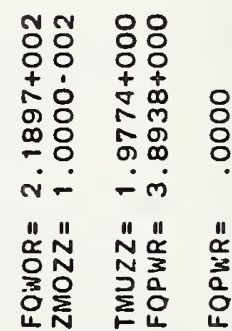

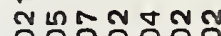

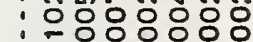

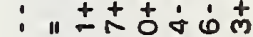
In 능ㅇㅇㅇ요용 $\vdots: \frac{11}{2}$

: : 告

ก 6 - 0 \% -

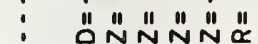
ONNNENO

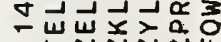
$: \stackrel{11}{2}$

ยี่ำ 00
+

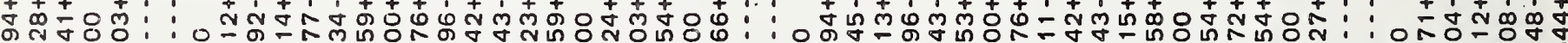

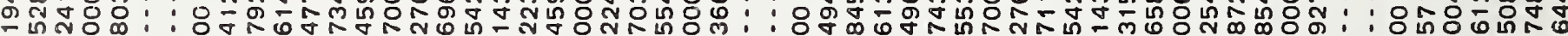

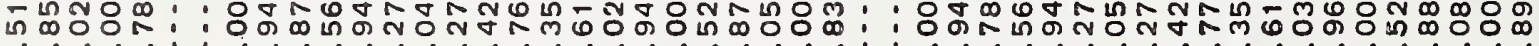

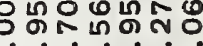

Nin

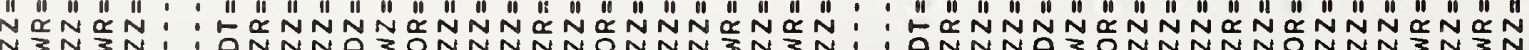

N3N3N: 1 ONNNOSONNNNNONNN

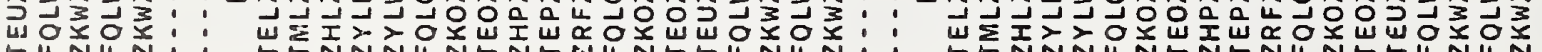

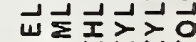

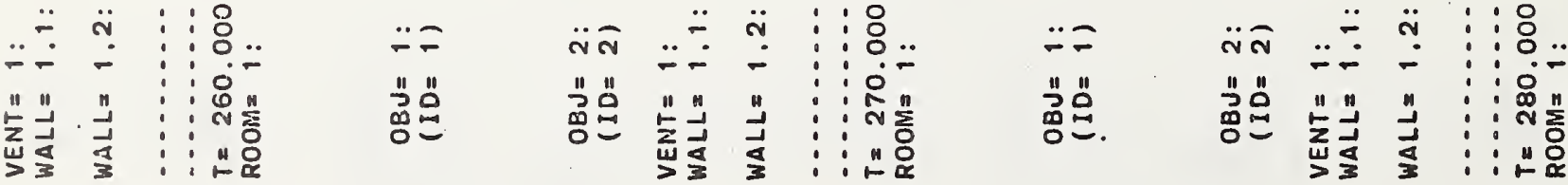



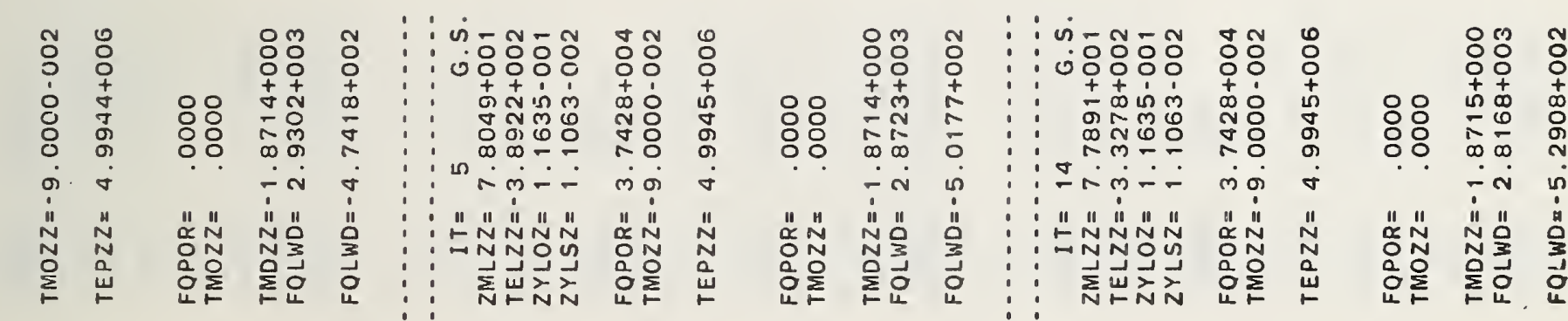

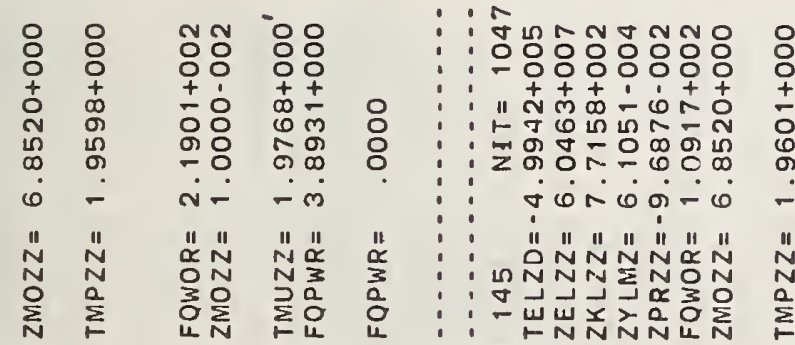

\begin{tabular}{|c|c|}
\hline 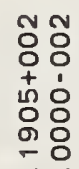 & $\begin{array}{l}\circ \\
0 \\
0 \\
0 \\
+ \\
+ \\
m \\
0 \\
1 \\
1 \\
\sigma \\
\sigma\end{array}$ \\
\hline i - & $-\dot{m}$ \\
\hline & $\stackrel{11}{N}$ \\
\hline
\end{tabular}

$\infty$

: : 응ㅇㅇㅇㅇㅇㅇㅇㅇㅇㅇㅇㅇㅇㅇㅇㅜ

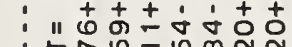

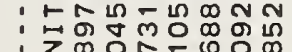

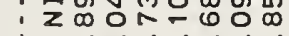
$\dot{\sigma} \dot{0} \dot{0} \dot{0}-\dot{0}$

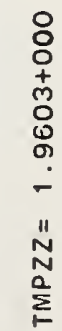

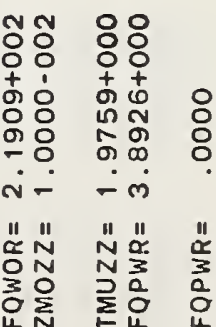
$: \frac{11}{2}$ กำนันกั

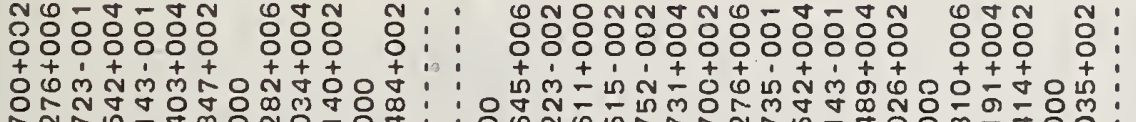
숴슈ำ

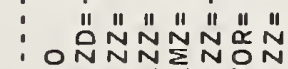
in 107 M

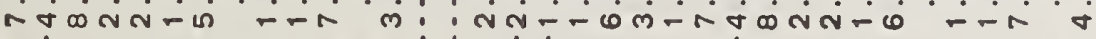

ตก ก ก ก

\section{(2)}

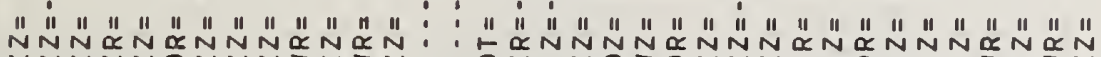

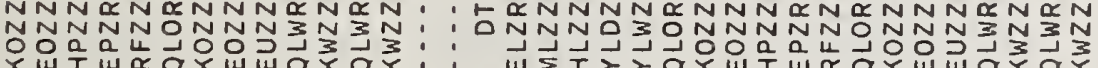

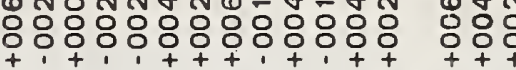

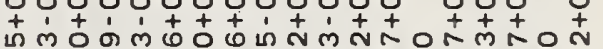
: 듀슨

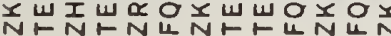

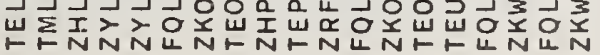

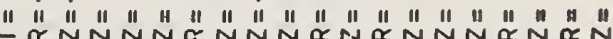

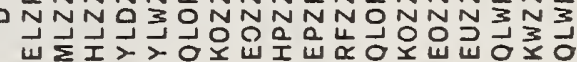

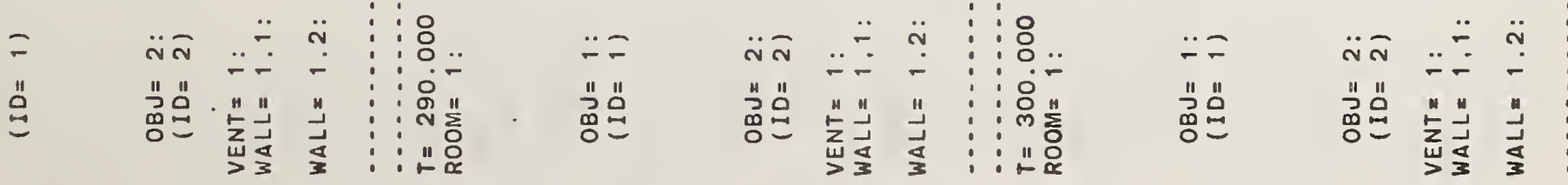




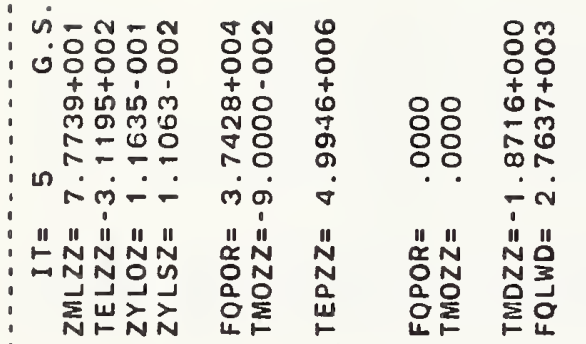
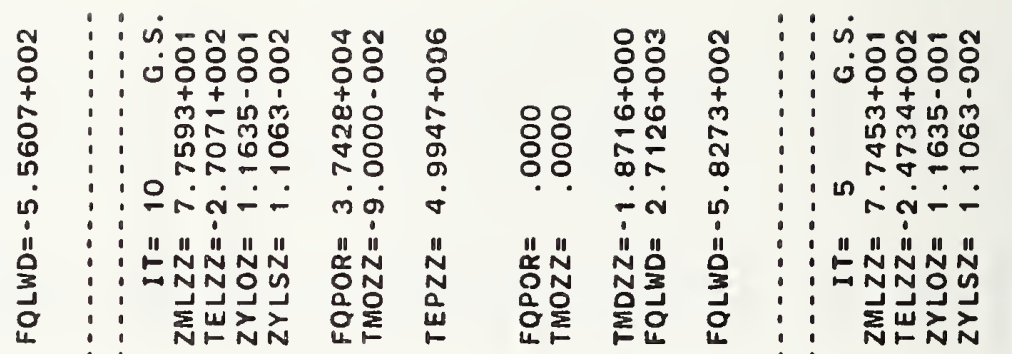

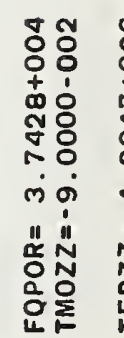

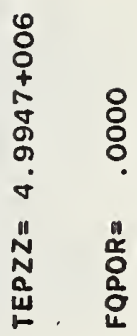

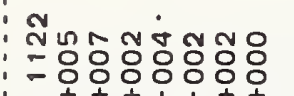

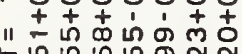

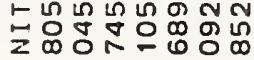

هं $\dot{0} \dot{0}-\dot{0}$

"II II "I II "

กNNNON

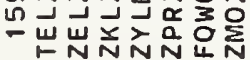

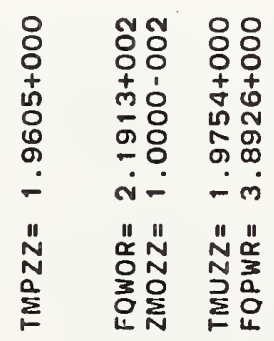

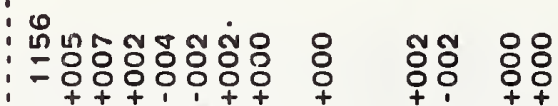

to

I

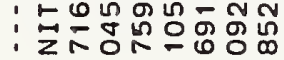

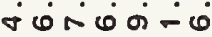

응

ลั่

$\dot{\sim}-\dot{m}$

c

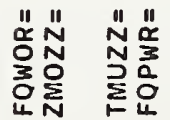

:

。

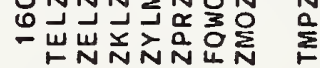

: 㸺

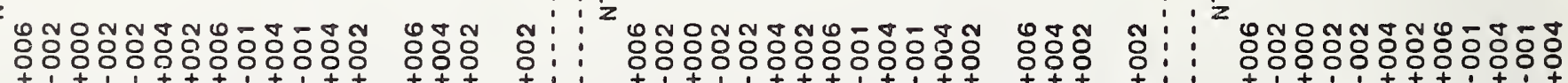

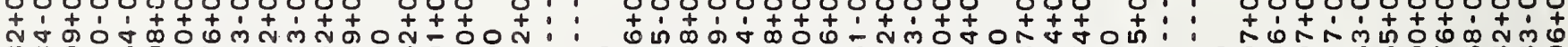
om

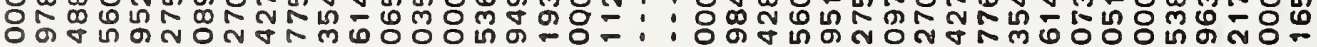

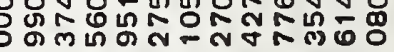
ผ

ง

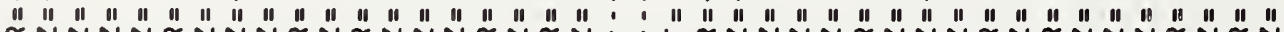

i i II IN

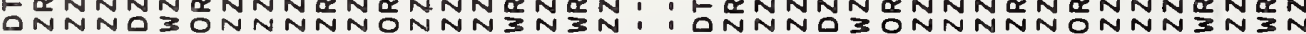

"

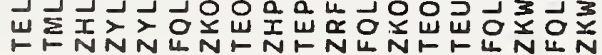

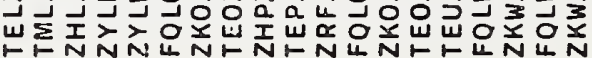

NNNO 30 NNNNNO

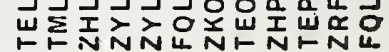

$\frac{2}{20}$

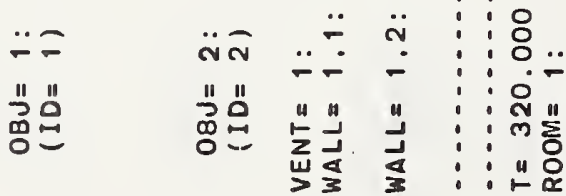

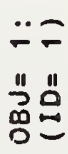

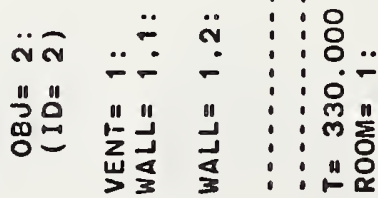

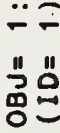

$\ddot{\sim}$ 

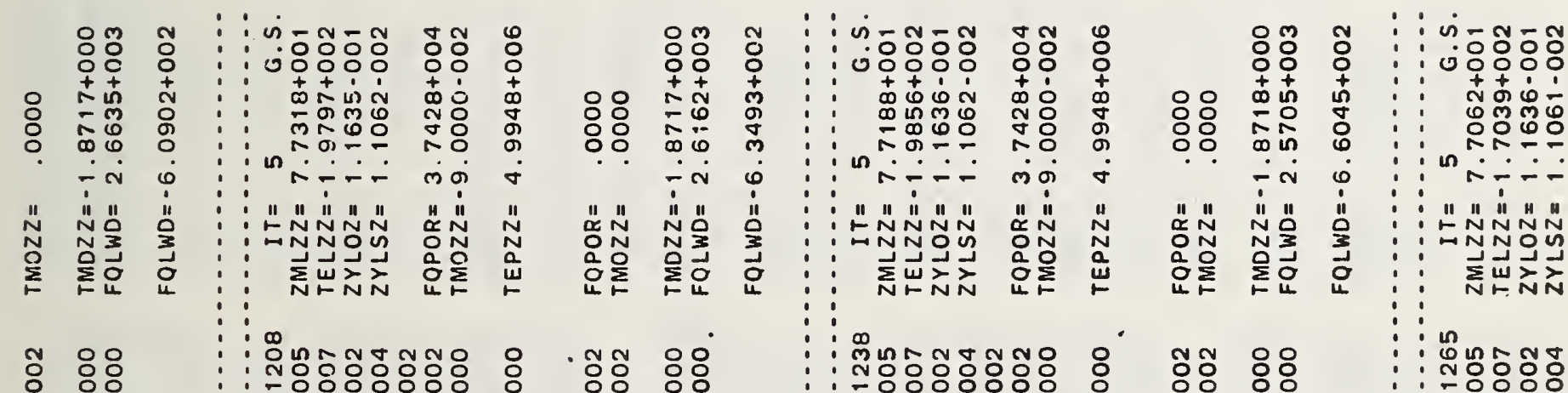

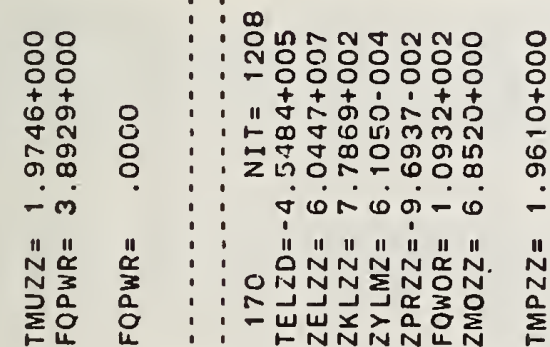
$: \frac{1}{2}$

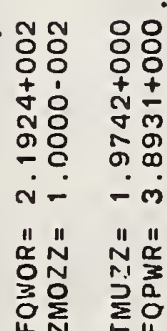

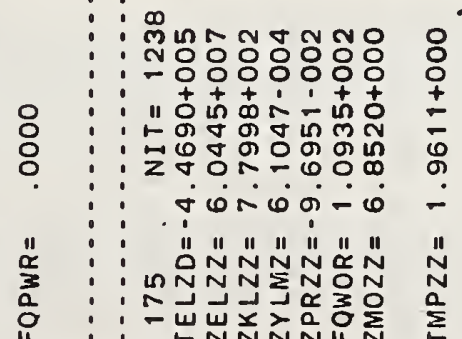

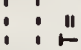

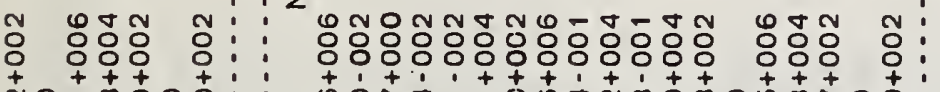
:

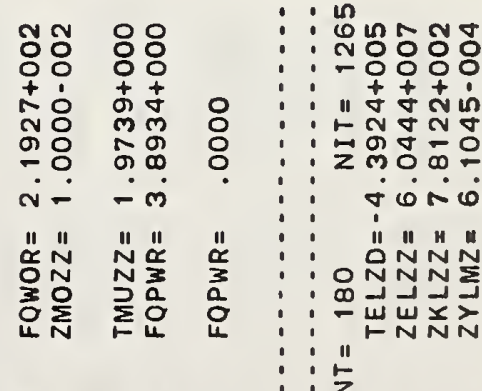

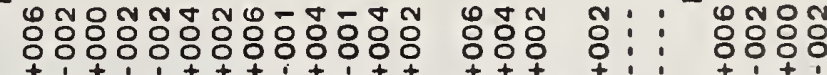

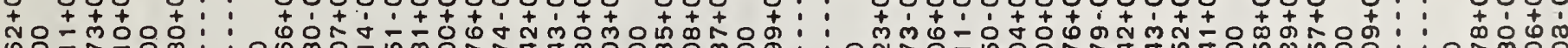

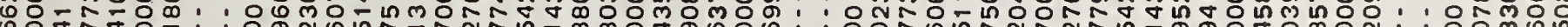

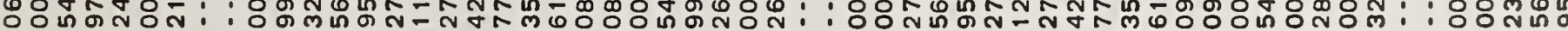

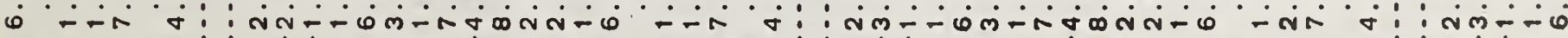
"

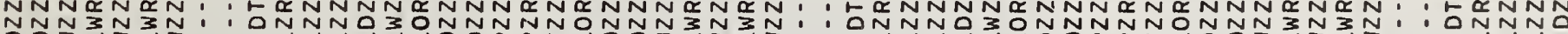

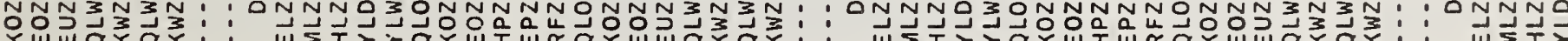

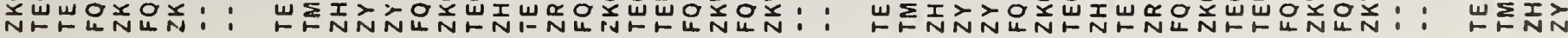

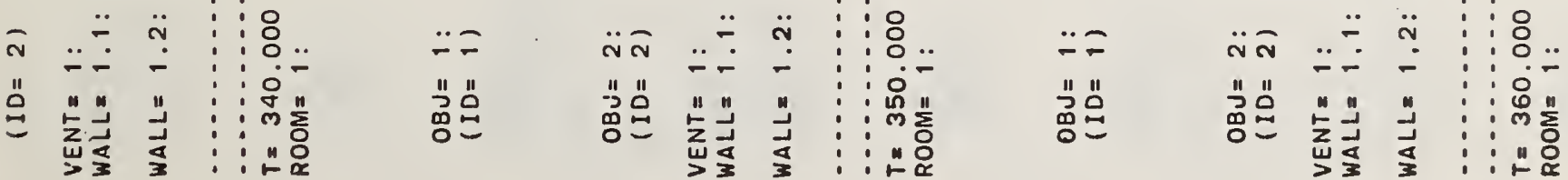




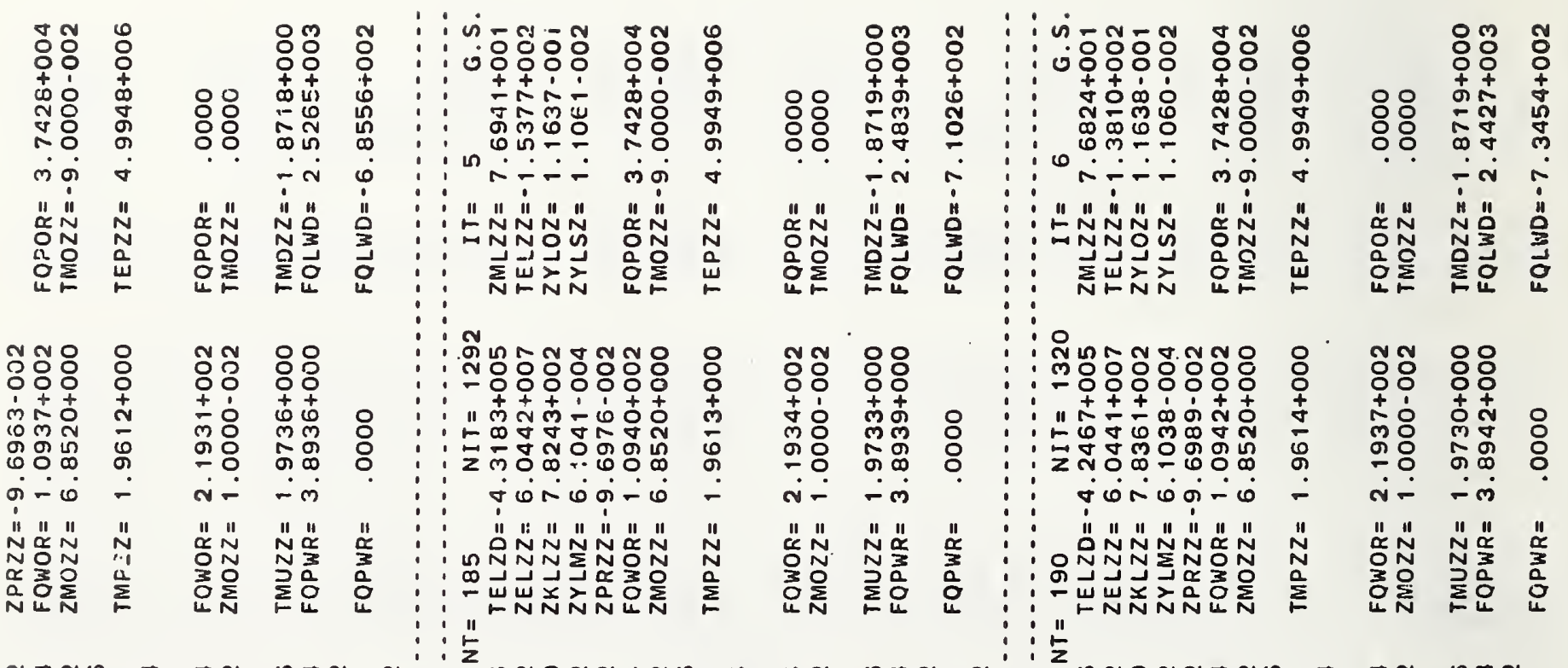

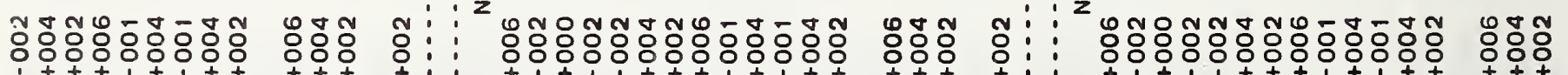

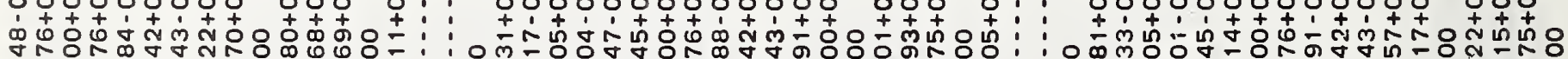

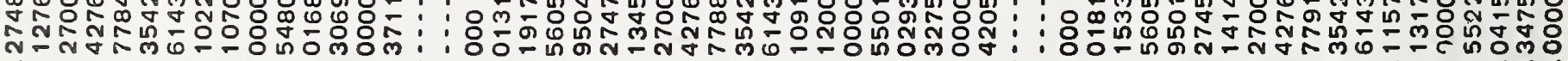

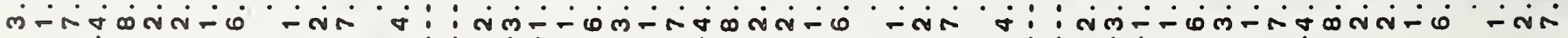

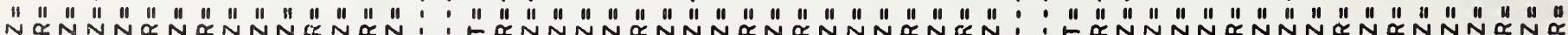

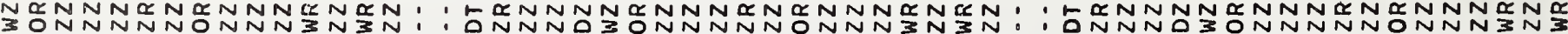

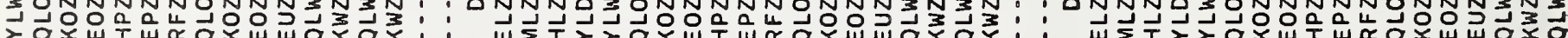

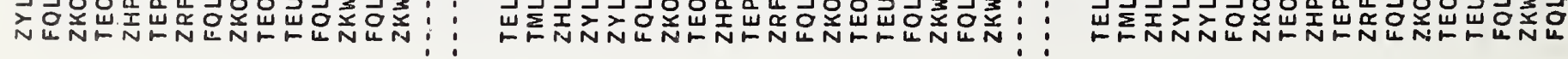

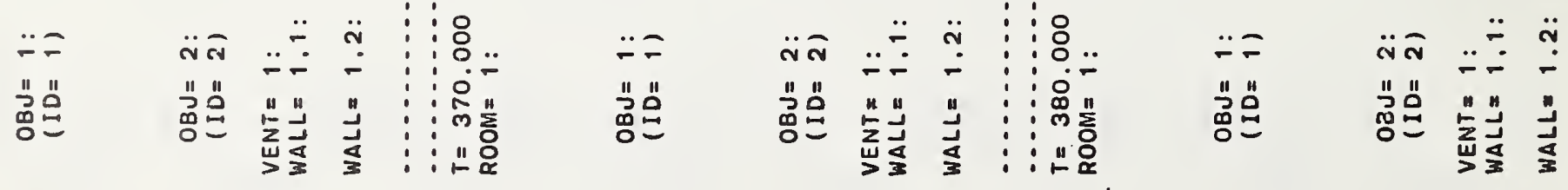




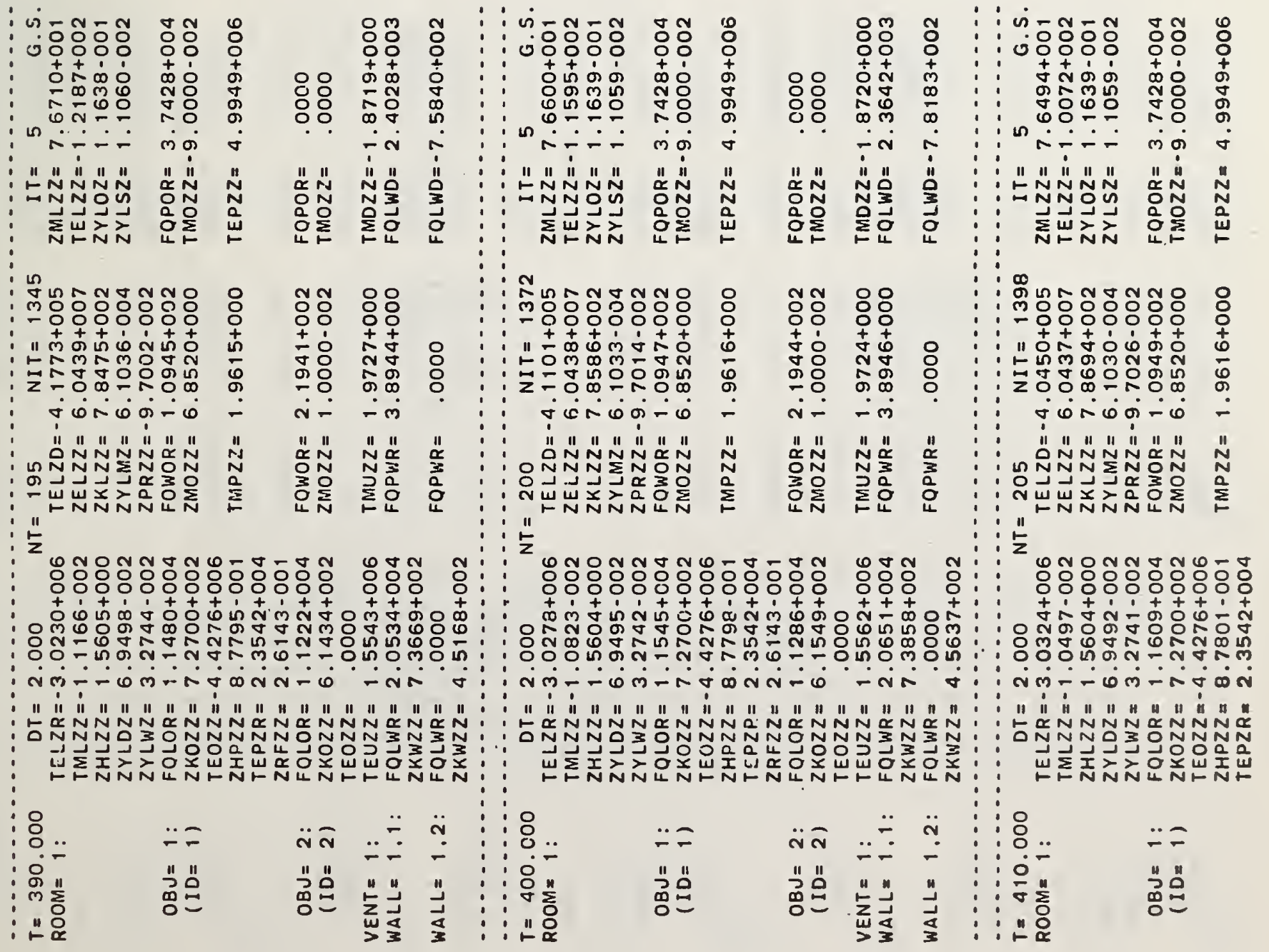




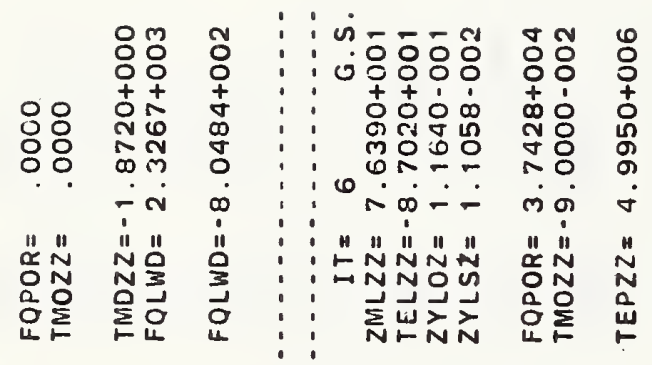
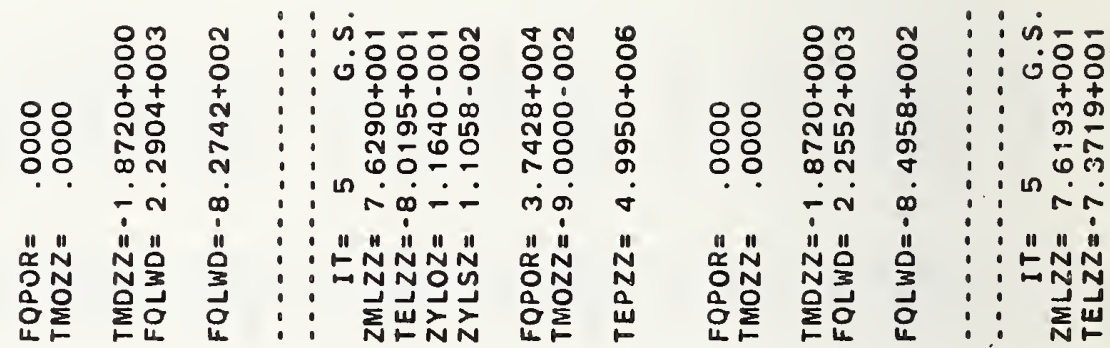

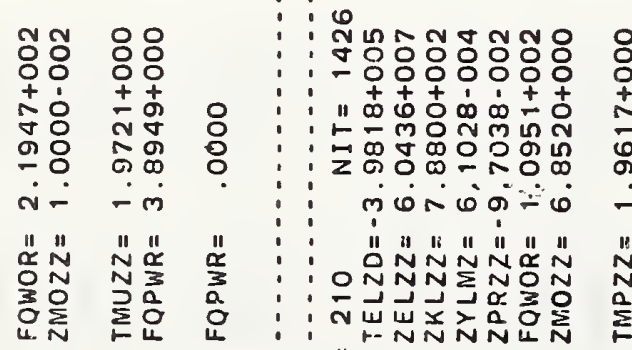

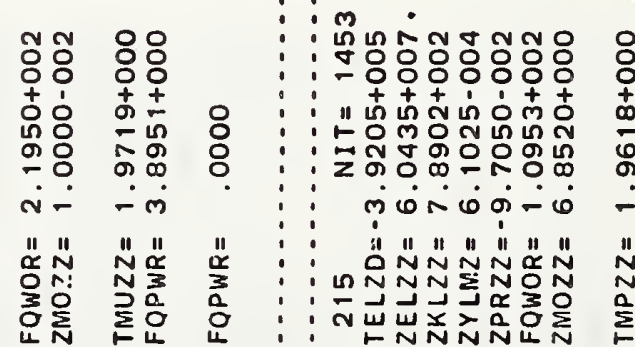
$\vdots: \frac{11}{2}$

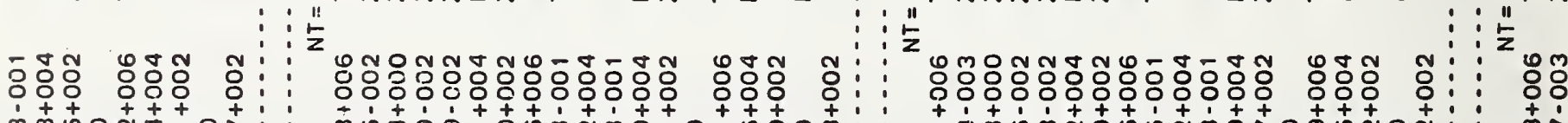

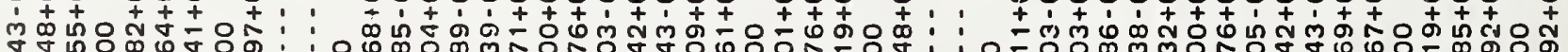

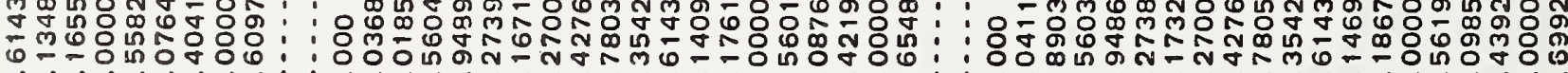

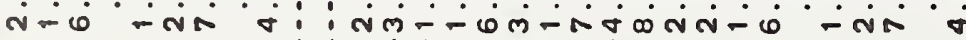

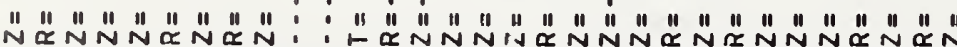

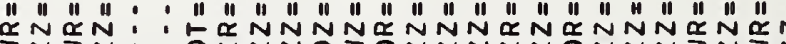
NON N N $3 N 3 N: 10 N N$ N

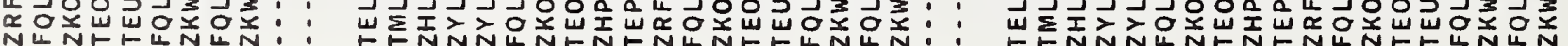

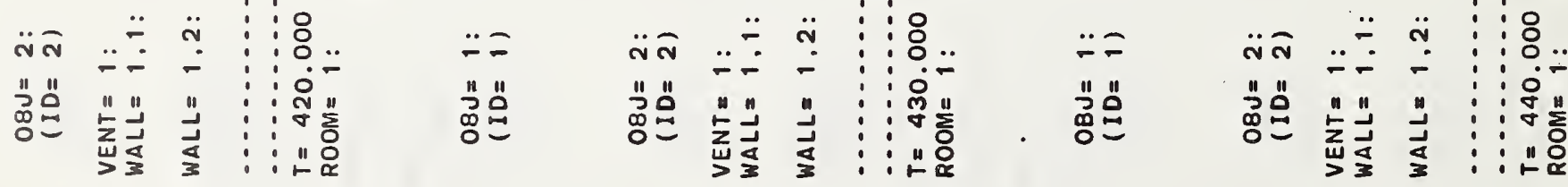




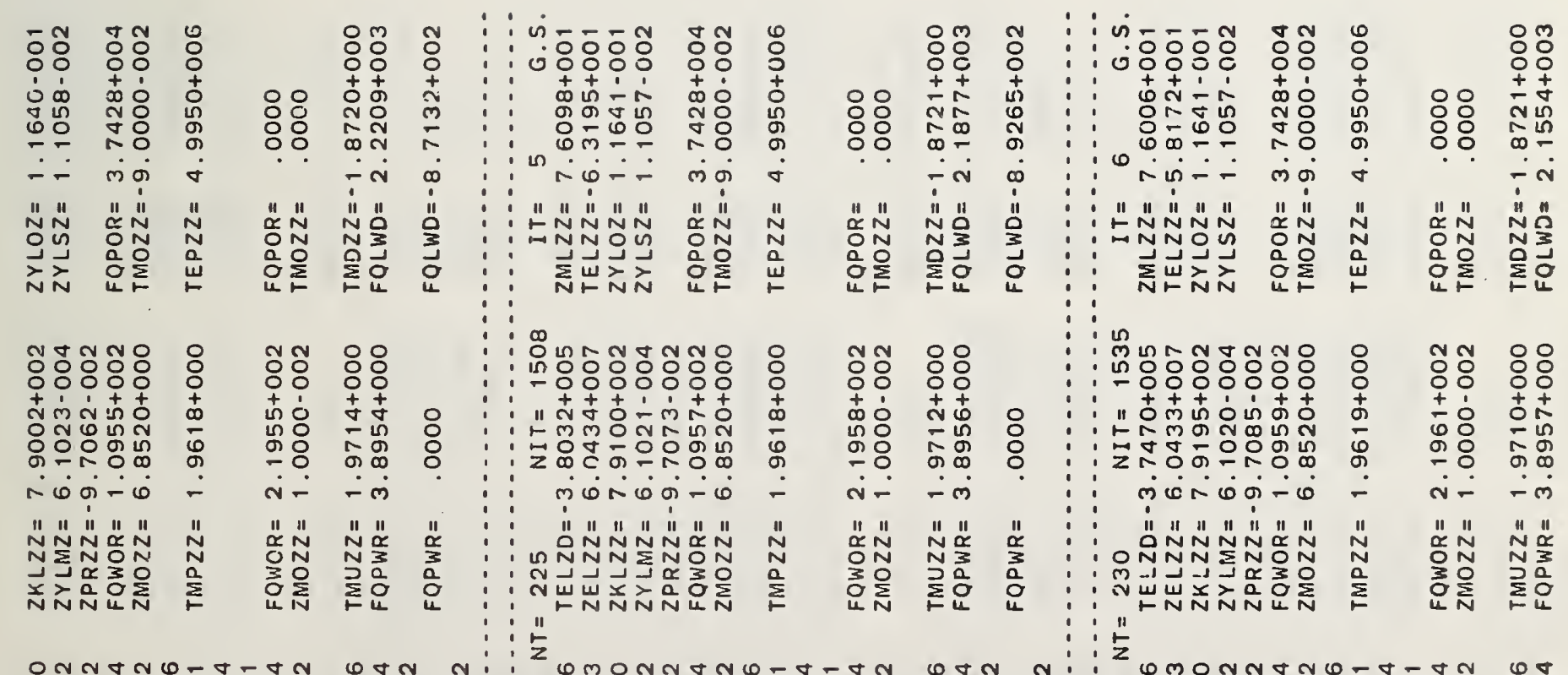

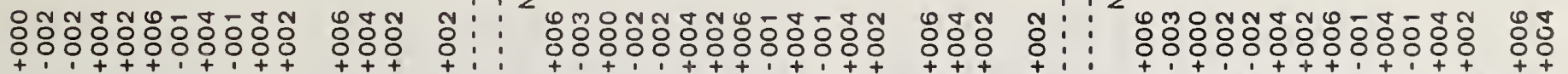

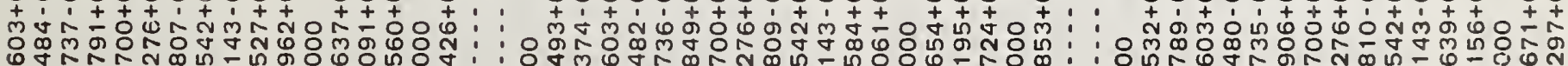

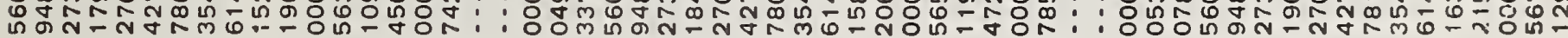

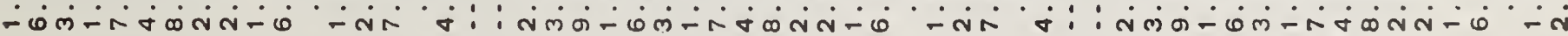
" " " " " " " " " " " " NNN

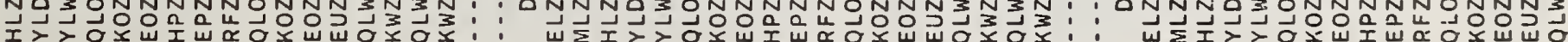

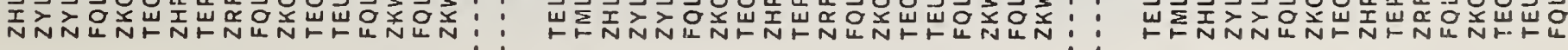

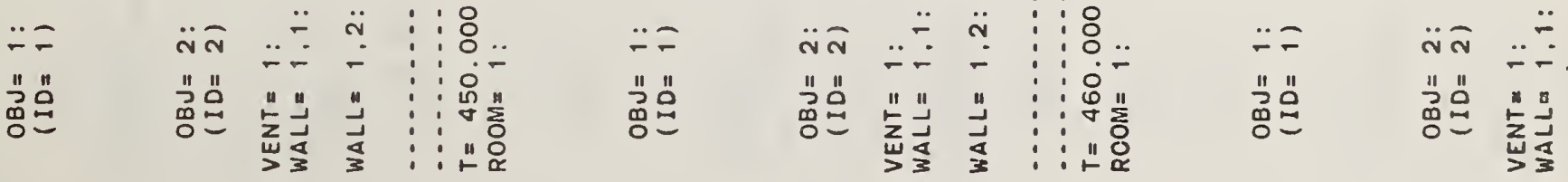




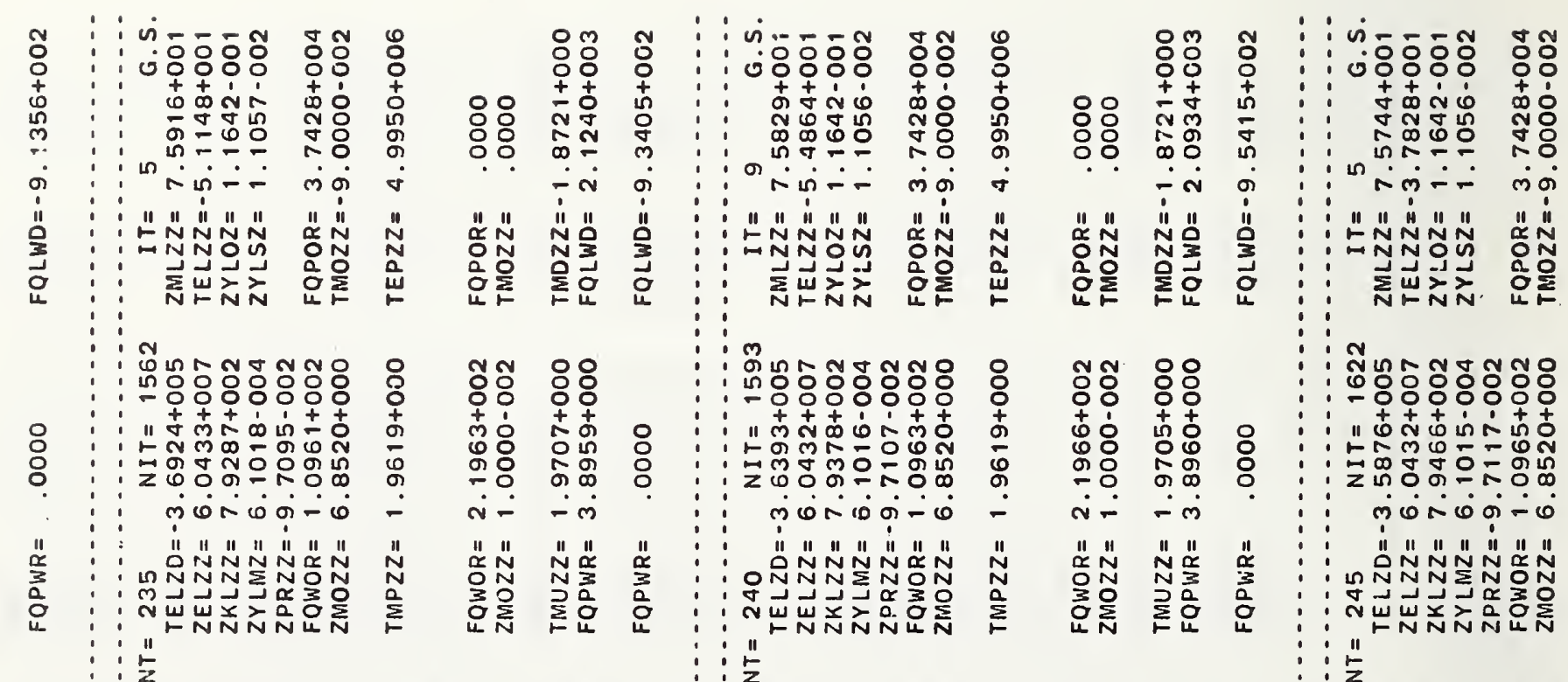

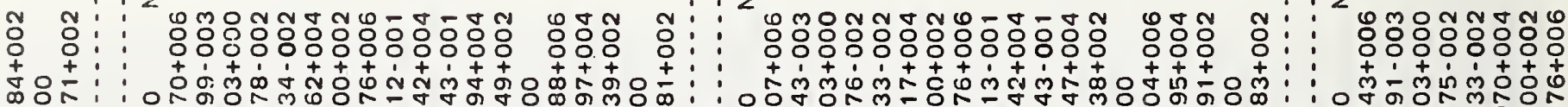

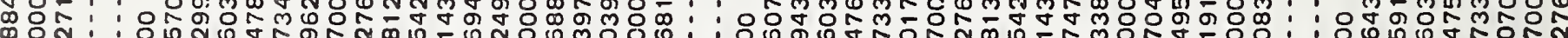

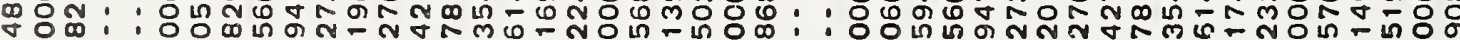

$\therefore-10 \dot{0}$

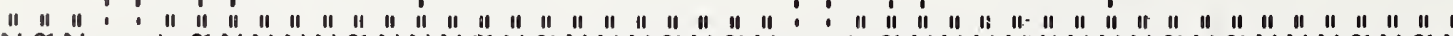

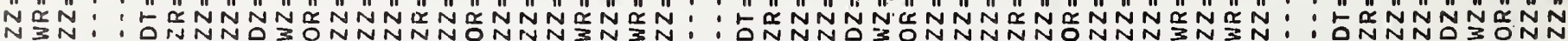

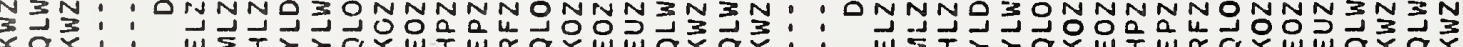

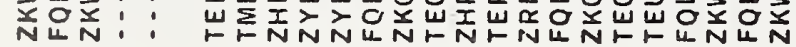

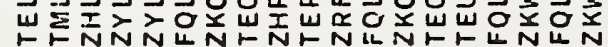

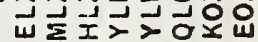

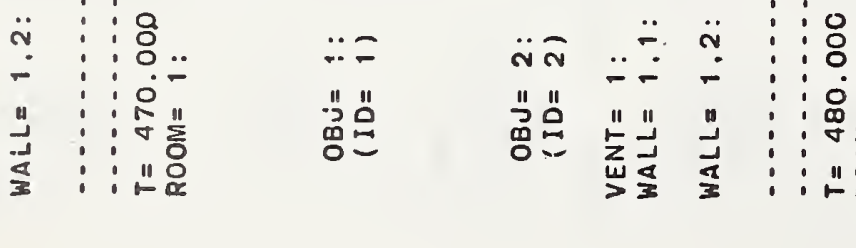



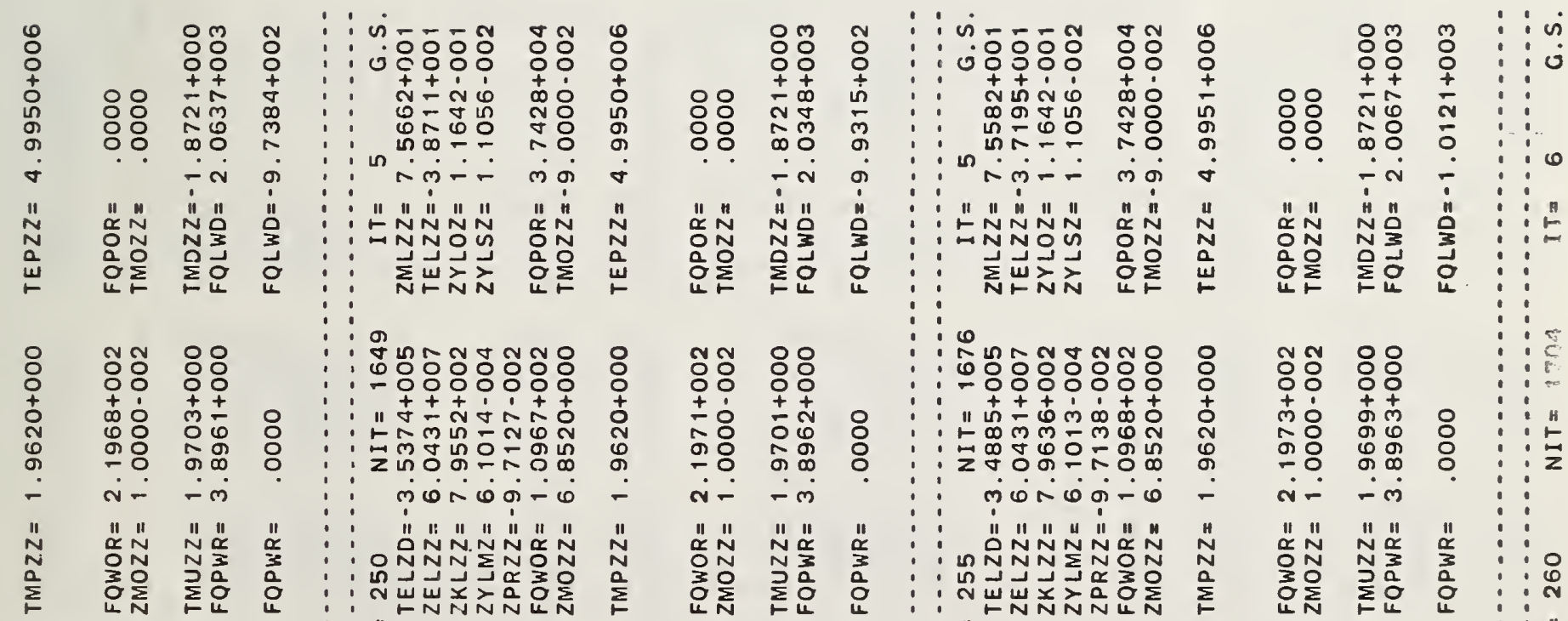
$: \vdots \stackrel{11}{2}$

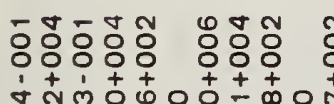
$: \frac{11}{2}$

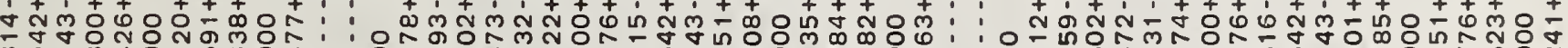
๓

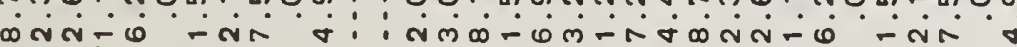

"

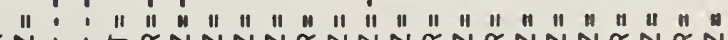

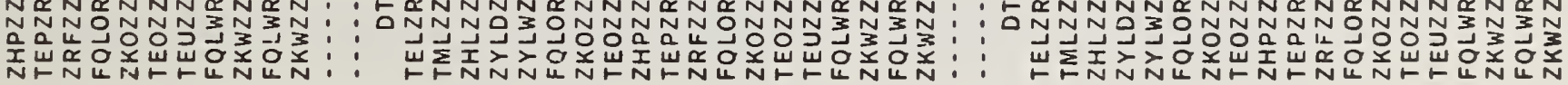

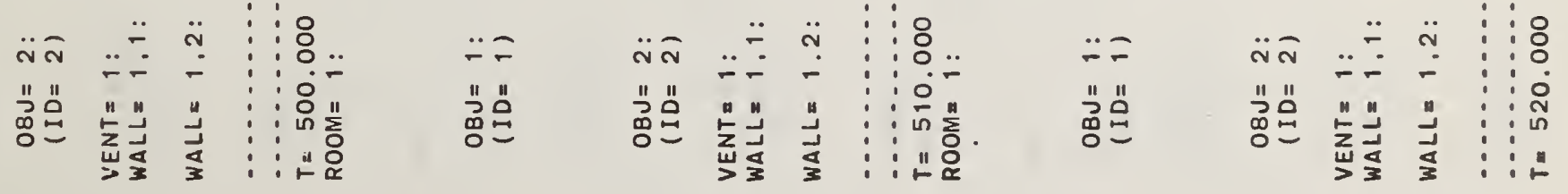



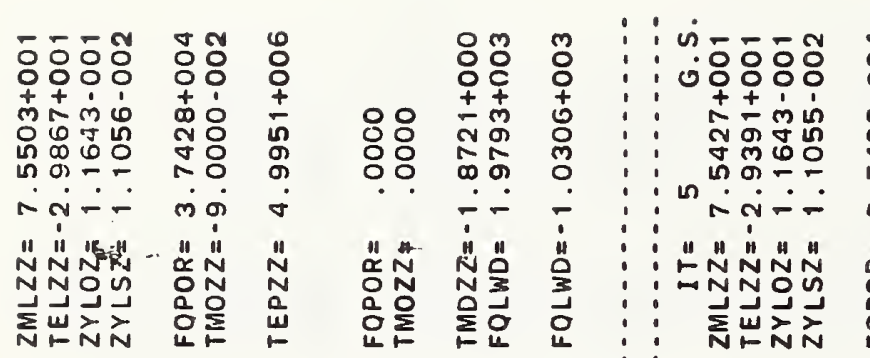

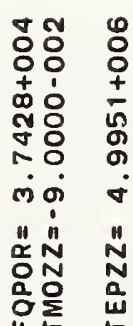
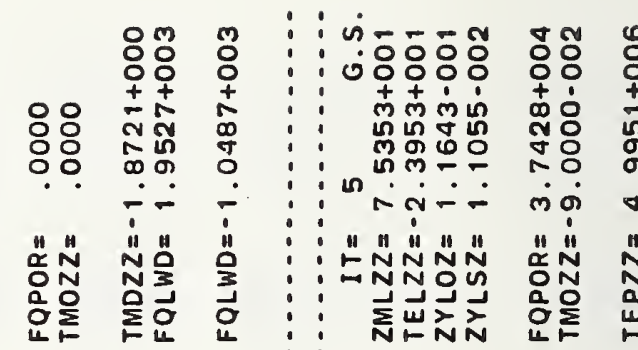

:ঃ

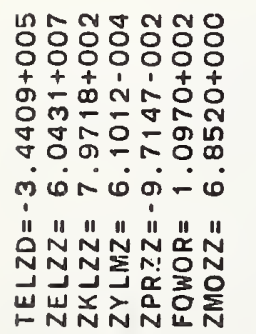

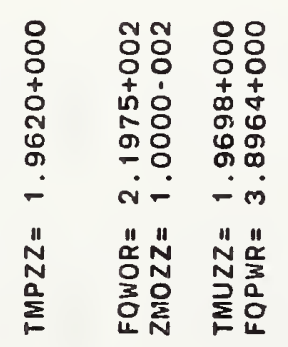

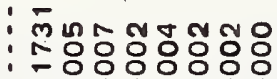

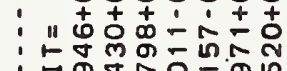

:

mंN $\dot{0} 0-0$

:

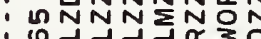

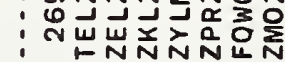

:

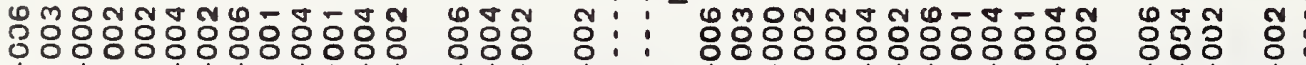

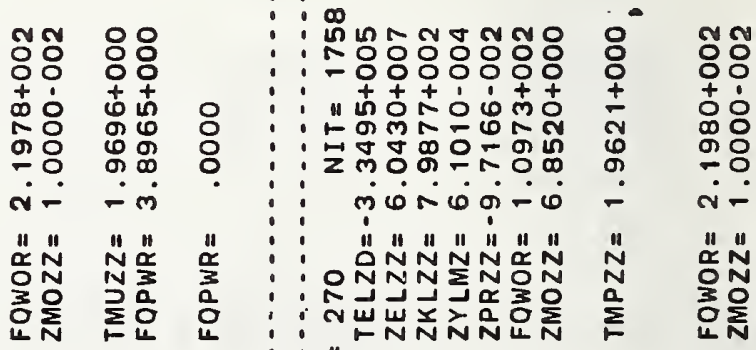
$: \frac{11}{2}$

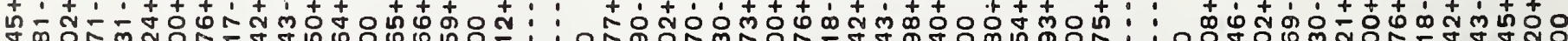

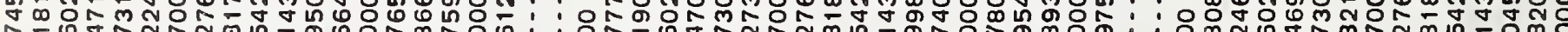
ㄷำ

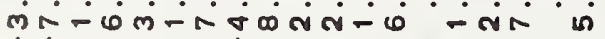

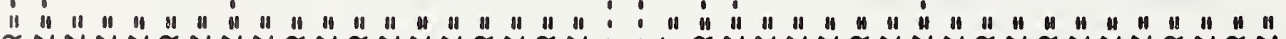
政

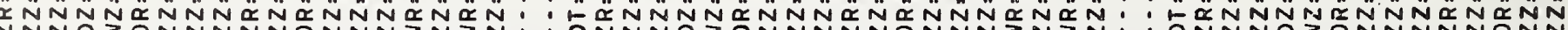
NNOZONNNNNONNNZNIN: DNNNOZONNNNNONNNIN3N

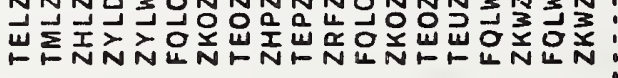
NNOZONNNNNONN

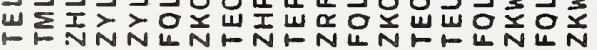

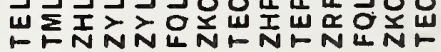

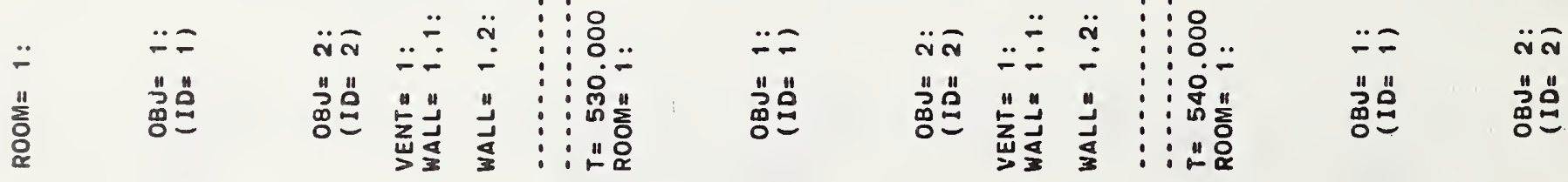




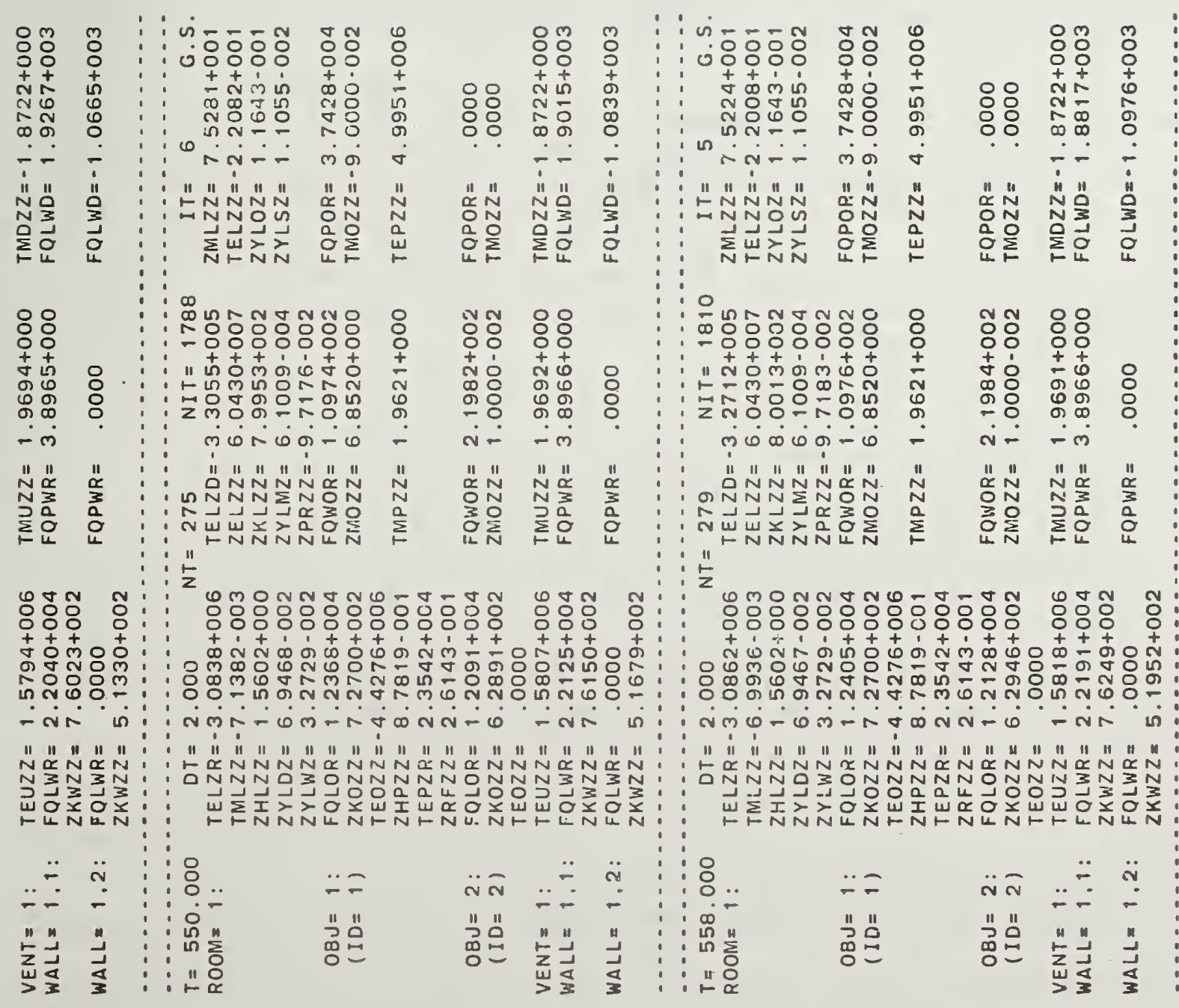


NBS-114A (REV. 2.80)

U.S. DEPT. OF COMM.

1. PUBLICATION OR REPORT NO. NBSIR 82-2516
2. Performing Organ. Report No.?

3. Publication Date

May 1982

SHEET (See instructions)

4. TITLE AND SUBTITLE

COMPUTER FIRE MODELING FOR THE PREDICTION OF FLASHOVER

5. AUTHOR(S)

R.D. Peacock and J.N. Breese

6. PERFORMING ORGANIZATION (If joint or other than NBS, see instructions)

NATIONAL BUREAU OF STANDARDS

DEPARTMENT OF COMMERCE

WASHINGTON, D.C. 20234

9. SPONSORING ORGANIZATION NAME AND COMPLETE ADDRESS (Street, City, Stote, ZIP)

7. Contract/Grant No.

U. S. Department of Health and Human Services

Washington, DC 20203

10. SUPPLEMENTARY NOTES

Document describes a computer program; SF-185, FIPS Software Summary, is attached.

11. ABSTRACT (A 200-word or less factual summary of most significant information. If document includes a significant bibliography or literature survey, mention it here)

This study presents an initial look at the potential for the use of fire growth models. A technique is presented, based upon numerous fire growth predictions, to estimate the minimum energy required to produce temperature levels capable of promoting flashover in a variety of room configurations. The parameters investigated included room size, room ventilation, ceiling height and room lining material. A comparison is presented of the predictions made with available full-scale fire test data and with other predictions. The technique, although needing refinement, shows promise

to estimate flashover potential.

12. KEY WORDS (Six to twelve entries; alphabetical order; capitalize only proper names; and separate key words by semicolons) Compartment fires; computers; fire growth; flashover; mathematical models.

14. NO. OF PRINTED PAGES

\section{8}

15. Price

$\$ 10.50$ 
